\title{
Componente de Controle Transacional para Integração Assíncrona de Bases de Dados
}

Marcelo Camacho de Souza

\author{
DISSERTAÇÃO APRESENTADA \\ $\mathrm{AO}$ \\ INSTITUTO DE MATEMÁTICA E ESTATÍSTICA \\ DA \\ UNIVERSIDADE DE SÃO PAULO \\ PARA \\ OBTENÇÃO DO TÍTULO DE MESTRE \\ EM \\ CIÊNCIAS DA COMPUTAÇÃO
}

Área de Concentração: Ciências da Computação / MAC

Orientador: Prof. Dr. João Eduardo Ferreira 


\section{Componente de Controle Transacional para Integração Assíncrona de Bases de Dados}

Este exemplar corresponde à redação final da dissetação devidamente corrigida e defendida por Marcelo Camacho de Souza e aprovada pela comissão julgadora.

São Paulo, 05 de fevereiro de 2003.

Banca examinadora:

- Prof. Dr. João Eduardo Ferreira (orientador) (IME-USP)

- Prof. Dr. Francisco Carlos da Rocha Reverbel (IME-USP)

- Prof. Dr. Calton Pu (Georgia Tech) 


\section{Agradecimentos}

Depois de muito trabalho e dedicação, finalizo com esta dissertação mais um importante passo na minha carreira acadêmica e profissional. Para viabilizar esse sonho tive o apoio, a compreensão e o auxílio de muitas pessoas que muito me incentivaram e que são muito importantes para a minha vida.

Inicialmente gostaria de agradecer à minha família, em especial à minha esposa Silviara e aos meus filhos Gabriel e Felipe, pela paciência e compreensão por causa dos longos períodos de separação. Agradeço também aos meus pais e irmãos pelo caráter e formação que me proporcionaram. Obrigado a Magali e Rogério pelos anos de convivência e a enorme dedicação nos estudos.

Um agradecimento especial ao meu orientador, Prof. Dr. João Eduardo Ferreira, pela oportunidade oferecida e pela confiança e amizade em mim depositada e a infraestrutura disponibilizada pelo laboratório de banco de dados do IME-USP. Agradeço também aos professores do Instituto de Matemática e Estatística (IME) pela convivência e seriedade profissional, e à Universidade de São Paulo (USP) pela estrutura e pelos recursos compartilhados.

Gostaria de agradecer ainda aos amigos de Ribeirão Preto, da Unesp-Rio Claro, do trabalho e da USP pelos momentos felizes e revigorantes durante todos esses anos de convivênvia.

E, por fim, e sem menos tardar, agradeço a Deus pelas oportunidades a mim oferecidas e às bênçãos alcançadas. 


\section{Resumo}

O advento da computação móvel e o uso de bancos de dados autônomos têm suprido a crescente demanda de recursos computacionais para apoio às bases de dados assíncronas. Mesmo em condições de isolamento de comunicação, os bancos de dados autônomos permitem a comunicação entre os dados por meio de armazenamento de cópias de dados locais, as quais foram obtidas previamente por processos de replicação de dados.

Em relação a essa cópia local são permitidas operações de leitura e escrita sobre os dados. Essas operações devem ser repassadas às demais instâncias de banco de dados. Nos ambientes tradicionais também existem justificativas para o uso de banco de dados autônomo.

Um exemplo é o incremento da segurança para possíveis falhas de comunicação entre as instâncias dos bancos de dados. Em tais ocorrências de falhas de comunicação, o acesso ao banco de dados torna-se local para registro das transações pendentes. As transações registradas são propagadas para as demais instâncias após o restabelecimento da comunicação.

Nossa proposta apresenta uma alternativa para a utilização de instâncias de bases de dados, de modo a permitir a integração de transações conflitantes realizadas sobre réplicas de dados. Este trabalho tem como hipótese de solução a parametrização de transações, de acordo com o conjunto de regras do domínio de aplicação, para diminuir o conflito entre transações postergadas. 


\begin{abstract}
The advent of the mobile computer and the usage of autonomous database systems have supplied the expanding computational resources demand for accessing asynchronous database systems. Even in communication isolation conditions the autonomous database systems permit communication between data through storage of local data copy which were got previously by a data replication process.

Read and write operations on the database are permitted on this local copy. These operations must be passed on to other database instances. There are also justifications in the traditional environment for the usage of the autonomous database.

An example is the security increment for the possible communication failures between the database instances. In such communication failure occurrences, the database access becomes local for registering of the pending transactions. The registered transactions are propagated to other instances after the re-establishing of communication.

Our research presents an alternative for usage of database instances to integrate transactions accomplished on replied data. This work presents solution hypothesis through the transaction parametrization, according the application domain rules, to reduce the conflicts between postponed transactions.
\end{abstract}




\section{Sumário}

1. Introdução

1.1. Descrição

1.2. Delimitação e caracterização do problema

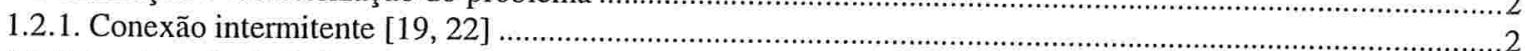

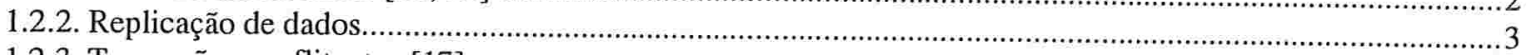

1.2.3. Transações conflitantes [17]

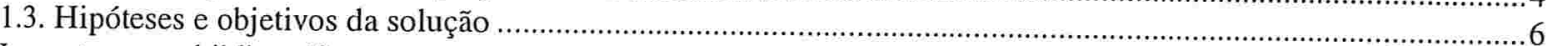

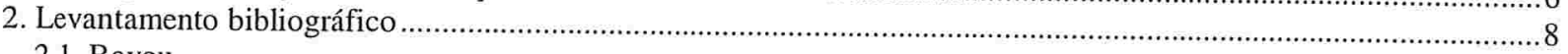

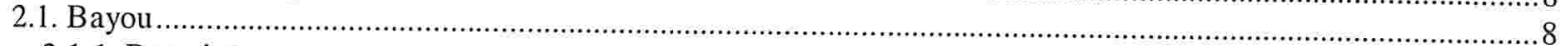

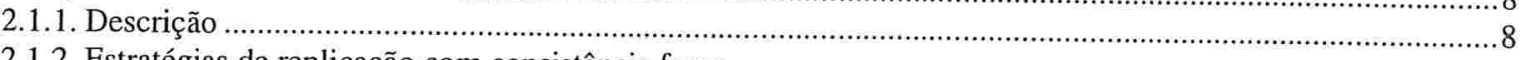

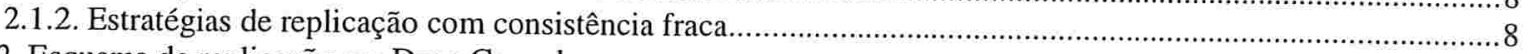

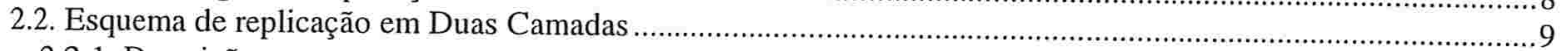

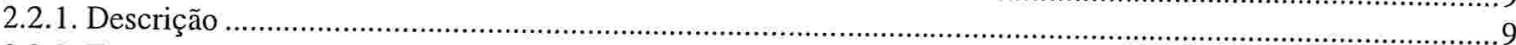

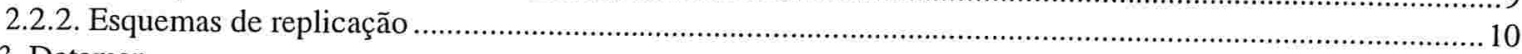

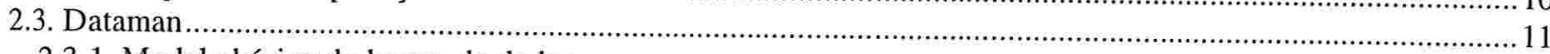

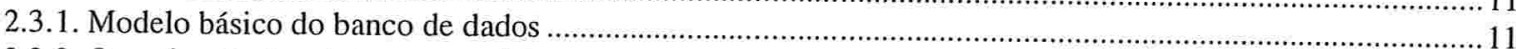

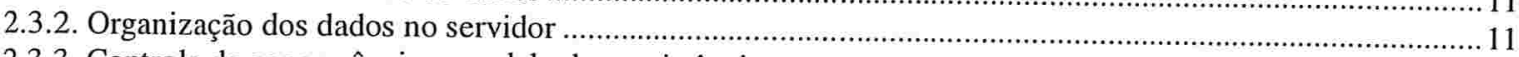

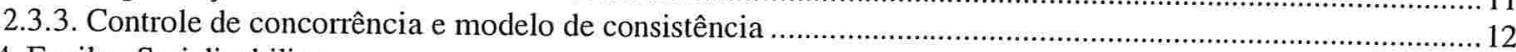

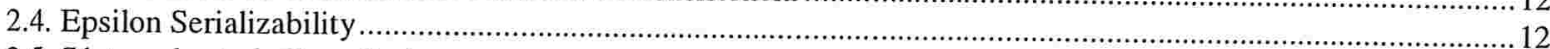

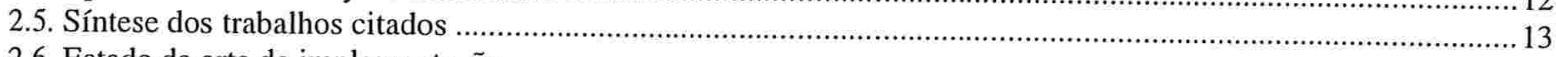

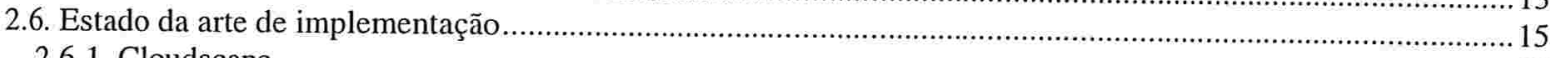

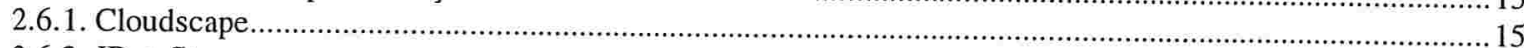

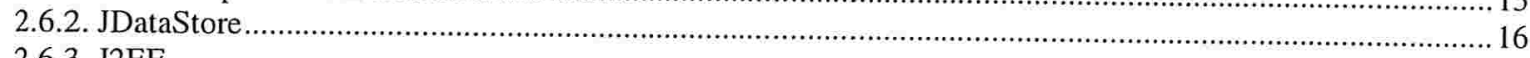

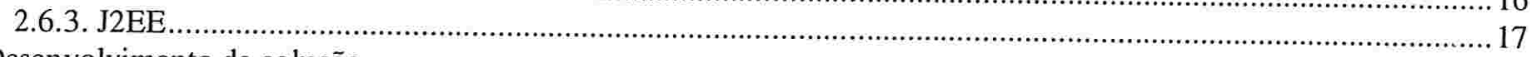

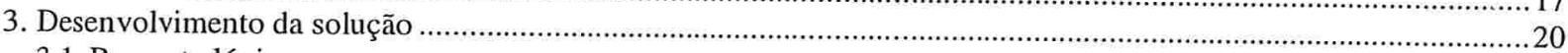

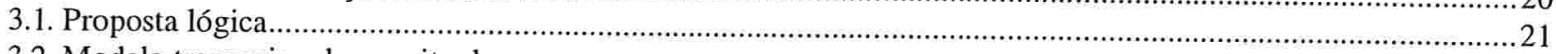

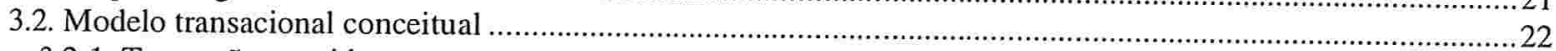

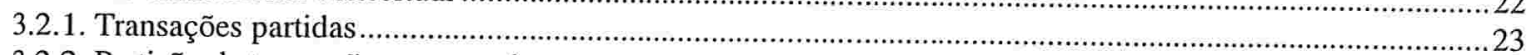

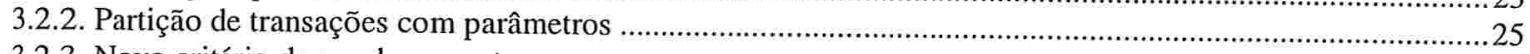

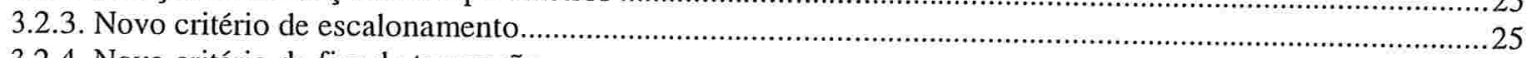

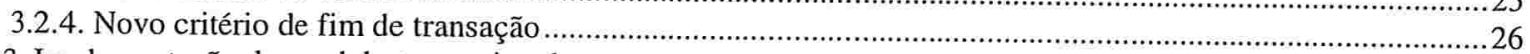

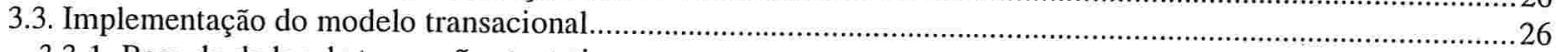

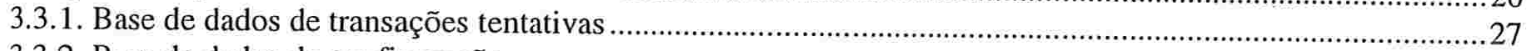

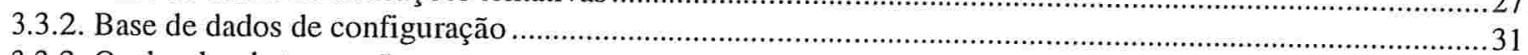

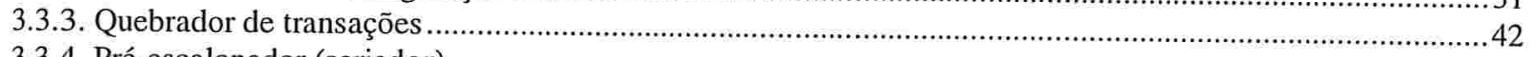

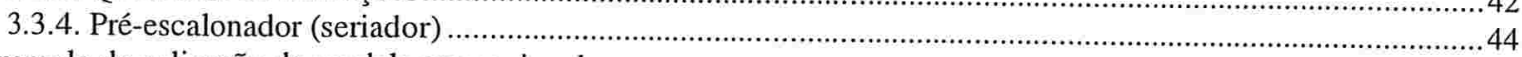

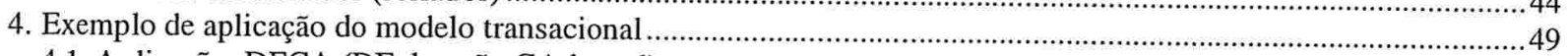

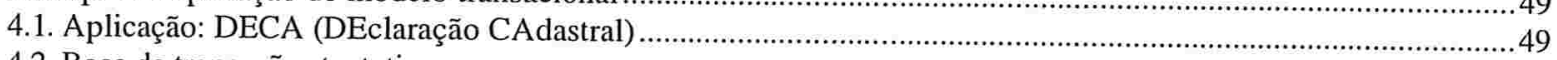

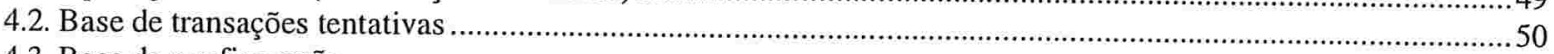

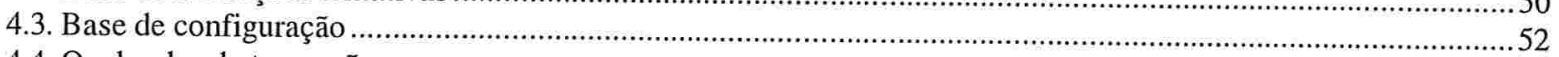

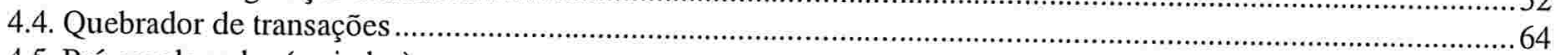

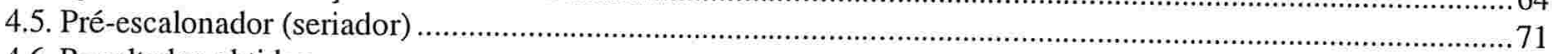

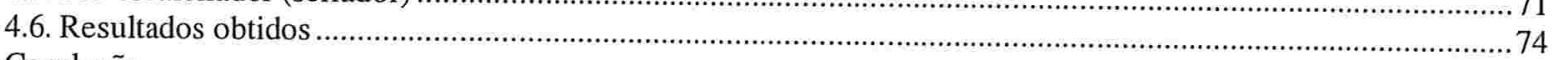

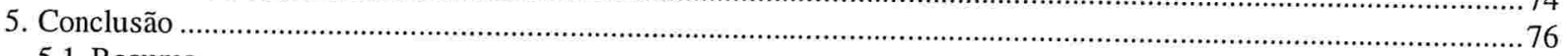

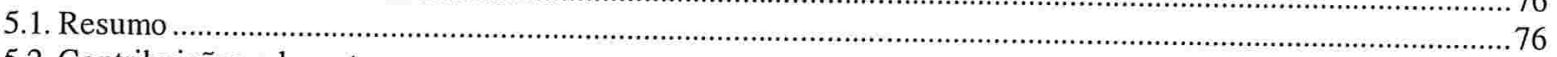

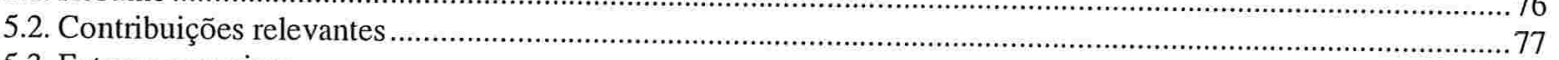

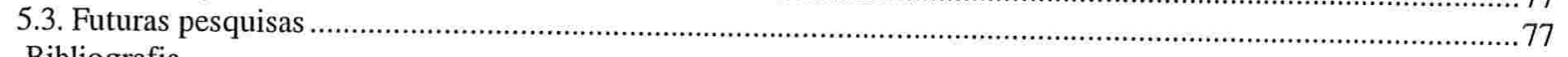

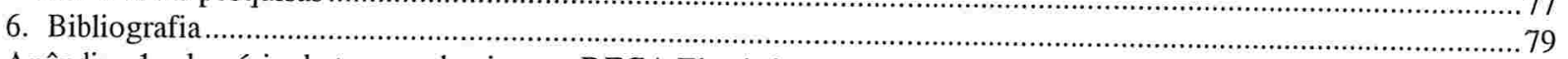

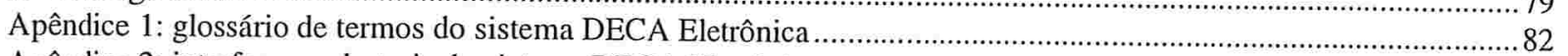

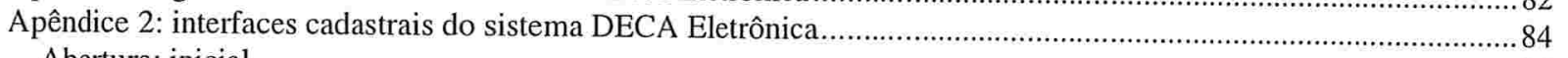

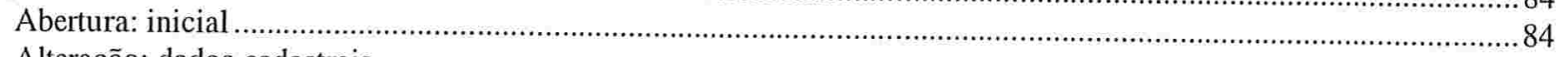

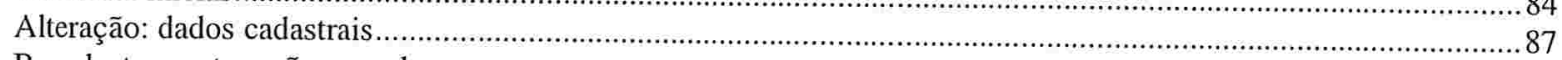

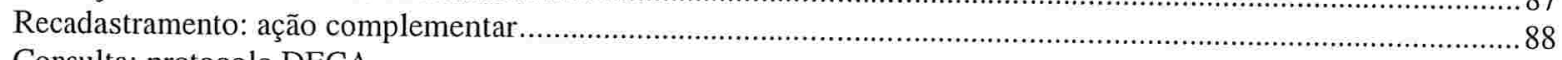

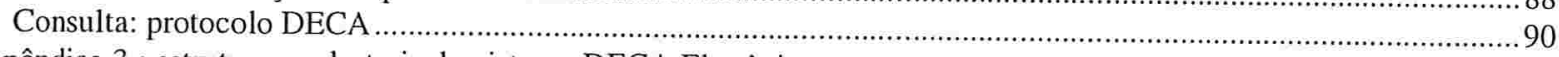

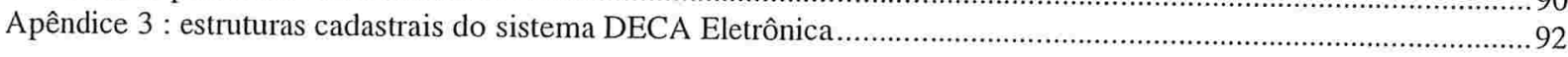




\section{Índice de Tabelas}

Tabela 1 - Estrutura da base de configuração para mapeamento dos conjuntos de dados particionáveis.

Tabela 2 - Estrutura da base de configuração para mapeamento das transações particionadas por conjunto de dados. 34

Tabela 3 - Estrutura da base de configuração para representação da origem e destino das transações. ........................38

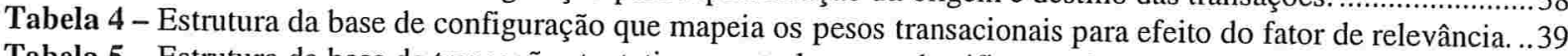

Tabela 5 - Estrutura da base de transações tentativas central com a classificação das transações segundo as prioridades.

Tabela 6 - Pseudo-algoritmo de quebra transacional do quebrador de transações................................................40

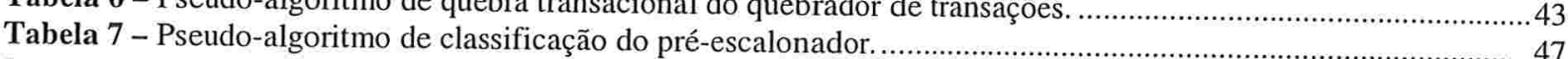

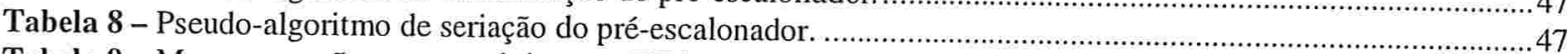

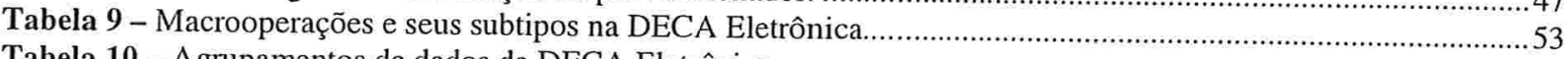

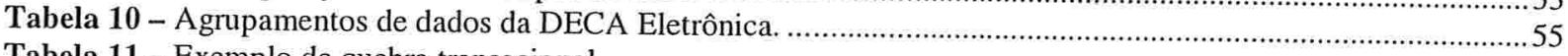

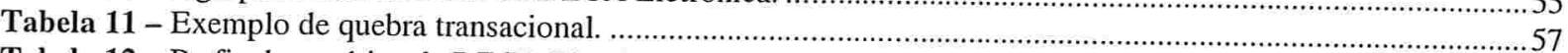

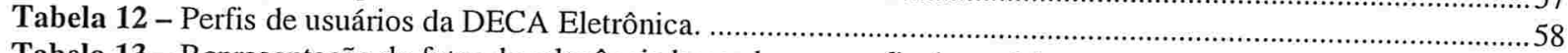

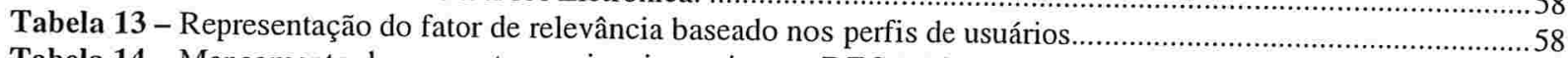

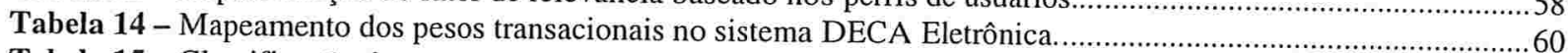

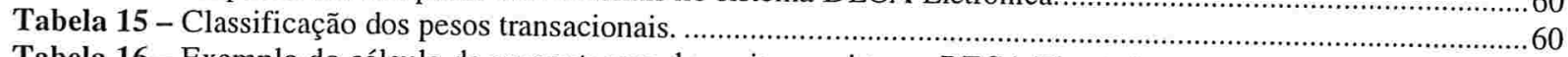

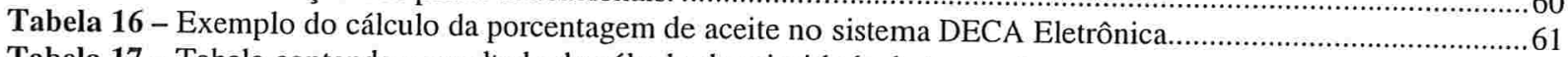

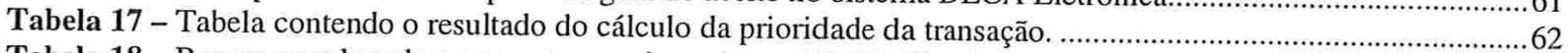

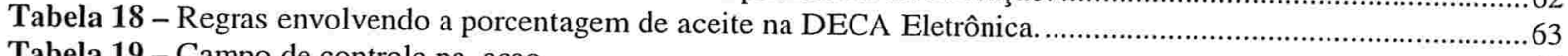

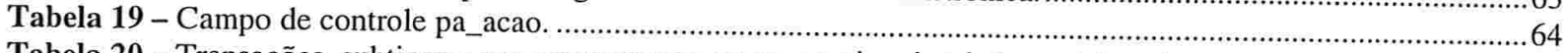

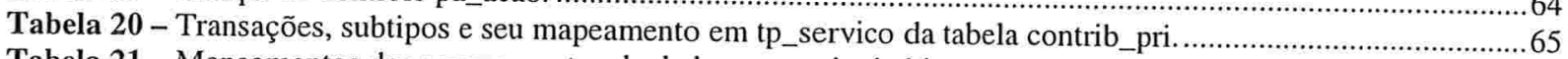

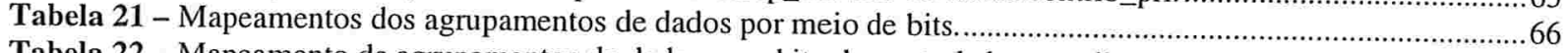

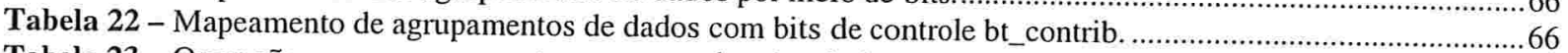

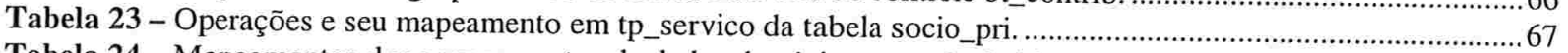

Tabela 24 - Mapeamentos dos agrupamentos de dados de sócio por meio de bits do bt_socio.............................................67

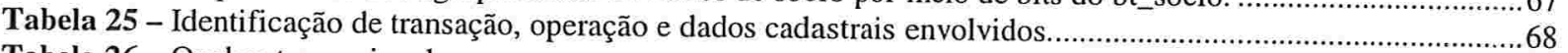

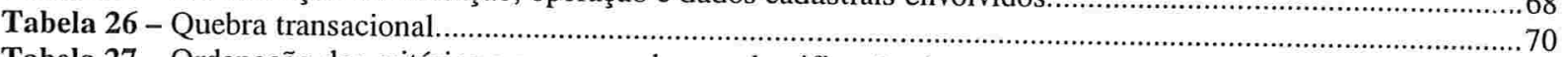

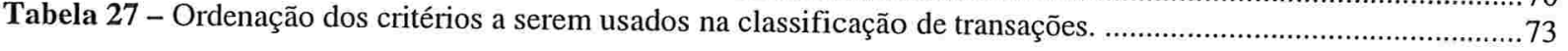

\section{Índice de Figuras}

Figura 1 - Transações partidas (parte 1).

Figura 2 - Transações partidas (parte 2).

Figura 4 - Bases de transacional segundo as aplicações cliente e servidora....................................26

Figura 5 - Base de dados de configuração localizadas no servidor central e nos nós clientes......................................22

Figura 6 - Quebrador de transações localizado no servidor centrator central.............................................................31

Figura 7 - Pré-escalonador localizado no servidor central

Figura 8 - Tela cadastral da DECA Eletrônica.

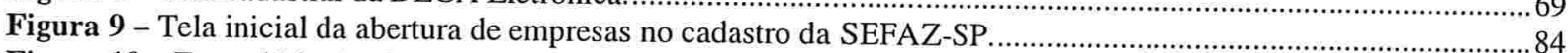

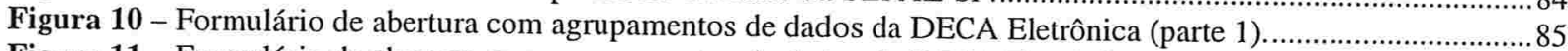

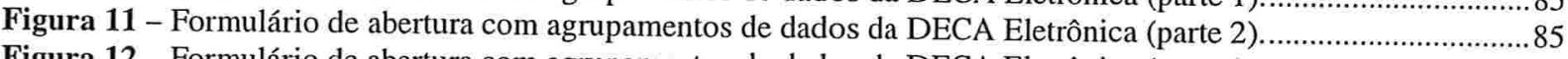

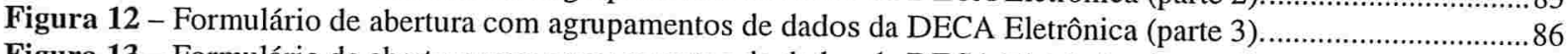

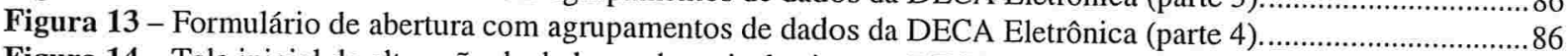

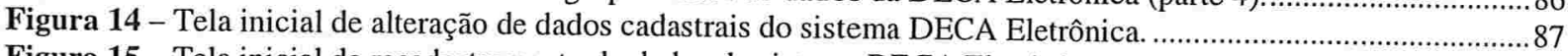

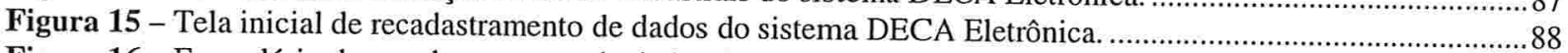

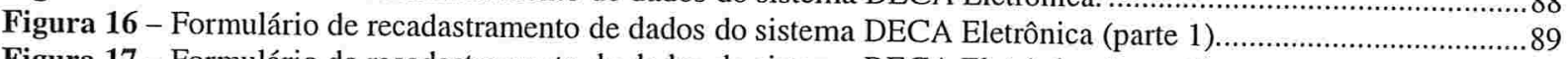

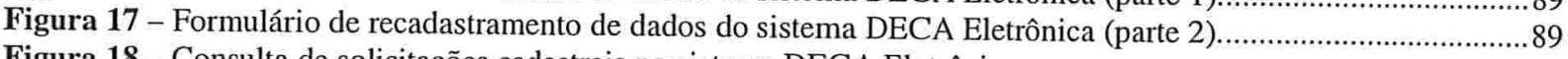

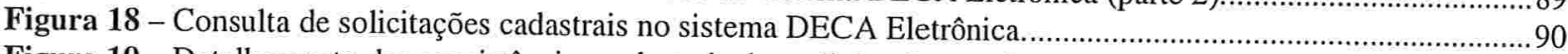

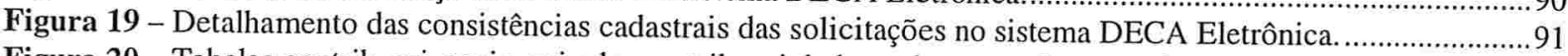

Figura 20 - Tabelas contrib_pri, socio_pri e logcontrib_pri da base de transações tentativas da DECA Eletrônica. ...99 


\section{Introdução}

\subsection{Descrição}

A crescente demanda do aumento da disponibilidade de recursos computacionais referentes ao acesso a bases de dados foi suprida pelo advento da computação móvel juntamente com o uso de bancos de dados autônomos [18]. Esses bancos permitem o acesso aos dados, mesmo em condições de isolamento de comunicação com os demais bancos de dados, por meio de armazenamento de cópias de dados locais, obtidas previamente por processos de replicação de dados [17]. Em relação a essa cópia local são permitidas operações de leitura e escrita sobre os dados, sendo necessário o posterior repasse dessas operações às demais instâncias de banco de dados existentes.

Em sistemas distribuídos não móveis também existem justificativas para o uso de banco de dados autônomos. Um exemplo é o incremento da segurança quanto a possíveis falhas de comunicação entre as instâncias dos bancos de dados existentes. Assim, na ocorrência de falhas de comunicação, o acesso ao banco de dados torna-se local para registro das operações pendentes visando à posterior propagação dessas transações após o restabelecimento da comunicação.

A grande dificuldade para viabilizar o uso de bancos de dados autônomos está relacionada à integração de transações postergadas que tornam-se conflitantes por causa das transações assíncronas. Tais transações são realizadas sobre cópias de um mesmo dado, localizadas em instâncias desconectadas de bases de dados. Dependendo da estratégia de sincronização adotada [17], problemas como bloqueio [17] e falta de sincronismo [17] podem ser encontrados no processo de integração, resultando na recusa da propagação das operações e no processo de desfazer transações nas instâncias de base de dados que as originaram.

Considerando as restrições de integração de transações postergadas supramencionadas, nossa proposta pretende viabilizar a existência de instâncias de bases de dados, que permitam a integração de transações conflitantes realizadas sobre réplicas de dados. Portanto este trabalho tem como hipótese de solução a parametrização de transações, conforme o conjunto de regras de domínio de aplicação, de modo a reduzir o conflito para a seriação.

Assim o banco de dados autônomo gerado utiliza critérios baseados nas regras do domínio de aplicação como parâmetros configuráveis. Esses parâmetros configuráveis são a base para estabelecer o critério de escalonamento que difere das aplicações convencionais que utilizam a teoria da seriação através do conceito de ordem parcial [17].

Esse estudo encontra-se organizado da seguinte forma: na seção 1 temos a delimitação e caracterização dos problemas e as hipóteses da solução proposta. A seção 2 referencia o levantamento bibliográfico dos demais estudos e a descrição do estado da arte das soluções existentes. Na seção 3 temos o desenvolvimento da solução proposta e na seção 4 um exemplo de aplicação da solução. A seção 5 apresenta a conclusão do trabalho e a seção 6 a bibliografia. Ao final da dissertação encontram-se os apêndices. 


\subsection{Delimitação e caracterização do problema}

Nesta seção realizaremos a delimitação e caracterização do problema envolvido na integração assíncrona de instâncias de bases de dados que, localizadas nos nós clientes ${ }^{1}$, armazenam informações obtidas segundo critérios de separação de dados [15]. Tais critérios são geralmente baseados em predicados [15] para identificação dos dados a serem replicados. Para esses dados replicados são definidas permissões de escrita e leitura com transações de escopo local. Posteriormente tais transações são repassadas às demais cópias para a devida integração.

Entendemos que a replicação e alocação autônoma das cópias de dados constituem um sistema de multibases de dados. Cada transação ocorrida em um determinado nó cliente precisa, em algum momento, ser repassada para as demais cópias do sistema por meio de um nó coordenador central.

Após serem efetuadas em um determinado nó autônomo, as transações devem ser repassadas às demais réplicas. Apenas os nós clientes que armazenam réplicas dos dados envolvidos nas transações devem ser atualizados. Tal processo é necessário, pois sua ausência pode comprometer a confiabilidade dos dados replicados nas instâncias de bases de dados localizadas nos nós clientes.

A seguir, considerando a característica principal de autonomia transacional das bases de dados, caracterizaremos os principais problemas e requisitos envolvidos nas várias etapas do processo de replicação / integração de dados.

\subsubsection{Conexão intermitente $[19,22]$}

Devido às restrições existentes em computadores móveis relacionadas aos recursos da máquina e às limitações de comunicação ocasionadas pelo baixo volume do canal de comunicação e sua intermitência, os bancos de dados autônomos surgem como uma opção para proporcionar maior disponibilidade de acesso aos dados das aplicações. Os exemplos de restrições são caracterizados por:

- Limitação de recursos: São várias as restrições existentes em computadores móveis [19, 22] relacionadas à disponibilidade de recursos. São exemplos de limitações a baixa autonomia das baterias para suprimento de energia, a quantidade restrita de memória secundária para armazenamento de dados e o processamento de máquina limitado à capacidade do processador utilizado. Todas essas limitações restrigem a capacidade de uso de tais computadores, bem como sua interação com o sistema.

- Baixo volume do canal de comunicação: O canal de comunicação [19, 22] que existe entre computadores móveis e os demais computadores participantes do sistema é, em geral, restrito devido, principalmente, à

\footnotetext{
${ }^{1}$ Nós clientes são as instâncias de bases de dados distribuídas que realizam transações assíncronas sobre réplicas de dados. A denominação cliente utilizada no texto não está relacionada ao modelo cliente-servidor, e sim ao modelo computacional distribuído.
} 
forma de conexão utilizada. Por exemplo, a comunicação sem fio [19, 22] sofre restrições no canal de comunicação, originadas essencialmente pela grande mobilidade dos computadores móveis e pelo seu posicionamento em locais distantes dos pontos de recepção do sinal de comunicação. Como resultado tem-se grande interferência no sinal e queda na qualidade do canal de comunicação. Já a utilização de linha discada também pode apresentar limitações quanto ao volume de comunicação, pois depende de diversos fatores, tais como: velocidade do computador (placa de comunicação), qualidade da linha telefônica (centrais de telecomunicações digital ou analógica), velocidade de acesso permitida pelos provedores de informações, canal de comunicação entre cidades e regiões e quantidade de usuários existentes em um determinado horário.

- Comunicação intermitente [19, 22]: Dependendo da comunicação utilizada entre os computadores, a troca de informações pode ser comprometida em maior ou menor grau, principalmente por causa da interrupção do canal de comunicação. O uso de comunicação sem fio apresenta alguns agravantes que podem tornar o canal de comunicação intermitente. O deslocamento dos computadores móveis e a redução da qualidade do sinal de comunicação ocasionada pelo distanciamento dos pontos de recepção de sinal podem resultar na interrupção ou queda do sinal de comunicação. A utilização de linha discada também pode sofrer interrupção na comunicação devido à queda de conexão ocasionada pelos mais diversos fatores, tais como limitação da linha telefônica ou grande número de usuários utilizando um determinado provedor de acesso.

\subsubsection{Replicação de dados}

É necessária uma maior atenção durante o processo de replicação de dados para a correta identificação dos dados a serem replicados em instâncias de bases de dados localizadas em computadores móveis. Tal atenção é decorrente das limitações de armazenamento existentes nos computadores móveis e de uma crescente necessidade na disponibilidade de uso dos sistemas computacionais. A replicação de dados não deve desconsiderar os limites computacionais existentes (espaço em disco ou rede de comunicação), mas atender às necessidades dos usuários que os acessarão localmente, mesmo quando permanecerem desconectados do restante do sistema.

Deseja-se que as diferenças existentes nas estruturas das bases de dados sejam transparentes aos usuários. Estes apenas se restringirão a saber que seus dados estão disponíveis localmente, e que posteriormente serão reintegrados ao restante do sistema. Os problemas relacionados à replicação de dados resumem-se em dois pontos:

- Critérios de separação de dados: São informações necessárias à identificação dos dados mais relevantes aos clientes durante o processo de replicação de dados. O conceito de predicado de separação [15] auxilia na identificação dos critérios utilizados na seleção dos dados a serem replicados. A maior preocupação é garantir que os dados replicados localmente atendam às necessidades de uso dos clientes. Pretende-se 
com isso evitar acessos aos dados remotos para busca de informações que não façam parte da base de dados local do nó.

- Estrutura da base de dados: As instâncias nó cliente de base de dados refletem as particularidades das aplicações cliente. O reflexo dessas particularidades nas bases de dados acontece por meio da estrutura ou esquema da base de dados. O processo de replicação deve respeitar tal estrutura, pois um mesmo conjunto de dados pode estar replicado em mais de um nó cliente, utilizando estruturas diferentes de bases de dados. Essa diferenciação pode acarretar dificuldades adicionais na integração de dados entre as várias instâncias de bases de dados. Possivelmente tais dificuldades serão resolvidas por meio de processos de integração de esquema [15]. A estrutura da base de dados deve atender à necessidade de dados locais do nó cliente e a aplicação que este utiliza.

\subsubsection{Transações conflitantes [17]}

A ocorrência de transações conflitantes entre as várias instâncias de bases de dados e a característica de desconexão por parte dos nós clientes limitam o processo de integração de transações ao uso de meios assíncronos para resolução de conflitos. Relacionado a esse modelo de integração assíncrona existem várias propostas para realização da sincronização de transações conflitantes [1, 2] utilizando vários tipos de algoritmos. Esses algoritmos visam auxiliar o processo de integração de forma a minimizar o número de conflitos existentes e diminuir ao máximo a quantidade de transações negadas pelo sistema.

O processo de sincronização utiliza diferentes formas de seriação de transações que beneficiam-se dos diferentes tipos de transação existentes [15], tais como comutativas e compensatórias. O uso de informações relacionadas aos limites de inconsistência entre dados [21, 26, 27, 28, 29] auxilia na decisão do processo de sincronização de transações. A seguir apresentamos alguns pontos que contribuem para a ocorrência de transações conflitantes.

- Atualização de dados locais: Atualizações de dados locais são permitidas aos nós clientes que acessam as instâncias de bases de dados localizadas nos computadores móveis. Essa premissa é desejada por causa da necessidade de maior disponibilidade de uso do sistema, mesmo em momentos de desconexão por parte do nó cliente.

- Latência de reconexão: Latência de reconexão está relacionado com a periodicidade que os nós clientes se reconectam ao sistema. Não é essencial aos clientes interagirem com as aplicações estando estas sempre conectadas ao sistema. Tem-se maior interesse que a mobilidade dos clientes e o acesso à aplicação estejam em primeiro plano. A comunicação do nó cliente com o sistema é necessária mas não primordial no momento inicial. Assim, é comum os nós clientes permanecerem a maior parte do tempo desconectados e somente repassarem suas transações ao sistema em momentos esparsos de conexão. 
- Semelhança entre os conjuntos de dados replicados: Diferentes clientes podem ter necessidade de acesso a um mesmo conjunto de dados. Tal coincidência é explicada por semelhanças existentes nos critérios de separação de dados utilizados no processo de replicação de dados. A replicação de dados comuns em mais de uma instância de base de dados cliente com permissão para atualizações locais, somado à latência de reconexão, ocasionam o aparecimento de transações conflitantes.

- Transações tentativas: É necessária a reconexão da aplicação cliente com o restante do sistema para a transmissão das transações realizadas sobre as réplicas locais às demais instâncias de bases de dados existentes. Até o recebimento dessas transações pelo sistema e a confirmação da integração, as transações locais são consideradas transações tentativas, e poderão ser desfeitas ou refeitas caso outras transações originadas por outros clientes tenham sido aceitas antes, modificando ou indisponibilizando os dados-alvo dessas transações locais. É preciso que os clientes tenham conhecimento da durabilidade [17] relacionada às transações tentativas, para que as aplicações e seus usuários não sejam prejudicados.

- Controle de validade das transações: As operações realizadas pelos nós clientes em suas bases de dados locais geram transações de longa duração [17] que são inicializadas pelos clientes, depois permanecem localmente registradas em suas instâncias de bases de dados até serem transmitidas ao sistema para validação / aceitação. Posteriormente são validadas obtendo sucesso ou falha no processo de aceitação, resultando na comunicação do retorno de tal processo ao nó cliente, para que então as transações sejam finalizadas. A obtenção de sucesso no processo de aceitação pode inviabilizar possíveis transações tentativas existentes nas demais instâncias de bases de dados que operam sobre o mesmo conjunto de dados, mas que ainda não foram validadas pelo sistema. A validação dessas transações conflitantes pode resultar na negação de outras transações pelo sistema, devendo estas serem desfeitas ou refeitas pelos nós clientes. A duração das transações está relacionada ao tempo de latência de reconexão do nó cliente, à semelhança entre os conjuntos de dados replicados e ao processo de validação das transações no sistema. Quanto maior o tempo de duração de uma transação, maiores as chances de ocorrerem conflitos entre as transações.

- Propagação das transações aceitas: Após serem aceitos pelo sistema, os dados atualizados pelas transações validadas devem, posteriormente, ser retransmitidos às várias instâncias de bases de dados que contêm réplicas dos dados envolvidos. A troca de informações para sincronizar as bases de dados cliente e servidor é realizada por meio do canal de comunicações existente. 


\subsection{Hipóteses e objetivos da solução}

Uma vez delimitado e caracterizado o problema relacionado à integração assíncrona de instâncias de bases de dados, prosseguiremos com a descrição da hipótese da solução proposta.

O modelo tradicional de integração de transações baseia-se na teoria da seriação através da ordem parcial (bloqueio e pré-ordenação) para sincronizar transações conflitantes. Essa seriação não atende às necessidades das bases de dados que operam de forma desconectada, através de bancos de dados autônomos, por causa das possíveis inconsistências entre os bancos de dados, que podem ser provocadas por problemas de sincronismo [17] entre as bases clientes e servidora. Desejamos que a solução proposta utilize o modelo desconectado junto às várias instâncias de bases de dados autônomas.

Conforme a necessidade, propomos um outro tipo de ordem fundamentado em controle transacional para seriar as transações conflitantes. O controle transacional utiliza informações do domínio de aplicação para caracterizar as transações, gerando parâmetros para a quebra e pendência transacional.

Quebra transacional corresponde ao processo de divisão das transações em subtransações menores, segundo os parâmetros do controle transacional. Tal divisão busca quebrar uma transação nas menores frações de transação possíveis.

Pendência transacional está relacionada à porcentagem de aceite de uma transação. O conceito de porcentagem de aceite ${ }^{2}$ representa o índice de aceitação de uma transação e serve como métrica para o controle das restrições de aceitação. Por causa da quebra transacional, a aceitação de subtransações contribui para o aumento da porcentagem de aceite da transação original. Assim, a pendência transacional está relacionada ao índice de aceitação da transação.

Mais detalhes a respeito desses conceitos podem ser encontrados na seção 3 referente à solução proposta, no item modelo transacional conceitual.

Temos a seguir a descrição de objetivos a serem atingidos com a solução para integração de transações conflitantes, contudo, neste trabalho, nos restringiremos aos objetivos 1 e 2 .

1. Avaliar e estruturar os parâmetros do modelo transacional que são extraídos das aplicações e baseados nas regras do domínio de aplicação existentes e predefinidas.

2. Definir o pré-escalonador, localizado no servidor central, que se fundamenta nos parâmetros do modelo transacional para realizar o préescalonamento das transações clientes considerando as regras do domínio

\footnotetext{
${ }^{2} \mathrm{O}$ conceito porcentagem de aceite será descrito oportunamente e denota uma métrica proposta para o cálculo da aceitação das transações clientes conforme o aceite das subtransações geradas pelo processo de quebra transacional.
} 
de aplicação. Posteriormente escalona as transações por meio de um SGBD relacional.

3. Viabilizar a utilização de banco de dados autônomo, que realizam transações (leitura e escrita) de forma independente das demais bases de dados, por meio de acesso às cópias de dados locais, para posterior repasse dessas operações às demais instâncias de bases de dados.

4. Permitir que, após a ocorrência de falhas de comunicação entre as bases de dados, seja feita a propagação das operações realizadas nos períodos de não-comunicação, sem comprometer a disponibilidade de acesso aos dados.

5. Identificar as características e os critérios referentes ao processo de replicação de dados, que possam auxiliar no processo de integração de transações conflitantes.

6. Definir a estrutura das bases de dados localizadas nas instâncias clientes e no servidor central, para recepção e armazenamento dos dados e das operações realizadas sobre os mesmos. 


\section{Levantamento bibliográfico}

Muitas pesquisas [30, 31, 32, 33, 34, 35] têm sido direcionadas para esquemas de replicação otimistas em banco de dados móveis com reconciliação assíncrona. O problema está sendo muito estudado no contexto de sistemas de arquivo. Gray [4] apresenta um sistema e um modelo de replicação para bancos de dados móveis. Bayou $[2,3]$ propõe um outro modelo para repositório móvel de dados. Neste modelo as informações necessárias para o processo de reconciliação estão incluídas em cada atualização do repositório de dados. Dataman $[5,6,7,8$, 9] apresenta uma proposta baseada na fragmentação de objetos, não exigindo da aplicação qualquer semântica para realizar a fragmentação dos dados. Calton $[21,26,27,28,29]$ introduz o conceito de Epsilon-Transaction que permite o tratamento de inconsistência nas transações tal que o erro possa ser reduzido a uma margem aceitável.

O novo modelo proposto diferencia-se dos demais no que se refere à flexibilidade do uso de critérios semânticos, baseados nas regras de negócio predefinidas pelas aplicações, para integração assíncrona de transações conflitantes. Mais detalhes são descritos na seção 3. Nos itens a seguir faremos uma síntese das soluções existentes.

\subsection{Bayou}

\subsubsection{Descrição}

Em Bayou [2, 3] as réplicas são cópias locais completas do repositório de dados. Cada servidor deve manter uma cópia. Essas cópias podem ser acessadas por outras máquinas conectadas a tais servidores. Todos os servidores estão fracamente conectados. Cada transação feita desde a última vez que o banco de dados esteve globalmente consistente é registrada em um arquivo de $\log ^{3}$. Sempre que dois servidores Bayou conectam-se, todas as transações no log são refeitas e os logs são combinados na ordem da marca de tempo. Logs combinados são usados para repetir as transações em ambos os servidores e tornar as bases de dados mutuamente consistentes. Bayou garante que, na ausência de qualquer nova transação, a base de dados apresentará um estado consistente em todos os servidores, contanto que os servidores não fiquem desconectados para sempre.

\subsubsection{Estratégias de replicação com consistência fraca}

As estratégias de replicação de dados em Bayou variam segundo o grau de rigor exigido na consistência. Tal escolha afeta diretamente a latência das operações realizadas, a eficiência do canal de comunicação e a própria consistência dos dados. Assim, quanto maior for a consistência exigida, menor o tempo de latência das operações e o uso do canal de comunicação.

Uma opção de estratégia de replicação seria manter as réplicas totalmente independentes, onde as alterações nos dados são permitidas sem a obrigatoriedade de

\footnotetext{
${ }^{3}$ Utilizaremos o termo log para denotar o arquivo com o registro de operações realizadas sobre dados armazenados em uma base de dados.
} 
que tais mudanças sejam comunicadas a outros servidores. Essa situação é muito útil em sistemas que não necessitam compartilhar as alterações das réplicas, como por exemplo, as informações imutáveis de um código de aplicativo.

Outra opção é a estratégia de consistência forte na qual toda alteração deve ser propagada imediatamente para todo o sistema, impossibilitando que as demais réplicas dos dados sejam utilizadas por outras operações, até que todo o processo de propagação esteja concluído. Esse modelo apresenta o maior grau de consistência possível, já que garante que todas as réplicas estarão consistentes. Em geral, a latência das operações é muito alta, pois cada modificação acarreta a atualização de todos os servidores. Tal situação é desejada em sistemas nos quais as aplicações exijam um alto grau de consistência dos dados.

Uma terceira opção é a utilização do protocolo Anti-Entropia [2, 3] para a propagação das transações. Nessa estratégia, cada servidor utiliza um log que representa as alterações feitas nos dados. Quando uma transação é realizada, um registro é feito no log contendo uma marca (marca de tempo ou número seqüencial) gerada pelo servidor, juntamente com o identificador da máquina servidora. O propósito dessa marca é definir uma ordem parcial em todo o sistema. A propagação das transações consiste em fazer com que o log dos servidores contenha o mesmo conjunto de marcas de atualizações. A propagação se dá entre pares de servidores, sempre de forma unidirecional, ou seja, há integração entre os logs dos servidores.

\subsection{Esquema de replicação em Duas Camadas}

\subsubsection{Descrição}

Gray [4] propõe um esquema de replicação mestre / escravo [16] modificado. No esquema de replicação mestre, cada objeto possui um nó mestre que armazena a cópia primária do objeto. Somente a cópia primária sofre atualização e é propagada para as demais réplicas do objeto. Todas as réplicas estão disponíveis apenas para operações de leitura. No esquema modificado de Gray, cada objeto também possui um nó mestre, mas as atualizações são permitidas tanto neste como nas demais réplicas do objeto. A diferença é que atualizações realizadas nas réplicas são consideradas transações tentativas, e as realizadas no nó mestre, transações bases.

\section{Existem dois tipos de nós:}

Nó móvel: Permanece a maior parte do tempo desconectado; possui uma réplica do banco de dados; pode ser nó mestre de algum objeto; realiza transações tentativas sobre réplicas dos objetos nas quais não é nó mestre. Nesta situação, armazena versões dos objetos replicados: versão mestre que armazena o valor recebido mais recente do objeto mestre, e versão tentativa, alvo das transações tentativas.

Nó base: Sempre conectado; possui réplica do banco de dados; contém a maioria dos objetos como nó mestre.

Nós móveis realizam transações tentativas, atualizando a versão tentativa do 
objeto replicado. Quando se reconectam aos nós bases tentam atualizar os nós mestres, através da execução de transações bases geradas a partir de suas transações tentativas. Também na reconexão, o nó móvel quando nó mestre de algum objeto, propaga as modificações às demais réplicas do objeto através do envio das transações. Além disso, recebem transações vindas dos nós bases, que sobrepõem a versão mestre dos objetos replicados.

Os nós bases recebem e enviam transações de réplicas aos nós móveis para, respectivamente, atualizarem suas réplicas locais quando o nó móvel for o nó mestre do objeto e propagarem transações realizadas sobre seus objetos mestre. Recebem também transações tentativas dos nós móveis, que serão executadas como transações bases. A validação da execução dessas transações é realizada segundo critérios de aceitação, definidos pela aplicação, que verificam se o resultado da transação base não fere os critérios preestabelecidos, como por exemplo, o saldo positivo de uma conta corrente após a realização de algumas operações bancárias.

Caso a transação tentativa falhe, o nó que originou a transação será informado da falha e do motivo. Tal esquema garante que a base mestre sempre estará consistente, pois somente ela aceita atualizações de objetos. Além disso, as réplicas precisam somente contactar o nó mestre para saber se sua transação tentativa foi executada, diferentemente de outras abordagens que utilizam o conceito de grupo onde a transação só terá validade após ser propagada a todas as réplicas do objeto, localizadas em diversos nós.

Se a transação base pôde ser completada com sucesso, o nó mestre envia atualizações aos nós réplicas para que as modificações sejam propagadas. Quando a transação base estiver concluída, então a transação poderá ser considerada confirmada e o banco de dados caminhará para um estado consistente.

\subsubsection{Esquemas de replicação}

Quando se executam transações bases, o esquema de replicação em duas camadas se comporta como o esquema Lazy Master [12], pois neste são permitidas apenas transações de atualização sobre o objeto mestre.

Se a transação base não pôde ser completada com sucesso, então ela será reprocessada até que se obtenha sucesso. No esquema de replicação em duas camadas não existe o processo de reconciliação, muito utilizado em esquemas de replicação Lazy [12, 31, 33, 35] para resolução de conflitos. Relacionando os dois esquemas, poderíamos obter uma correspondência entre a taxa de falha na reconciliação dos esquemas Lazy e a taxa de falha causada pelo critério de aceitação, no que se refere à quantidade de atualizações não-sucedidas.

O processamento de transações bases pode produzir resultados diferentes daqueles obtidos pelas transações tentativas, o que é aceitável para algumas aplicações. Mas existem casos onde tais mudanças podem não ser aceitáveis, como por exemplo, se o preço de um item foi aumentado ou a quantidade de estoque modificada através de transações bases originadas em outros nós móveis, então o preço de venda ou a quota de entrega devem ser revistos com os nós envolvidos. 
O usuário do sistema deve saber que as transações realizadas serão consideradas transações tentativas, até que se tornem transações bases.

A motivação desse esquema duas camadas é permitir atualizações em computadores móveis quando desconectados, diferentemente dos esquemas de replicação mestre (Lazy) que inibem operações desconectadas. Outra motivação é combinar os benefícios do esquema de replicação mestre modificado que permite atualizações locais de réplicas e atualizações seriadas na cópia primária, obtendo assim um banco de dados resultado de execuções seriadas.

\subsection{Dataman}

Trata-se de um modelo proposto pelo Laboratório de Computação Móvel Dataman, do Departamento de Ciências da Computação, da Universidade de Rutgers, Nova Jersey, Estados Unidos.

\subsubsection{Modelo básico do banco de dados}

O modelo consiste de um banco de dados centralizado com dois tipos de clientes: os tradicionais e os móveis. Clientes móveis são capazes fazer o download dos dados, operar sobre eles (mesmo quando não há conexão com o servidor) e propagar atualizações de volta para o banco de dados centralizado. Clientes tradicionais não podem operar de forma desconectada.

Os dados móveis, replicados nos clientes móveis, são fragmentos horizontais das relações. O cliente pode desconectar-se do servidor, e as aplicações podem continuar consultando e atualizando fragmentos no nó cliente. Quando conectados, clientes móveis comportam-se como clientes tradicionais e têm total acesso ao banco de dados.

Com a introdução de clientes móveis, servidores de banco de dados podem esperar duas cargas distintas de trabalho. Uma gerada pelas requisições dos clientes móveis e outra resultante das consultas convencionais dos clientes tradicionais. A carga apresentada pelos clientes móveis no banco de dados centralizado é sazionada devido ao seu modo de operação (download do dado seguido por períodos de pouca ou ausência de atividade e por excessivas operações de validação das atualizações de dados e escritas de $\log$ ).

O servidor é o ponto de sincronização desse modelo. Todas as transações devem ser propagadas ao servidor. Este também controla o privilégio de acesso para vários usuários. Relações inteiras são armazenadas no servidor (ao contrário dos clientes móveis que podem armazenar parte das relações). A organização física das relações no servidor está em termos dos fragmentos físicos, de forma a auxiliar uma rápida reintegração e replicação dos dados. As transações dos clientes tradicionais somente são executadas no servidor.

\subsubsection{Organização dos dados no servidor}

É desejado que o acesso a dados pelos clientes móveis siga o princípio de 
localidade, isto é, que os dados acessados estejam relacionados à localização do cliente móvel. Para permitir isso, as relações do servidor são fragmentadas horizontalmente, de forma a otimizar a eficiência da replicação e da reintegração. O cliente não precisa especificar explicitamente de quais fragmentos fará o download.

Os fragmentos físicos são unidades de particionamento, reintegração, controle de concorrência e controle de acesso do modelo. Devem ser cuidadosamente escolhidos para garantir a localidade de acesso dos típicos clientes móveis. Cada cliente móvel deve informar ao servidor os fragmentos que ele pretende utilizar e não precisa replicar o fragmento inteiro. No entanto, do ponto de vista do servidor, o cliente pode replicar todos os fragmentos. É de responsabilidade do servidor prover meios de resolução de conflitos. O servidor deve também controlar o acesso a cada fragmento e manter um mapeamento entre clientes e os fragmentos que ele replicou.

\subsubsection{Controle de concorrência e modelo de consistência}

Como aos clientes móveis é permitida a atualização local dos dados, temos então um modelo de consistência fraca. Contudo, diferentes clientes podem tentar atualizar o mesmo dado de diferentes formas. Assim o estado global do banco de dados torna-se inconsistente e o servidor tem que tratar as transações conflitantes.

Existem dois esquemas para tratar os problemas de consistência na presença de desconexão eminente. O primeiro esquema é o pessimista, e requer explícita sincronização antes da desconexão para manter a consistência. Um exemplo é o modelo check in / check out em que o servidor simplesmente bloqueia todas as requisições de atualização provindas dos demais clientes eliminando assim conflitos com o custo de reduzir a disponibilidade do sistema. O segundo esquema é o otimista, e permite que transações conflitantes de todos os clientes móveis sejam resolvidas na reconexão. Esse esquema é difícil de implementar por causa dos conflitos na reconexão. No entanto, é o mais atrativo já que provê alta disponibilidade do sistema.

\subsection{Epsilon Serializability}

Epsilon Serializability (ESR) [21, 26, 27, 28, 29] é um ambiente de trabalho que oferece uma solução para bases de dados autônomas que desejam realizar integração assíncrona. A idéia geral do ESR é preservar a seriação mesmo com certo limite de inconsistência.

Quando uma inconsistência converte para zero, ESR serializa a transação. ESR permite um grau de inconsistência controlado tal que o erro possa ser reduzido a uma margem aceitável.

Esse controle é bem granulado de maneira que as transações podem controlar sua própria margem de erro. Essa característica é desejada pois bases de dados autônomas devem tolerar inconsistências temporárias durante a realização de transações autônomas e repará-las quando o sistema retorna ao modo corporativo.

O conceito de Epsilon-Transaction (ET) foi criado para permitir o tratamento de inconsistência nas transações. Em cada transação, E-especification denota os limites 
importados e exportados de inconsistência. Dependendo dos limites importados e exportados de inconsistência, as leituras e escritas são conflitantes ou não. Tais índices de inconsistência são repassados às transações que utilizam dados "sujos"

Quando operações de leitura e escrita são realizadas sobre dados "sujos" é necessário o tratamento de tais transações pois o banco de dados pode se tornar inconsistente. Para isso existe o processo de Restauração de Consistência Assíncrona $(R C A)$. Os métodos de restauração de inconsistência analisam o histórico de transações efetuadas em busca de violações de consistência que superem os limites predefinidos de inconsistência das transações compensatórias.

Caso a superação do limite de inconsistência seja observada, três ações podem ser tomadas: interromper a transação compensatória $E T$, desfazer transações aceitas $E T$ até alcançar um limite aceitável de inconsistência ou anotar o conflito e continuar. Essa última opção é utilizada para analisar o histórico final com todas as violações de inconsistência e identificar, dependendo do tamanho da inconsistência observada, qual a melhor ação a ser tomada.

Diversas situações reais foram testadas com o modelo proposto, tais como sistema de reservas de passagens e aplicação bancária. Uma característica marcante dessa proposta é que em ESR a noção de correção independe da semântica da aplicação.

\subsection{Síntese dos trabalhos citados}

Em Bayou [2, 3], as réplicas são armazenadas em repositórios de dados, e não necessariamente em banco de dados. A propagação das transações ocorre por meio da reconciliação do log com os repositórios de dados se comunicando por conexões peer to peer [16]. Além disso, não existe ordem total na execução das transações. A consistência global dos dados não é totalmente garantida. Dependendo do grau de complexidade da reconciliação dos logs de cada aplicação, eventuais conflitos que não são solucionados devem ser tratados pela aplicação, pois o sistema não dispõe de tal recurso. Isso em alguns casos poderá exigir que operações contidas em um determinado log sejam desfeitas.

No esquema de replicação em duas camadas proposto por Gray [4], a arquitetura de banco de dados é baseada no modelo mestre / escravo de controle de consistência [16]. Nele, todas as transações somente são validadas se forem atualizadas no nó mestre, segundo critérios de aceitação estabelecidos pelo sistema. Esta é uma forma de consistência bastante utilizada comercialmente e que se assemelha em parte ao modelo centralizado de controle de consistência da solução proposta na seção 3 .

Em Dataman é proposto um modelo de banco de dados relacional mais maduro e não requer que o cliente mantenha uma cópia de toda a relação ou banco de dados, ao contrário do que ocorre em Bayou. Além disso, a resolução de conflitos é transparente para a aplicação. O sistema pode ser especialmente projetado para prover

\footnotetext{
${ }^{4}$ Originalmente denominada dirty pelo autor.
} 
automaticamente a resolução de conflitos.

Calton utilizou o conceito Epsilon Serializability para o cálculo da métrica de inconsistência no processo de integração de transações assíncronas. Para isso o processo de seriação adotou algoritmos de sincronização modificados para tratamento de importação e exportação de inconsistências entre transações conflitantes. 


\subsection{Estado da arte de implementação}

Cloudscape [10] e JDataStore [11] são bancos de dados móveis existentes no mercado que permitem a realização de transações assíncronas para posterior propagação às demais instâncias de bancos de dados. Realizam a representação da partição do banco de dados, implementam sincronização central das transações assíncronas, utilizam o conceito de transação provisória e durável, e possibilitam a configuração de regras e critérios para manipular sincronizações conflitantes.

Java 2 Enterprise Edition (J2EE) [23] é um conjunto de serviços padronizados que reduz a complexidade e aumenta a produtividade de desenvolvimento de aplicações distribuídas/multicamadas.

\subsubsection{Cloudscape}

Cloudscape, desenvolvido pela IBM, é um sistema gerenciador de banco de dados relacional objeto (ORDBMS), escrito inteiramente em linguagem java, que permite ser encapsulado em qualquer aplicação java, não necessitando que esta se conecte a um banco de dados central, pois realiza chamadas locais ao ORDBMS. Para isso não necessita de quaisquer softwares adicionais para conexão em rede.

Sua utilização com outras aplicações java torna-se transparente ao usuário pois não requer administração e sua execução é na mesma máquina virtual. Permite também armazenar dados exatamente como a aplicação usa, isto é, objetos java, não necessitando de conversão dos modelos de negócio para outra forma de dado.

A razão para usar um sistema gerenciador de banco de dados, em vez de outra forma de armazenamento de informação, é permitir consultas mais complexas sobre um conjunto de dados, utilizar o processamento transacional, e ser um meio persistente de armazenagem de dados.

Cloudscape é dividido em três produtos: Cloudscape, que é o núcleo do produto; Cloudconnector, ambiente para construção de aplicações cliente/servidor, provendo conectividade JDBC (Java DataBase Connection) e HTML (HyperText Markup Language) para Cloudscape; Cloudsync, responsável pela sincronização de dados do sistema entre as várias aplicações de um sistema distribuído.

Cloudscape dispõe também de um ambiente, em seu núcleo, para a criação de aplicações cliente / servidor, chamado RmiJdbc. Esta é uma alternativa ao uso do Cloudconnector, que constitui um segundo produto sendo vendido separadamente. Já a sincronização de dados somente pode ser realizada com a aquisição do produto Cloudsync.

A sincronização em Cloudscape é um processo no qual copiam-se os dados originários de um banco de dados central para um ou mais banco de dados destino, localizados nos clientes móveis, e controla-se a consistência do dado. Como a sincronização em Cloudscape é baseada em mensagem, os bancos de dados remotos não precisam estar continuamente conectados por uma rede. Esses bancos precisam somente se conectar intermitentemente, para atualizarem seus dados locais no banco de 
dados central através de envio e recepção de mensagems HTTP. Tal sincronização é realizada de forma transparente, sem necessidade de interação do usuário.

Ao utilizar Cloudscape, devem-se seguir algumas orientações para que as atualizações nos dados sejam mantidas. Após o término do uso do banco de dados, deve-se finalizá-lo para que todas as alterações tenham a garantia de que foram escritas no $\log$ do banco de dados. Caso não se proceda da forma descrita, na primeira execução do sistema o processo de recuperação será executado, restaurando o último estado consistente do banco de dados, baseado nas informações armazenadas no log. Tal processo de restauração também é acionado após a interrupção da execução do sistema em virtude da ocorrência de alguma falha. O log do banco de dados não armazena apenas erros, mas também informações sobre a inicialização e finalização da execução do banco de dados.

Cloudscape dispõe de uma aplicação gráfica chamada Cloudview que facilita a manipulação do banco de dados, permitindo a criação de tabelas e chaves primárias e estrangeiras, a entrada de dados graficamente ou por comandos SQL, a abertura e execução de arquivos batch de SQL etc. Dispõe também de ferramentas administrativas, tais como Lock Diagnostics, Consistency Checker e Backup Utility, para facilitar o gerenciamento do banco de dados.

\subsubsection{JDataStore}

JDataStore, produzido pela Inprise, é um banco de dados relacional objeto, também inteiramente na linguagem java, que permite ser anexado a outras aplicações java, e apresenta as seguintes características: tamanho pequeno, alta eficiência, portabilidade, baixo custo de administração, replicação / sincronização com qualquer banco de dados que tenha suporte a drive JDBC, gerenciamento transacional e recuperação de falha. Um simples arquivo JDataStore pode conter múltiplas estruturas de dados chamadas streams. Um stream pode ser uma tabela, um índice secundário para uma tabela, um arquivo arbitrário ou mesmo um objeto java.

Existem diversas formas para acessar os dados armazenados em um banco de dados JDataStore. Uma escolha é usar os drives JDBC escritos em java, que têm suporte a SQL-92, ou utilizar algum componente padrão EJB (Enterprise Java Beans) para realizar conexões a banco de dados.

O drive JDBC fornecido permite acessos locais e remotos utilizando o padrão industrial SQL call-level interface. Proporciona consultas otimizadas capazes de acessar as tabelas armazenadas no arquivo JDataStore, e acesso multiusuário através da rede.

JDataStore aumenta a capacidade atual de armazenamento de dados nos clientes, pois é um banco de dados que pode manipular até 2 bilhões de registros por tabela. Permite também aos clientes móveis trabalhar com persistência, proporcionando computação desconectada com desfeita de transações e recuperação da falha.

Transações e recuperação da falha podem ser habilitadas no banco de dados JDataStore apenas configurando-se algumas propriedades como diretório do arquivo de 
log, tamanho máximo do arquivo de log, tamanho dos blocos do arquivo de log etc. Existe um valor default para todas essas propriedades, o que reforça ainda mais a característica de custo zero de administração da ferramenta. Em algumas situações críticas a aplicação decide qual decisão tomar. Por exemplo, após uma falha do sistema, na próxima vez que JDataStore for utilizado, o banco automaticamente iniciará a recuperação dos processos para refazer o trabalho das transações que estavam em progresso, e também refaz o trabalho das transações ainda não propagadas. O sistema ainda controla a limpeza automática de antigos arquivos de log, no qual as transações já foram todas propagadas com sucesso.

Componentes específicos tratam a replicação dos dados e a sincronização das transações. Logo que os dados são retornados do servidor origem, tornam-se automaticamente persistentes no banco de dados JDataStore. Agora a aplicação pode se desconectar e acessar os dados localmente. O dado pode ser lido e escrito usando-se drives JDBC JDataStore. Tabelas dentro do JDataStore automaticamente registram todas as operações de inserção, atualização e remoção. Então quando a aplicação necessitar, se reconecta ao servidor de origem dos dados, e componentes do JDataStore saberão quais operações devem ser propagadas. Esses componentes têm capacidade de sincronização e através de mecanismos de resolução de conflitos salvam as mudanças no servidor de origem, identificando os relacionamentos e ordenando operações para manter a integridade referencial do banco de dados.

\subsubsection{J2EE}

O padrão Java 2 Enterprise Edition (J2EE) [23] é uma proposta da Sun Microsystems. A plataforma J2EE fornece um conjunto de serviços padronizados que reduz a complexidade e aumenta a produtividade de desenvolvimento de aplicações distribuídas / multicamadas.

Novas tecnologias para servir de apoio à plataforma J2EE foram criadas, entre elas o Enterprise Java Beans (EJB) [24]. EJB representa um modelo de componentes/objetos distribuídos que permite a criação de componentes do lado servidor, simplificando a implementação das camadas intermediárias e fornecendo automaticamente controle transacional, escalabilidade, conexão com banco de dados, segurança e portabilidade. Esses serviços são fundamentais para a implementação das camadas intermediárias.

Outra tecnologia criada para dar apoio à plataforma J2EE é o serviço para o gerenciamento distribuído de transações. A plataforma J2EE fornece apoio às transações por meio de duas especificações [25]: Java Transaction API (JTA) e Java Transaction Service (JTS). JTA é uma biblioteca de alto nível, independente de implementação e protocolo que permite a Aplicações e Servidores de Aplicações acessar e gerenciar transações. JTS especifica a implementação de um gerenciador de transações que disponibiliza JTA e implementa o mapeamento Java para Serviço Transacional de Objetos (Object Transaction Service - OTS) utilizando o protocolo IIOP (Internet Inter-ORB Protocol). 
Um conceito muito importante para o entendimento da arquitetura de aplicações J2EE é o de Container. Os Containers representam um ambiente operacional que fornece recursos e infra-estrutura necessária à publicação e execução de componentes, assim encapsulam a complexidade do ambiente corporativo e fornecem independência de plataforma aos componentes.

\section{Gerenciamento de transações em EJB}

Uma arquitetura como J2EE com apoio à transação simplifica o desenvolvimento da aplicação porque livra o desenvolvedor da complexidade da recuperação de falhas e da programação para multiusuários.

O EJB Container disponibiliza transações "normais" (transações aninhadas não são contempladas), que são propagadas implicitamente. Dessa maneira, não é necessário passar o contexto da transação explicitamente como um parâmetro, o Container realiza essa tarefa para o cliente.

Enterprise Java Beans e EJB Container simplificam bastante o gerenciamento da transação realizando as tarefas que antes eram de responsabilidade da aplicação, como: criação do objeto da transação, inicialização da transação explicitamente, armazenamento do contexto da transação, realização de aceite da transação. Dessa forma, as responsabilidades do desenvolvedor diminuem bastante no quesito do controle da transação. Diminuindo, também, as chances de que algum erro ocorra, principalmente em ambientes distribuídos.

\section{Transações gerenciadas pelo EJB X transações gerenciadas pelo Container}

Quando um EJB indica onde as transações serão iniciadas e terminadas nos seus métodos de negócio, este EJB é considerado responsável pelo gerenciamento das suas transações. Quando a responsabilidade do controle das transações é delegada ao EJB Container, o mesmo será responsável por "demarcar" a transação baseado nas instruções do Deployment Descriptor.

Sempre que possível, devem-se utilizar transações gerenciadas pelo Container. Elas requerem menos trabalho por parte do desenvolvedor e são menos suscetíveis a erros.

EJBs que utilizam transações gerenciadas pelo Container possuem atributos de transação associados com cada um de seus métodos ou com um EJB como um todo. $O$ atributo indica ao Container como ele deve gerenciar as transações que envolvem o EJB. Seis diferentes atributos de transação são associados ao EJB:

- Required: Garante que o "trabalho" associado ao método será executado dentro do contexto de uma transação. Se o cliente já possui um contexto de transação, o mesmo será utilizado. Se ele não possui, o Container inicia uma nova transação automaticamente.

- Requires New: É utilizado quando se associa o método com uma transação 
já existente. Garante que o Container vai sempre iniciar uma nova transação.

- Supports: O método do EJB será chamado com a mesma política de transação do cliente, caso ele tenha alguma. Se ele não tiver nenhuma, o contexto da transação será setado para Not Supported, ou seja, não será utilizada uma transação para a chamada do método do EJB.

- Not Supported: O EJB será chamado sem transação. Se o cliente chama o método com o contexto de uma transação, o Container suspende a chamada.

- Mandatory: O EJB requer um contexto transacional. O método do EJB será chamado com a mesma política transacional do cliente, se houver alguma. Se não existir, será levantada uma exceção (javax.transaction.TransactionRequiredException).

- Never: O cliente que chama um método com este atributo de transação não pode ter um contexto de transação associado. Se tiver, o Container lança uma exceção.

Observa-se que na solução disponibilizada pela arquitetura J2EE há o conceito de transação partida (em detalhe na seção 3.2.1.). Entretanto o controle de cada subtransação é delegado completamente para os respectivos componentes do J2EE de modo independente. 


\section{Desenvolvimento da solução}

Após delimitarmos e caracterizarmos os problemas relacionados à replicação e integração assíncrona de instâncias de bases de dados, e descrevermos a bibliografia existente, bem como o estado da arte das implementações atuais, prosseguiremos com a descrição da solução proposta.

Recentemente, os bancos de dados têm apresentado soluções para a realização de transações assíncronas. São exemplos de propostas de soluções genéricas o uso de transações aninhadas e partidas [15] como forma de sincronização de transações conflitantes em banco de dados. A generalização da solução é dificultada principalmente por causa das limitações impostas pelo alto grau de complexidade das aplicações e sua especificidade nas regras de negócio. Por esses motivos, existem dificuldades no tratamento de transações aninhadas e conflitantes. Então, como podemos diminuir a complexidade para permitir o uso de tais transações assíncronas?

Podemos restringir o grau de complexidade das aplicações e sua especificidade nas regras de negócio por meio da delimitação do domínio da aplicação. Uma vez identificado o domínio, podemos parametrizá-lo de modo a restringir o grau de inconsistência das transações assíncronas.

Se o domínio de aplicação for parametrizado com relação à consistência transacional, então é possível automatizar os estados inconsistentes nos processos de sincronismo em banco de dados. A parametrização do domínio de aplicação pode ser realizada segundo critérios estabelecidos por regras de negócio da aplicação. Assim, parametrizando o domínio da aplicação é possível diminuir a classe de complexidade do banco de dados e do processo de sincronização de transações.

Dentro da solução proposta apresentamos o modelo transacional que pressupõe a parametrização do domínio de aplicação. Esse é configurado mediante critérios que dependem do domínio de aplicação. Junto com os parâmetros são gerados os possíveis estados intermediários das transações conflitantes. Estados intermediários estão relacionados à tentativa de reduzir a quantidade de conflitos entre as transações que utilizam o modelo transacional assíncrono. Mais detalhes sobre o modelo transacional podem ser encontrados ainda nesta seção, no item 3.2.

O modelo transacional parametrizado reduz a complexidade do banco de dados pois baseia-se nas regras de negócio comuns às aplicações de um mesmo domínio de aplicação. Os parâmetros definidos pelo modelo transacional são utilizados também no pré-escalonamento das transações durante os processos de sincronismo do banco de dados.

O pré-escalonador é um componente da solução proposta que, baseado nos parâmetros do modelo transacional instanciado, estabelece estados intermediários das transações conflitantes. Além disso, reordena as transações no processo de sincronização de transações assíncronas segundo os parâmetros do modelo transacional. O pré-escalonador de transações utiliza algoritmos que são baseados nos critérios existentes e definidos pelo modelo transacional adotado.

Qual o modelo transacional indicado para uma certa aplicação? Os parâmetros e critérios obtidos pelas regras de domínio da aplicação definirão o modelo transacional. 
Sistemas de um mesmo domínio de aplicação utilizam regras semelhantes. Como conseqüência estabelecem parâmetros comuns para o modelo transacional referente ao mesmo domínio de aplicação.

A parametrização do modelo transacional permite ajustar as regras que melhor atendam à uma determinada aplicação, segundo o domínio de aplicação utilizado. Essa característica de reconfiguração é muito importante pois mesmo em um domínio de aplicação comum, diferentes aplicações podem associar valores distintos às regras utilizadas. A escolha da aplicação ou não de critérios, bem como a ordem de seu uso, são totalmente configuráveis por meio da parametrização do modelo transacional adotado.

O pré-escalonador é reconfigurado dinamicamente para utilizar os parâmetros e critérios válidos pela aplicação segundo o modelo transacional utilizado. Esse dinamismo permite ajustar rapidamente as aplicações às variações e mudanças nas regras do domínio de aplicação, sempre considerando o modelo transacional adotado.

Esta seção encontra-se organizada em duas subseções: "Modelo transacional conceitual ", que descreverá as justificativas da solução proposta e "Implementação do modelo transacional", que detalhará as estruturas e os componentes da solução apresentada.

Já na seção 4, denominada "Exemplo de aplicação do modelo transacional ", descrevemos um sistema cadastral da Secretaria de Estado dos Negócios da Fazenda do Estado de São Paulo (Sefaz-SP), exemplificando diversas situações em que o sistema existente se beneficia das vantagens do uso do modelo transacional.

\subsection{Proposta lógica}

Segundo as hipóteses da solução apresentadas no item "Hipóteses e objetivos da solução", temos uma aplicação servidora localizada no servidor central e várias aplicações que encontram-se localizadas nas várias instâncias nós clientes. A base de dados que armazena as informações do sistema é chamada base de dados da aplicação.

Por questões de simplificação, adotaremos um esquema homogêneo entre as bases de dados nós clientes e servidora. Assim, os problemas relacionados à integração de esquemas não serão alvo em questão. Desejamos focar nosso trabalho no processo de integração de transações assíncronas para bases de dados autônomas.

Para cada aplicação localizada em nó cliente existe uma instância da base de dados da aplicação situada em sua máquina local. Por causa das limitações resultantes do porte da máquina cliente (geralmente máquinas portáteis com pequena capacidade de armazenamento em disco), as bases de dados da aplicação cliente terão replicados em sua estrutura apenas subconjuntos dos dados armazenados na base de dados da aplicação localizada no servidor central.

Não desejamos, com esse trabalho, tratar o modo como a replicação de dados será conduzida entre as bases de dados servidora e cliente. No item "Delimitação e caracterização do problema" referenciamos diversas preocupações que devem fazer 
parte desse processo. Por ora é suficiente saber que os dados encontram-se replicados nas bases clientes e que serão alvo de transações assíncronas.

Desejamos com esta solução proposta viabilizar o uso de banco de dados autônomo para armazenamento de informações e disponibilização de acesso dos dados aos usuários. Nosso intuito é permitir que a utilização dos dados, por meio de operações de leitura e escrita, ocorra mesmo quando na ausência de conexão da aplicação cliente com o restante do sistema.

Iniciando o detalhamento da solução proposta, descreveremos a seguir o modelo transacional conceitual.

\subsection{Modelo transacional conceitual}

A principal hipótese das propriedades ACID [15] é a da curta duração das transações. O sistema de controle de transações foi concebido para ser implementado com transações que duram uma fração de segundo ou, nos piores casos, algumas dezenas de segundos. É claro que a teoria da seriação está correta para transações de qualquer duração, curta ou longa. No entanto, transações longas tendem a tomar conta de recursos do sistema por muito tempo.

Com transações longas, realizando milhares de operações, também aumenta a chance de ocorrência de travamentos. A solução para tais travamentos é abortar e reiniciar uma das transações envolvidas no travamento. Mas abortar e reiniciar uma transação que está sendo executada há horas ou dias não é uma tarefa que pode ser feita levianamente, graças ao seu grande custo computacional.

Em geral, o aborto de transações muito longas tem que ser evitado. Isso quer dizer que, no máximo, estamos dispostos a desfazer apenas um pedaço de uma transação, e não a transação inteira. Isso constitui uma violação do princípio de atomicidade das transações. Além disso, o fato de abortarmos uma porção da transação, e não a transação toda, implica que estaremos liberando bloqueios obtidos pela transação antes do tempo. Isso qualifica uma violação ao princípio de seriação das transações.

Para o tratamento de transações longas temos os conceitos de transações aninhadas e compensatórias encontradas em [17]. Cada um desses modelos propõe um novo critério de escalonamento concorrente.

Entretanto, nossa abordagem pressupõe transações longas num ambiente de multibanco de dados (MBD). As características básicas dos MBDs são a heterogeneidade e a autonomia dos bancos de dados envolvidos.

Dessa forma, é possível que muitos dos BDs componentes de um MBD não possuam nenhum suporte ao controle de dados distribuídos, pois foram concebidos como unidades autônomas e, mesmo após sua incorporação a um MBD, continuarão a ser empregados por aplicações locais, independentes dos outros bancos de dados.

Outra hipótese básica do funcionamento de um banco de dados distribuído convencional é que todos os participantes de uma transação global estão disponíveis durante toda a duração da transação. No entanto, existem aplicações atuais, para as 
quais essa hipótese é violada. Note que, se a transação é longa, fica cada vez mais difícil garantir que todos os BDs participantes dessa transação fiquem conectados à rede durante toda a duração da transação.

Precisamos, portanto, de algum outro método para controlar a concorrência de transações em sistemas heterogêneos e autônomos.

\subsubsection{Transações partidas}

As transações partidas (split transactions) foram propostas originalmente para tratar as transações de durações muito longas, de final indeterminado, em ambientes de CAD [36]. O modelo de transações tradicional sempre supõe que as transações terminam. No entanto, para atividades em que esse final não é vislumbrado num horizonte próximo, o modelo de transações partidas permite que a transação requeira uma operação de partição. A operação de partição divide uma transação em andamento em duas ou mais transações seriáveis. O modelo de transações partidas pode ser aplicado tanto no modelo tradicional de transações simples, como no modelo de transações aninhadas.

A figura1 ilustra a operação de partição executada sobre o modelo de transações aninhadas. Numa primeira etapa, a transação $T_{1}$ ainda está "inteira", ou seja, a transação não foi partida e se comporta como uma transação aninhada normal. Numa segunda etapa, a transação $T_{1}$ requisita uma operação de partição. A transação é então partida em $T_{11}$ e $T_{12}$, e $T_{1}$ não mais executará nenhuma operação. Como $T_{1}$ é uma transação interna, isto quer dizer que nenhuma nova subtransação será iniciada a partir de $T_{1}$.
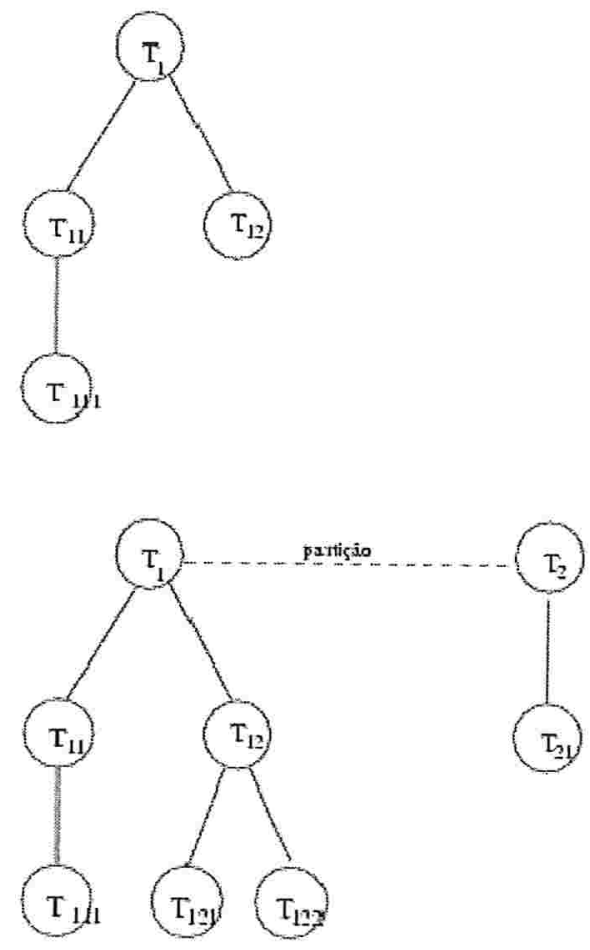

Figura 1 - Transações partidas (parte 1). 


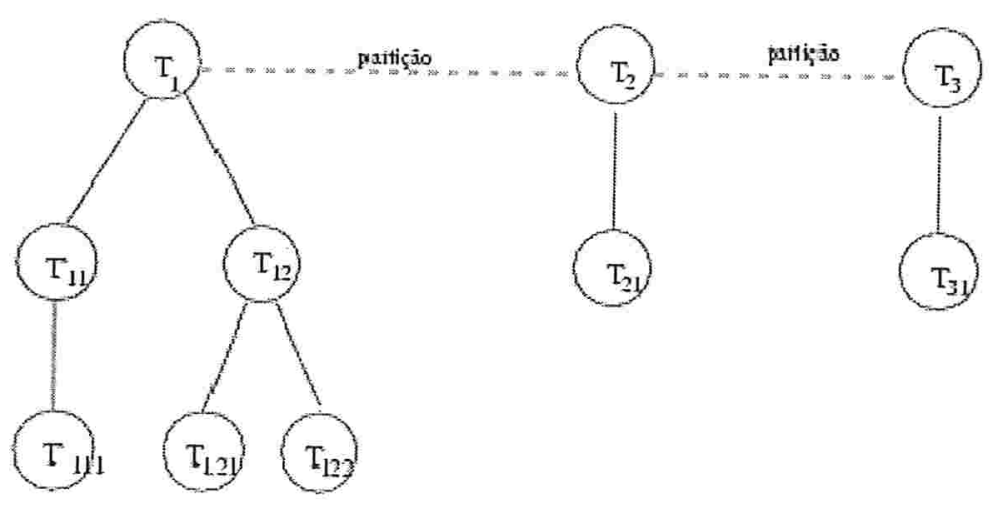

Figura 2 - Transações partidas (parte 2).

Uma nova transação no nível imediatamente inferior a $T_{1}$ somente poderá ser criada a partir de $T_{2}$, gerando $T_{21}$. No entanto, as subtransações descendentes de $T_{1}$ podem ainda "terminar" suas tarefas, e a figura1 ilustra esse fato pela criação de $T_{121}$ e $T_{122}$ após a divisão de $T_{1}$. Em seguida, a transação $T_{2}$ pode requisitar outra partição, e assim criar $T_{3}$. Note que, após a partição de $T_{1}$, algumas de suas descendentes podem abortar. $T_{1}$ não pode mais gerar novas transações, mas ainda pode decidir abortar totalmente.

Nessa concepção é responsabilidade da aplicação decidir se $T_{2}$ e $T_{3}$ devem ser abortadas. Por outro lado, se $T_{3}$ abortar após a confirmação de $T_{1}$ e $T_{2}$, fica também a cargo da aplicação decidir se as suas fases anteriores devem ser compensadas ou não. Ambas as possibilidades são contempladas, e o modelo não nos força a nenhuma delas. Mas note que se optar por não compensar as transações confirmadas, estaremos violando a atomicidade. O fato de encarregar a aplicação de decidir se deve ou não abortar uma determinada transação partida é um problema que queremos diminuir na nossa proposta.

É importante notar que a partição de transações não é equivalente a termos uma transação aninhada hipotética, digamos, $T_{0}$, que é mãe de $T_{1}, T_{2}$ e $T_{3}$. Independentemente de haver compensação ou não, as transações partidas não preservam o isolamento das outras transações no sistema. Uma transação partida comporta-se como uma série de transações seriáveis, não como uma única transação aninhada $T_{0}$.

Essa partição apresenta o seguinte problema: quando, por exemplo, $\mathrm{T}_{1}$ se confirma, seus bloqueios são liberados e podem ser adquiridos por uma outra transação, que, em seguida, se confirma e os libera, para serem então adquiridos por $T_{3}$. Isto jamais aconteceria se a transação não fosse partida, pois os bloqueios de $T_{1}$ passariam para $T_{0}$, e de lá para para $T_{3}$, sem serem "emprestados" a nenhuma outra transação do sistema. Dessa forma, não podemos dizer que a seqüência $T_{1}, T_{2}, T_{3}$ está sendo executada isoladamente das outras transações do sistema.

Por outro lado, é óbvio que a partição de transações permite um grau de concorrência muito maior, ou seja, ao adotarmos transações partidas, estamos adotando um compromisso: sacrificar a independência da transação para obter maior grau de concorrência, sem, com isso, abandonar totalmente a noção de seriabilidade, uma vez que as transações partidas são seriáveis entre si. 
As transações partidas são seriáveis entre si pois são independentes umas das outras. Subtransações descendentes de uma transação partida são dependentes apenas da transações que as originou, mas também mantém a independência entre si. É responsabilidade da aplicação decidir o aborto das transações partidas.

\subsubsection{Partição de transações com parâmetros}

Tendo a transação partida para diminuir a dependência da aplicação, nesse trabalho propomos a criação de dois parâmetros que objetivam automatizar o processo de compensação ou aceite das transações partidas. $a_{k(k=1, n)}$ :

Seja uma transação T partida em $t_{i(i=1, n)}$, rotulada com os parâmetros $p_{j(j=1, n)} e$ em que:

$$
T=U t_{i} p_{j} a_{k}
$$

$p_{j}$ é a prioridade da transação partida para fins de seriação global pelo préescalonador;

$a_{k}$ é o grau de importância da transação partida $t_{i}$ para finalidade de aceite da transação T em questão.

Os índices $i, j$ e $k$ apresentados acima denominam valores numéricos que variam de 1 a $n$. O intuito em diferenciá-los na fórmula é possibilitar a reconfiguração dinâmica dos índices como propõe o modelo conceitual.

Para cada transação $t_{i}(i=1, n)$, os índices $j$ e $k$ podem ser reconfigurados de forma a representar um outro valor no vetor de prioridades (índice $j$ ) e no vetor de graus de importância (índice $k$ ).

\subsubsection{Novo critério de escalonamento}

Uma ordem parcial clássica [15] é um conjunto de pares ordenados, respeitando algumas restrições. Se representarmos a ordem por <, então podemos escrever: $a<b$, $\mathrm{a}<\mathrm{c}, \mathrm{b}<\mathrm{c}$. O fato de $\mathrm{a}<\mathrm{b}$ representa que o evento a ocorreu antes do evento $b$. Já o fato de $b$ e $c$ não estarem ordenados por < representa o fato de que $b$ e $c$ estão ocorrendo concorrentemente. Dessa forma, temos um modelo bem simples e eficaz para representar eventos que ocorrem em série e eventos concorrentes.

Uma ordem parcial (irreflexiva < sobre um conjunto $\Omega$ é uma relação binária em $\Omega$ $x \Omega$ (ou seja, é um conjunto de pares ordenados), representado por $(\Omega ;<$ ), satisfazendo as seguintes restrições:

- a ordem < é transitiva: para todo $x ; y ; z$ pertencente a $\Omega$ se $x<y$ e $y<z$ então $\mathrm{x}<\mathrm{z}$.

- a ordem < é irreflexiva para todo x pertencente a $\Omega$.

Uma ordem parcial pode ser vista como um grafo dirigido; e, mais do que isso, como a ordem parcial é irreflexiva concluímos que o grafo dirigido deve ser acíclico.

Em nossa proposta essa ordem parcial é revista com o conceito de prioridade $p_{j}$. Portanto, para a nova seriação, caso haja inversão de execução de transações por 
causa do parâmetro $p_{j}$ (prioridade) entre duas ou mais transações com datas de submissão conflitantes com tal prioridade, duas opções podem acontecer:

- execução da transação $t_{i}$ : nesse caso, as conseqüências da perda da seriação serão avaliadas pelo domínio de aplicação, conforme exemplo da seção 4.5 .

- aborto da transação $t_{i}$ : nesse caso, a seriação é mantida em detrimento da perda da transação $t_{i}$ com menor prioridade.

Assim, para estabelecer a ordem parcial, não basta apenas ter o parâmetro da data de submissão da transação mas também o parâmetro $p_{j}$ de prioridade transacional que prevalece sobre a data de submissão.

\subsubsection{Novo critério de fim de transação}

No conceito clássico de transação temos a condição de aborto ou finalização da transação. Em nossa proposta tal conceito é substituído por um parâmetro $\Phi$ que descreve o grau de aceite global da transação $\mathrm{T}$ em questão. Para ponderar a importância de cada subtransação $t_{i}$ gerada com a partição da transação $T$, utilizamos $a_{k(k=1, n)}$, que se refere ao grau de importância de cada transação $t_{i}$.

Esse parâmetro $a_{k}$ descreve a importância de cada $t_{i}$ para o aceite da transação T. Assim podemos redefinir o conceito de fim de transação de acordo com o parâmetro $\Phi$. Pode-se observar que, nessa definição, algumas transações $t_{i}$ podem não ser finalizadas, entretanto a transação $T$ pode ser considerada finalizada se $\Phi$ (grau de aceite global da transação T) for atingido. Esta situação é ilustrada na seção 4.3.

\subsection{Implementação do modelo transacional}

Após apresentar os conceitos relacionados ao modelo transacional proposto, prosseguiremos com o detalhamento da implementação de seus componentes. Entendemos como componentes as estruturas, bases de dados e processos necessários para viabilização da implementação do modelo transacional conceitual. A figura a seguir ilustra a localização dos componentes do modelo transacional.

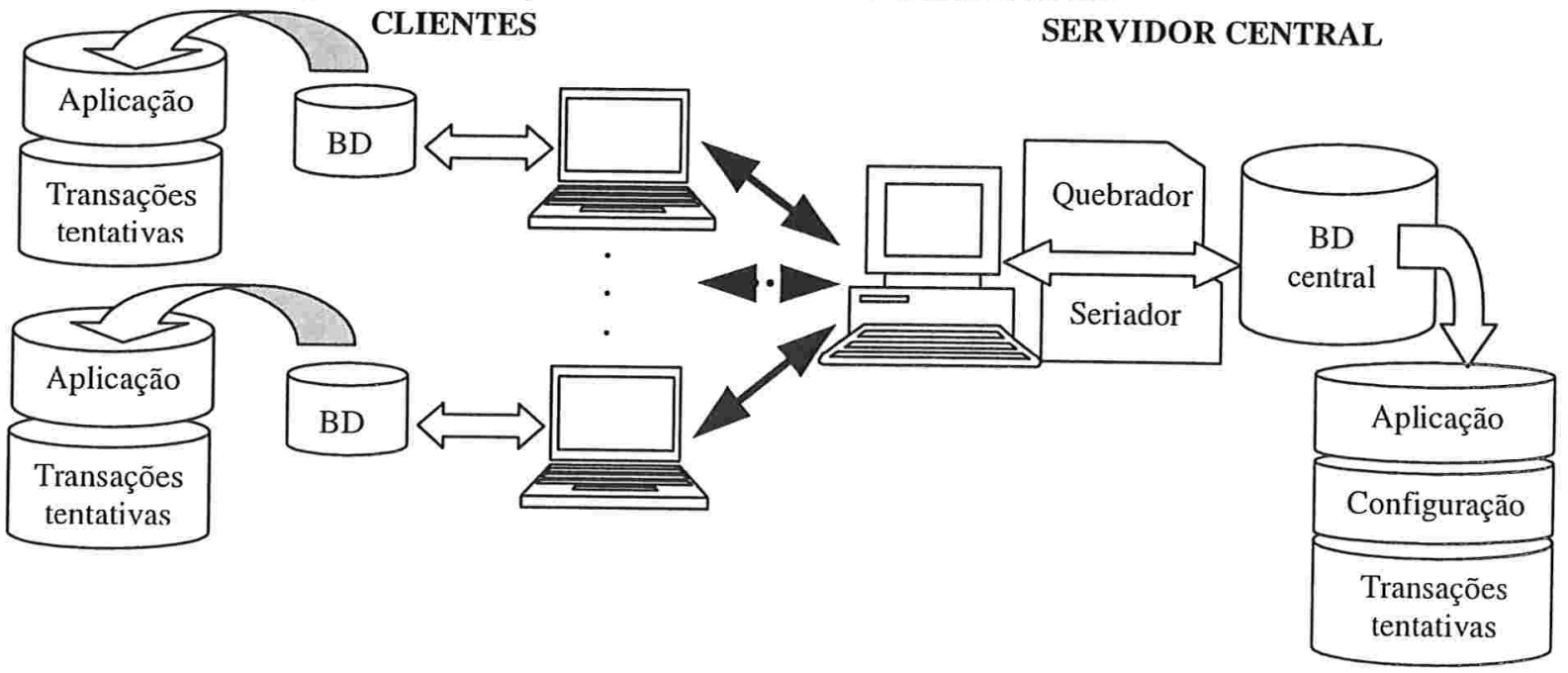

Figura 3 - Componentes do modelo transacional segundo as aplicações cliente e servidora. 
Serão descritos a seguir os principais componentes para a implementação do modelo transacional conceitual :

- Base de dados de transações tentativas: responsável pelo armazenamento das transações tentativas realizadas pelos clientes. Possui instâncias nos nós clientes e servidor. Em sua versão servidora é realizada a seriação das transações.

- Base de dados de configuração: armazena os parâmetros que representam o comportamento do modelo transacional instanciado. O comportamento do modelo transacional está relacionado às regras de negócio adotadas.

- Quebrador de transações: realiza a quebra transacional das transações armazenadas na versão servidora da base de transações tentativas, segundo o comportamento parametrizado na base de configuração do modelo transacional instanciado.

- Pré-escalonador (seriador): reclassifica as transações existentes na versão servidora da base de transações tentativas, segundo o comportamento do modelo transacional instanciado. Realiza a seriação das transações tentativas cliente baseado nessa reclassificação.

Após uma breve introdução dos componentes do modelo transacional conceitual, prosseguiremos com uma descrição mais detalhada dos mesmos.

\subsubsection{Base de dados de transações tentativas}

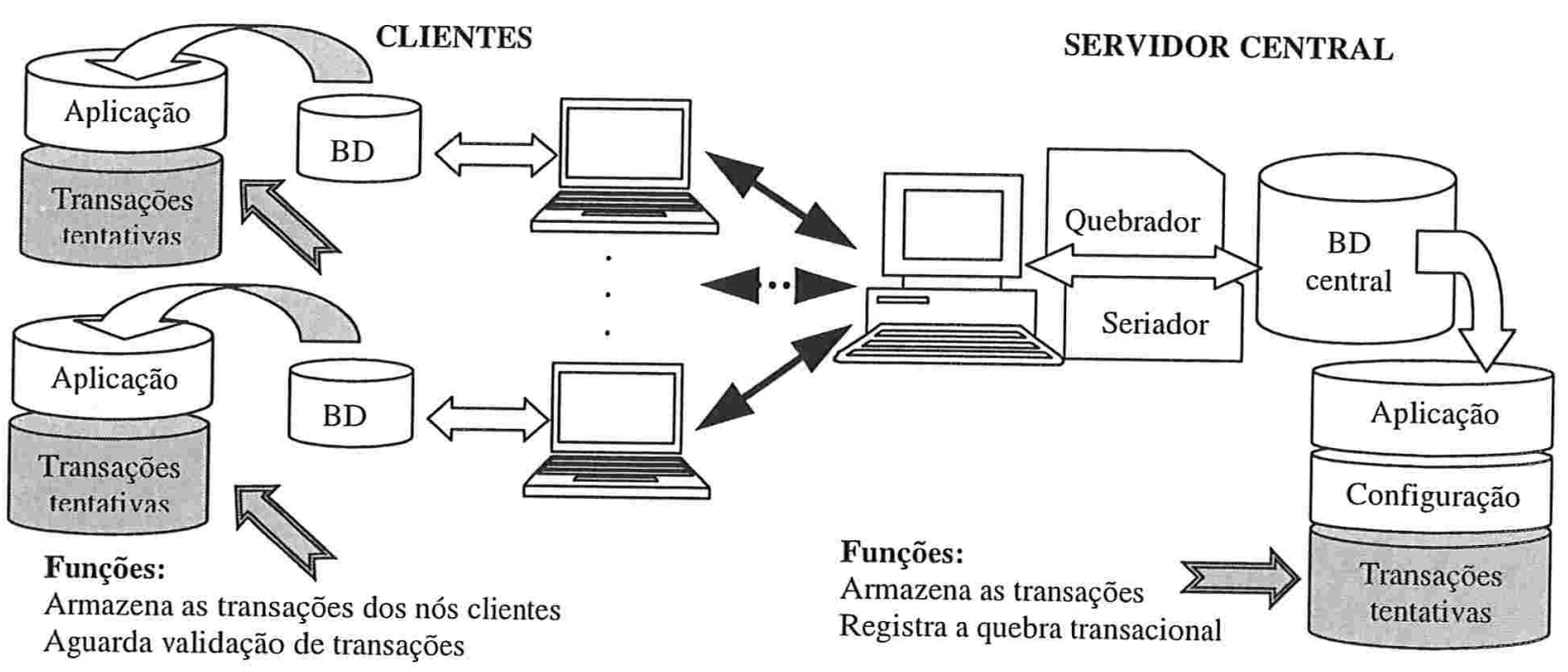

Figura 4 - Bases de transações tentativas localizadas no servidor central e nos nós clientes.

A base de dados de transações tentativas é um dos principais componentes para implementação do modelo transacional conceitual. Essa base de dados tem como função o registro e controle das transações / solicitações clientes. 
As solicitações clientes devem ser representadas na instância da base de transações tentativas, localizada no nó cliente que originou a transação, para posteriormente serem submetidas ao sistema para aceitação. O conceito de transação tentativa [4] é aplicado às solicitações que permanecem na situação de pendência até serem aceitas ou rejeitadas pelo sistema.

Todas e quaisquer solicitações realizadas pelos clientes somente poderão ser consideradas válidas após serem aceitas pelo sistema. Antes disso, são consideradas transações tentativas e podem ser desfeitas localmente, sem representar inconsistência com relação à base de dados global.

Para recepcionar e controlar as solicitações clientes é necessária a existência de uma instância da base de transações tentativas localizada no servidor central de aplicação. Essa instância central será responsável pela recepção de todas as solicitações clientes, e nela serão processadas todas as solicitações do sistema.

Será na instância servidora da base de transações tentativas que as transações dos nós clientes serão analisadas pelo quebrador de transações que poderá, dependendo do comportamento transacional adotado na base de configuração, realizar a quebra transacional. Mais detalhes a respeito desse processo podem ser encontrados no item 3.3.3 referente ao quebrador de transações.

É também na base de transações tentativas centralizada que o pré-escalonador, por meio dos parâmetros da base de dados de configuração, realizará a reclassificação das transações segundo o perfil transacional instanciado. Após essa classificação, será realizada a seriação das transações conforme as regras definidas na base de configuração. Mais detalhes a respeito do processo de classificação e seriação de transações são descritos no item 3.3.4 referente ao pré-escalonador.

A estrutura da base de transações tentativas depende única e exclusivamente do perfil transacional instanciado. O perfil transacional referencia o tipo de dado que a aplicação utiliza, e está relacionado ao setor de atuação da organização. Por exemplo, na seção "Exemplo de aplicação do modelo transacional " descrevemos um exemplo de uma aplicação de unificação cadastral. Assim, o modelo transacional instanciado utiliza o perfil transacional relacionado às aplicações de controle cadastral.

Dessa forma, a estrutura da base de transações tentativas registra as informações relacionadas ao perfil transacional instanciado. Sabemos que diferentes corporações que atuam em um mesmo nicho de mercado podem utilizar o mesmo perfil transacional, porém com diferentes configurações para ajustar aos interesses e às necessidades da organização.

Após uma transação ser seriada pelo pré-escalonador, este atualiza o estado da mesma na base de dados de transações tentativas. Entendemos como atualização de estado a mudança da situação da transação de modo a representar, por exemplo, sua aceitação, e assim permitir a diferenciação em relação às demais transações registradas na base de dados de transações tentativas. Fazem parte dos possíveis estados de transações as situações: OK (transação aceita), NOK (transação negada), PDT 
(transação pendente ou aguardando seriação) e \%OK (transação parcialmente aceita).

O resultado do processo de seriação das transações deve ser propagado aos clientes para que estes tomem conhecimento do andamento de suas transações e das demais que conflitam com seu conjunto de dados replicados. A aceitação, negação ou aceitação parcial de uma transação tem reflexo nos dados das bases de dados de transações tentativas existentes nos nós clientes, e nas informações da base de dados da aplicação.

Os valores modificados pelas transações aceitas são atualizados na base de dados da aplicação, e a mudança de estado é refletida nas bases de dados de transações tentativas (base servidora e base do cliente que originou a transação).

Com esse atributo estado da transação controlamos as situações intermediárias de modo a rever o conceito de término de transação conforme visto na seção 3.2.

Sabendo que conjuntos de dados comuns podem ser replicados em mais de uma instância cliente, como garantir que as bases de dados da aplicação permaneçam sincronizadas? Essa questão é primordial para a confiabilidade das bases de dados. Como dissemos anteriormente, pretendemos oferecer com esta proposta a maior disponibilidade possível do sistema e, conseqüentemente, dos dados aos nós clientes.

As transações realizadas pelos clientes sobre as instâncias locais da base de dados da aplicação são representadas na base de dados de transações tentativas locais, para, posteriormente, serem transmitidas à base de dados de transações tentativas do servidor central e então serem particionadas pelo quebrador de transações e classificadas pelo pré-escalonador. Após esses processamentos as transações poderão ser aceitas pelo processo de seriação, sendo realizada a atualização da base central de dados da aplicação.

A não-propagação das transações aceitas resulta em desatualização das instâncias cliente que apresentam dados comuns às transações seriadas.

Através da comparação entre os estados da base de dados da aplicação cliente e a base de dados da aplicação servidora é possível identificar quais réplicas são sobrepostas. Quando existirem diferenças de estados, podemos afirmar que a base de dados da aplicação cliente utilizou para essa transação uma versão desatualizada do dado, isto é, uma informação com conteúdo que não representa o valor correto no sistema.

Baseadas nessa situação, duas opções podem ser tomadas. Dependendo dos valores apresentados e do grau de diferença dos estados, a transação cliente pode prosseguir com o processo de validação de solicitação, ou a rejeição da transação pode ser realizada diretamente.

Não desejamos que os nós clientes sejam penalizados pela latência de comunicação com o sistema. Assim, adotamos a estratégia de validar as transações clientes mesmo que estejam com valores conflitantes e insuficientes para realizar a aceitação total das transações. 
O sincronismo entre as bases de dados ocorrerá no momento da resposta após o processo de classificação e seriação das transações pelo pré-escalonador. Com o resultado do processamento da transação, a base de dados de transações tentativas clientes será atualizada com a situação atual da transação. Além da situação ou do estado da transação cliente, os dados atualizados da base de dados da aplicação central que estiverem relacionados aos dados manipulados pela transação cliente também deverão ser atualizados na réplica cliente da base de dados da aplicação.

Realizando, dessa maneira, a atualização das réplicas clientes da base de dados da aplicação, todas as novas transações já visualizarão os valores atualizados do dado no sistema. Se, por acaso, as transações locais existentes excederem os limites atuais do banco de dados, restrições podem ser impostas às novas transações locais de forma a evitar maiores inconsistências de dados e falsas expectativas quanto à disponibilidade de recursos durante o processo de validação no servidor central.

Os resultados do processo de seriação do pré-escalonador sobre a base de dados de transações tentativas central permitem que os clientes, ao se reconectarem ao sistema, realizem uma simples consulta com o intuito de identificar possíveis dados desatualizados. Essa consulta é baseada nas transações pendentes do nó cliente e, ao se obter os resultados da seriação das transações, os dados envolvidos e atualizados podem ser então propagados à base de dados da aplicação do nó cliente.

Esse processo é rápido e eficiente pois evita o tráfego desnecessário de dados com versões idênticas entre as bases de dados da aplicação servidora e cliente. Tal característica é muito importante quando as limitações do canal de comunicação são maiores e mais severas.

Essa característica de propagação controlada evita processos de replicação demorados que realizam a reprodução integral da instância de base de dados da aplicação no nó cliente. Dependendo da qualidade do canal de comunicação, esse processo pode ser controlado de modo a trafegar informações apenas nos momentos que as transações não estejam utilizando o canal.

Estaremos omitindo certos detalhes da propogação de transações entre os nós clientes e servidor pois desejamos com este trabalho focar as etapas de validação e seriação de transações assíncronas conflitantes.

Mais informações sobre a base de transações tentativas serão apresentadas na seção "Exemplo de aplicação do modelo transacional ", no item referente à "Base de dados de transações tentativas". 


\subsubsection{Base de dados de configuração}

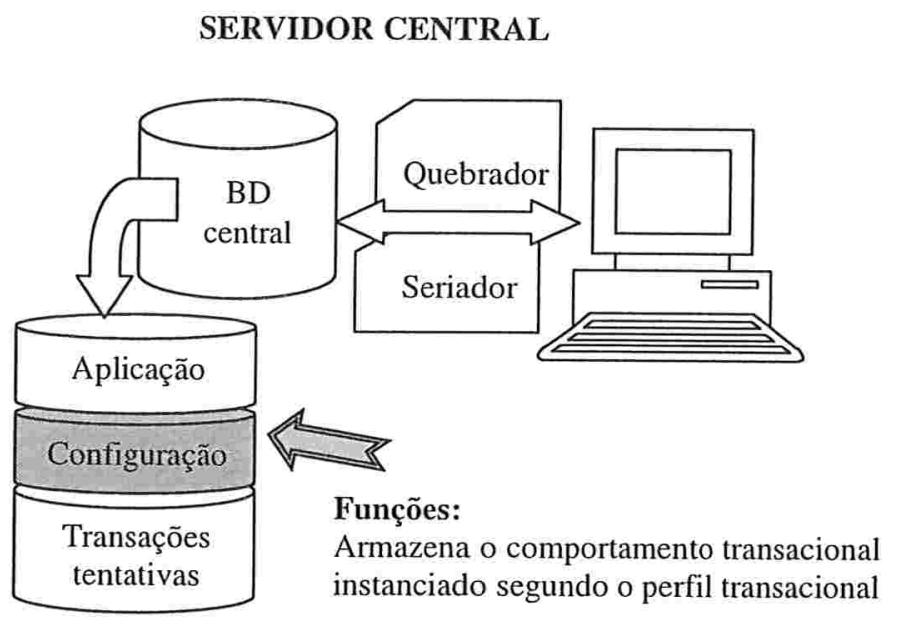

Figura 5 - Base de dados de configuração localizada no servidor central.

Outro importante componente do modelo transacional é a base de dados de configuração. Nela está representada a abstração do comportamento transacional segundo o domínio de aplicação utilizado. Seu propósito está implicitamente ligado à composição da prioridade das transações e do grau de aceite conforme modelo transacional conceitual apresentado no item 3.2.

As regras de negócio do domínio de aplicação representam as funcionalidades, consistências, validações e permissões pertinentes ao uso e manipulação dos dados existentes em uma organização. Diferentes organizações utilizam diferentes regras de negócio. Dependendo do nicho de mercado ou setor de atuação, semelhanças são observadas entre o conjunto de regras de negócio utilizado pelas organizações.

Baseado nessa semelhança entre as regras de negócio, identificamos comportamentos equivalentes entre organizações que atuam em um mesmo setor. A diferenciação observada nesse caso baseia-se na ordem de importância relacionada ao uso ou aplicação de algumas regras de negócio adotadas.

Assim, deseja-se representar o comportamento transacional relacionado às regras de negócio de modo a refletir as necessidades das organizações. Tal representação é realizada por meio da base de dados de configuração.

A base de dados de configuração é a base responsável pela representação do comportamento transacional. Esta base encontra-se localizada somente no servidor central por causa de seu envolvimento com os demais processos servidores, tais como o processo de quebra transacional realizado pelo quebrador de transações e o processo de reclassificação e seriação de transações realizado pelo pré-escalonador (seriador).

A estrutura da base de dados de configuração deve permitir a parametrização do comportamento transacional instanciado. Sabemos que organizações de um mesmo nicho de mercado utilizam regras de negócio semelhantes. A diferenciação em alguns 
casos ocorre na importância associada a uma regra dentro do contexto organizacional de uma corporação, o que reflete em alterações no comportamento transacional.

Configurações semelhantes de comportamentos transacionais representam perfis transacionais equivalentes para organizações de um mesmo setor ou nicho de mercado.

Entendemos como perfil transacional o tipo, modelo e escopo das transações realizadas por uma organização. Por exemplo, um comércio atacadista tem suas transações baseadas em pedidos de venda com forte vínculo ao sistema de controle de estoque. Já um sistema cadastral que realiza validação de dados cadastrais tem seu foco na conferência de informações e no cruzamento de dados com outras fontes de informação.

A representação do comportamento transacional na base de dados de configuração está relacionada ao perfil transacional utilizado pela organização. As regras de negócio que serão representadas no sistema ajudam a definir o perfil transacional conforme as características definidas pela organização.

Cada perfil transacional instanciado baseia-se em regras e critérios que são representados na base de dados de configuração para atender aos interesses da organização. Organizações de um mesmo nicho de mercado podem utilizar o mesmo perfil transacional, porém com diferentes configurações para ajustar às suas necessidades de negócio.

O modelo transacional instancia o perfil transacional de uma corporação através da representação no comportamento transacional das regras de negócio adotadas pela organização.

Mas como representar e atender às variadas situações existentes? Uma forma de reduzir o escopo dessa solução é identificar perfis transacionais comuns entre as corporações. Verificamos uma forte correspondência entre as regras de negócio utilizadas por organizações de um mesmo perfil transacional. Esse modelo proposto permite a parametrização do comportamento transacional de forma a melhor adequar as necessidades das corporações. Com isso podemos ajustar e flexibilizar o uso das regras de forma dinâmica, propiciando grande dinamismo ao modelo transacional.

A reutilização de um perfil transacional existente reflete em economia de tempo quando outra organização que apresenta o mesmo perfil transacional deseja utilizar o mesmo modelo transacional. Os ajustes necessários para adequação à nova realidade da organização são realizados através da parametrização e configuração do comportamento transacional representado no modelo transacional. Para que o perfil transacional instanciado atenda da melhor maneira os requisitos da organização, a inclusão de novas representações de regras de negócio é permitida e desejada.

As regras de negócio definem e caracterizam o domínio de aplicação. Como configurar e representar o comportamento transacional das regras de negócio na base de configuração? Diversas são as formas de representação das regras de negócio nessa base de dados. Dependendo do nicho de mercado ou setor de atuação da corporação 
que instanciar o modelo transacional, diferentes tipos de regras serão utilizados.

A seguir detalharemos os principais conceitos que devem ser representados na base de dados de configuração para viabilizar o uso do modelo transacional. Ressaltamos que tais conceitos são parte da metainformação que representa o comportamento transacional segundo o perfil transacional adotado.

Para facilitar a compreensão de tais conceitos, procuramos agrupá-los conforme os principais processos do modelo transacional:

- Quebrador de transações:

- Mapeamento da quebra transacional

- Tipos de transações particionadas

- Pré-escalonador (fase de classificação):

- Origem e destino de transações

- Pesos transacionais

- Prioridade da transação

- Pré-escalonador (fase de seriação):

- Porcentagem de aceite

- Grau de aceite

\section{Parâmetros da base de configuração utilizados pelo quebrador de transações}

Os conceitos a seguir apresentados fazem parte da base de configuração e são utilizados como parâmetros pelo quebrador de transações no processo de quebra transacional.

\section{Mapeamento da quebra transacional}

Um importante conceito introduzido pelo modelo transacional é a quebra das transações. Dependendo do conjunto de regras de negócio existente, uma organização tem interesse em atender melhor ou com maior intensidade a uma determinada transação ou dado de um determinado cliente.

Conforme o modelo e perfil transacional adotado, a quebra da transação ocorrerá por diferentes motivos. Entendemos que, em se tratando de bancos de dados autônomos, o grau de conflito e conseqüentemente a quantidade de transações negadas é numerosa. Assim, não é desejado que transações realizadas em bases de dados, quando em momentos de desconexão, sejam negadas ou não atendidas em razão de conflitos existentes entre réplicas de dados.

Visualizamos a quebra das transações como uma forma de atender, mesmo que parcialmente, às várias transações conflitantes, mas sempre considerando para isso as regras de negócio representadas no modelo transacional em questão.

A base de configuração armazena as informações que auxiliam no processo de partição de transações conforme o perfil transacional adotado. Para cada perfil transacional a base de configuração registra um conjunto de regras diferentes que condizem com o tipo de aplicação existente. Assim, o mapeamento das informações 
para quebra transacional depende do domínio de aplicação.

A quebra transacional pode ocorrer de diversas formas. Uma delas é baseada no conjunto de dados envolvidos com as transações. Um perfil transacional que se beneficia desse tipo de mapeamento são as aplicações cadastrais que realizam a validação de dados.

Nesse perfil, a estrutura da base de configuração necessária para mapear a quebra transacional deve permitir a representação do conjunto de dados que pode ser alvo de partição ou particionável. A tabela abaixo mostra a representação dos conjuntos particionáveis na base de configuração.

\begin{tabular}{|c|l|}
\hline Conjunto de dados particionáveis & Dado cadastral \\
\hline A & $\mathrm{a}_{1}, \ldots, \mathrm{a}_{\mathrm{x}}$, onde $(\mathrm{x}=1, \mathrm{n})$ \\
\hline B & $\mathrm{b}_{1}, \ldots, \mathrm{b}_{\mathrm{y}}$, onde $(\mathrm{y}=1, \mathrm{n})$ \\
\hline C & $\mathrm{c}_{1}, \ldots \mathrm{c}_{\mathrm{z}}$, onde $(\mathrm{z}=1, \mathrm{n})$ \\
\hline D & $\mathrm{d}_{1}, . . \mathrm{d}_{\mathrm{w}}$, onde $(\mathrm{w}=1, \mathrm{n})$ \\
\hline
\end{tabular}

Tabela 1 - Estrutura da base de configuração para mapeamento dos conjuntos de dados particionáveis.

O conjunto de dados particionáveis denominado $A$ agrupa os dados cadastrais $a_{1}, . ., a_{x}$, onde $(x=1, n)$. Todo agrupamento reúne os dados cadastrais que são semanticamente relacionados conforme o perfil transacional adotado. Assim, dados corrrespondentes a uma mesma informação cadastral são representados em um mesmo conjunto de dados.

Os dados cadastrais semanticamente relacionados encontram-se agrupados em conjuntos, podemos então quebrar as transações baseando-se nos agrupamentos que estaremos isolando em subtransações os conjuntos de dados não relacionados. Realizando o mapeamento de conjuntos de dados particionáveis, o perfil transacional de aplicação cadastral auxilia o processo de quebra transacional.

O processo de quebra transacional está completo quando a estrutura da base de configuração no perfil transacional de aplicação cadastral realiza o mapeamento das transações conforme os conjuntos de dados particionáveis.

Observe na tabela abaixo o mapeamento dos tipos de transações possiveis com os conjuntos de dados particionáveis. Cada tipo de transação pode realizar a quebra transacional de forma diferente, baseando-se em distintos conjuntos de dados. Utilizamos a denominação $R, S$ e $T$ para indicar diferentes tipos de transações.

\begin{tabular}{|c|c|}
\hline Tipo de transação & Conjunto de dados particionáveis \\
\hline $\mathrm{R}$ & $\mathrm{A}, \mathrm{B}$ \\
\hline $\mathrm{S}$ & $\mathrm{B}, \mathrm{C}, \mathrm{D}$ \\
\hline $\mathrm{T}$ & $\mathrm{A}, \mathrm{B}, \mathrm{C}$ \\
\hline
\end{tabular}

Tabela 2 - Estrutura da base de configuração para mapeamento das transações particionadas por conjunto de dados.

O quebrador de transações utiliza as informações dessas estruturas da base de configuração para identificar, conforme o tipo de transação, quais os dados cadastrais que podem ser particionados em subtransações. 
Apresentaremos mais detalhes desse mapeamento de dados no perfil transacional de aplicação cadastral na seção 4, entitulada "Exemplo de aplicação do modelo transacional".

Outro perfil transacional que realiza um processo de quebra transacional diferente do apresentado anteriormente é o de vendas com controle de estoque. Nesse caso, as regras de negócio existentes podem previlegiar que um determinado tipo de cliente tenha prioridade sobre os demais. Assim, os pedidos realizados por esse tipo de cliente têm precedência sobre os pedidos realizados pelos demais clientes. Essa regra serve exclusivamente para considerar os interesses e necessidades da organização na resolução de conflitos entre transações conflitantes. Assim, os clientes pelos quais a organização tem preferência terão seus pedidos atendidos antes dos demais.

Mas como serão tratados os demais pedidos já que o estoque apresenta uma menor disponibilidade de produtos? Para que sejam melhor atendidos, os pedidos posteriores serão aceitos mesmo que parcialmente. Dependendo das regras de negócio existentes, a organização pode preferir atender parcialmente a um cliente em vez de negar totalmente um pedido.

Nesse perfil transacional de aplicação de vendas com controle de estoque, uma forma de suprir a execução parcial do pedido é quebrar a transação inicial em outras subtransações que substituirão a transação original. No caso de um aceite parcial, uma subtransação gerada atenderia parcialmente ao pedido inicial com a quantidade disponível em estoque.

Outra subtransação possível seria uma transação proposta para entrega ou venda dos demais produtos restantes dentro de um período de tempo futuro. Tal subtransação pode utilizar as informações de reposição de estoque previamente agendadas para atender a esses pedidos parciais. Nessa situação, o cliente poderia optar por aceitar a quebra proposta e aguardar pela execução futura das subtransações geradas.

Por causa da quebra de transações proposta pelo modelo transacional, temos a ocorrência de parcialidade de aceitação de transações. Diferentemente dos modelos transacionais convencionais baseados em protocolos síncronos que utilizam principalmente o protocolo two-phase-commit e suas derivações [17]. A quebra de transações ajusta-se mais ao modelo assíncrono utilizado pelos bancos de dados autônomos.

No modelo convencional uma transação só é aceita (fase commit) se todas as réplicas de dados garantirem a consistência atômica da transação. Caso contrário, tal transação é negada (fase abort) devendo ser seriada posteriormente para obter sucesso.

A quebra de transações não é novidade na área de banco de dados. Diferentemente do conceito de transações partidas [15] existentes em bancos de dados distribuídos que ocorrem para execução de transações nas várias bases de dados existentes, a quebra realizada no modelo proposto serve para aumentar as chances de aceitação das transações conflitantes baseando-se nas regras do domínio de aplicação.

Dependendo do grau de sobreposição existente entre as várias instâncias de 
bases de dados clientes, pode ocorrer um aumento na rejeição das transações tentativas, resultando em transação desfeita nos nós clientes. A quebra transacional auxilia na redução da quantidade de transações rejeitadas por intermédio do aumento na aceitação das subtransações geradas com a quebra, permitindo uma parcialidade no aceite das transações origens, evitando que estas sejam totalmente negadas, conforme visto na seção 3.2.4. A eficácia de tais propostas depende das configurações do modelo e perfil transacional utilizados pela organização.

Assim, como conseqüência do uso da quebra de transações e da parcialidade de aceite temos um aumento na aceitação de transações originalmente conflitantes e uma redução na quantidade de negação de pedidos.

Relacionado com o processo de quebra transacional realizado pelo quebrador de transações apresentamos a seguir dois tipos de transações particionadas que podem surgir conforme o perfil transacional adotado.

\section{Tipos de transacões particionadas}

Relacionaremos os dois tipos de transações particionadas que auxiliam na redução da quantidade de conflitos entre as transações que utilizam o modelo de sincronização assíncrono $[15,17]$.

Baseados nas características de parcialidade e quebra transacional, temos dois tipos de transação particionadas, conforme o perfil transacional da aplicação de vendas com controle de estoque.

Transação substituta: Temos a ocorrência desse tipo de transação quando o aceite de uma transação, no momento de sua seriação, não pode ser realizado completamente. Fundamentado no conceito de quebra transacional proposto pelo modelo transacional, a transação é particionada em duas subtransações, uma contendo a parte aceita da transação origem e outra referente à parte não-aceita.

O termo substituta deriva do fato de as subtransações serem geradas sempre que uma transação permite aceitação parcial. As novas subtransações permanecem então vinculadas à transação origem, possibilitando a esta a associação da porcentagem de aceite referente às várias subtransações geradas e aceitas conforme formalizado no item 3.2.4.

O nó cliente recebe como resposta de uma solicitação parcialmente aceita as duas novas subtransações geradas. Note que as subtransações não-aceitas podem ser ressubmetidas ao sistema para um novo processo de seriação e assim sofrerem outras quebras transacionais originando novas subtransações.

Transação condicional: Semelhante à transação substituta que apresenta parcialidade na aceitação de transações, a quebra transacional somente será realizada na transação condicional após a confirmação do nó cliente que originou a transação. Entendemos que nessa proposta a não-aceitação da transação resulta em uma negação que pode ser desfeita considerando-se os novos limites existentes na base de dados da aplicação central. Diante dessa nova visão da base, a ressubmissão com os novos valores pode ser realizada para ser então novamente seriada pelo servidor central. 
Para auxiliar na redução da quantidade de ressubmissões entre clientes e servidor, o modelo proposto permite a configuração de um limite mínimo necessário para a aceitação das transações condicionais. Esse limite mínimo associa às transações uma porcentagem condicional, que corresponde à quantidade mínima a ser atendida para que uma transação seja aceita, sem a necessidade de confirmação pelo cliente origem.

O termo transação condicional origina-se da porcentagem condicional de aceitação associada às transações e necessária à direta aceitação das transações condicionais que respeitam os limites predefinidos pelos clientes.

A diferença entre os dois tipos propostos está relacionada à aceitação parcial direta (sem limite inferior ou confirmação / ressubmissão) e a controlada. O modelo de transação condicional se ajusta bem aos variados tipos de aplicações existentes no mercado pois quantidades inferiores às obtidas pela porcentagem condicional podem inviabilizar a aceitação da transação por parte dos clientes. O modelo de transação substituta também se adapta bem a diversas situações reais nas quais a aceitação parcial é desejada independentemente das quantidades (porcentagens) aceitas.

Outra grande diferença entre os tipos de transações que propomos é a confirmação de transações para ressubmissão. Tal opção só ocorre na transação condicional pois na transação substituta as quantidades aceitas independem de limites mínimos. Dependendo das porcentagens condicionais utilizadas nas transações condicionais (valores baixos), pode-se simular um comportamento equivalente às transações substitutas, isto é, as transações são sempre aceitas por mais distantes que sejam os valores aceitos na seriação.

Os novos tipos de transações baseiam-se no princípio da parcialidade de aceitação de transações. O modelo transacional apresentado na solução proposta utiliza - conceito de quebra transacional para diminuir a quantidade de conflitos entre solicitações conflitantes e aumentar a aceitação (parcial ou não) de transações que utilizam bancos de dados autônomos com seriação assíncrona.

Mais detalhes a respeito do processo de quebra transacional podem ser obtidos no item 3.3.3, denominado "Quebrador de transações".

Continuando com a descrição das informações da base de configuração, prosseguiremos com o detalhamento dos parâmetros envolvidos com o componente préescalonador. Dividimos os parâmetros da base de configuração utilizados pelo préescalonador em duas partes, uma relacionada à fase de classificação de transações e outra relacionada à seriação de transações após a etapa de classificação.

\section{Parâmetros da base de configuração utilizados pelo pré-escalonador (fase de classificação)}

Detalharemos agora os parâmetros da base de configuração utilizados pelo préescalonador na etapa de classificação de transações. Tal processo de classificação ocorre nas transações armazenadas na versão servidora da base de transações tentativas. Neste momento, o processo de quebra transacional já foi realizado, e as transações que podem ser alvo do processo de classificação são as subtransações 
geradas pela quebra transacional mais as transações clientes que, por algum motivo, não sofreram partições pelo quebrador de transações.

\section{Origem e destino de transações}

Este conceito mapeia as informações relacionadas à origem e ao destino das transações registradas na base de transações tentativas. Dependendo das regras de negócio vigentes em uma organização, esta pode ter interesse em atender melhor às transações de um determinado tipo de cliente do que de outros. Assim, a origem da transação pode influenciar na ordem de classificação das transações.

Dependendo do perfil transacional adotado, podemos entender como destino da transação o local onde será finalizada. Por exemplo, no perfil transacional da aplicação de venda com controle de estoque, o destino da transação está relacionado à localização do comprador de determinada mercadoria que foi comercializada por um vendedor de certa cidade. Nesse caso, se existir interesse da organização em atender bem esse comprador, especificamente, ou os compradores de uma determinada região que a empresa tem interesse em expandir, a prioridade é influenciada de modo a refletir tal interesse.

$\mathrm{Na}$ forma de representar esses conceitos na base de configuração é criar estruturas capazes de classificar os tipos de cliente, a operação, a localização, os dados envolvidos, ..., e o fator que indica a relevância de tais informações para o cálculo da prioridade das transações ${ }^{5}$, conforme visto na seção 3.2.2. Abaixo representamos um esboço da estrutura imaginada baseada no perfil transacional da aplicação de venda com controle de estoque.

\begin{tabular}{|l|l|l|l|l|}
\hline Tipo de cliente & Operação & Localização & Produtos & Fator de relevância \\
\hline Gerente & Venda & Até $100 \mathrm{~km}$ & Todos & Alto \\
\hline Supervisor & Venda & Até $80 \mathrm{~km}$ & Todos & Médio \\
\hline Vendedor & Venda & Até $40 \mathrm{~km}$ & Todos & Baixo \\
\hline
\end{tabular}

Tabela 3 - Estrutura da base de configuração para representação da origem e destino das transações.

O fator de relevância é um índice que representa a importância de um determinado conceito no cálculo da prioridade das transações. Assim, cada conceito possui um fator de relevância próprio. A tabela acima apresentada ilustra a representação do fator de relevância referente ao conceito de origem e destino das transações.

Mais detalhes a respeito da prioridade das transações serão apresentados a seguir. Antes, porém, iremos detalhar o conceito de pesos transacionais que também contribuem para o cálculo da prioridade das transações, visto na seção 3.2.2.

\section{Pesos transacionais}

Peso transacional é outro conceito importante que influencia diretamente no processo de classificação de transações pelo pré-escalonador. Os pesos constituem um

\footnotetext{
5 O conceito prioridade das transações representa a prioridade das transações partidas para fins de seriação global pelo pré-escalonador.
} 
novo fator de relevância que participa do cálculo da prioridade das transações para efeito da classificação realizada pelo pré-escalonador.

Entendemos que, dependendo das regras de negócio utilizadas pela organização, as quebras transacionais podem ser realizadas associando pesos diferentes entre as várias subtransações resultantes. Dependendo das subtransações geradas, as organizações podem valorizar certas subtransações atribuindo a estas uma maior importância para a sua aceitação.

Um exemplo que ilustra bem esse conceito de pesos transacionais é um sistema cadastral que faz validação de dados. Dependendo da transação cliente, o quebrador de transações realiza a quebra transacional da transação em várias outras subtransações. Todas as informações modificadas (inseridas, alteradas ou excluídas) devem ser validadas. Suponhamos que, no conjunto de dados modificados, um dado tenha maior importância para a organização do que os demais. A ele é associado um peso transacional muito maior que os outros.

A utilização de pesos transacionais é importante para ajustar a quebra de transações às necessidades representadas pelas regras de negócio adotadas pela organização e representadas pelo perfil transacional, segundo o modelo transacional instanciado.

A parametrização das quebras transacionais utilizadas bem como dos pesos transacionais adotados é permitida pelo perfil transacional. Desejamos propiciar com isso um dinamismo no ajuste às regras de negócio utilizadas pela organização. Convencionamos que a soma dos pesos transacionais das subtransações geradas deve ser igual a $100 \%$. O uso de pesos com soma diferente de $100 \%$ é permitida mas devem ser ajustadas no momento dos cálculos.

Baseado no perfil transacional de aplicação cadastral, apresentamos abaixo uma estrutura da base de configuração para representar os pesos transacionais associados às subtransações geradas pelo quebrador de transações. Representamos também nessa estrutura o fator de relevância que indica a influência do conceito de pesos transacionais no cálculo da prioridade das transações.

\begin{tabular}{|c|c|c|}
\hline Tipo de transação & Conjunto de dados particionáveis & Fator de relevância \\
\hline R & A & Alto \\
\hline R & B & Baixo \\
\hline S & B & Médio \\
\hline S & C & Alto \\
\hline S & D & Baixo \\
\hline T & A & Alto \\
\hline T & B & Médio \\
\hline T & C & Médio \\
\hline
\end{tabular}

Tabela 4 - Estrutura da base de configuração que mapeia os pesos transacionais para efeito do fator de relevância.

A tabela acima referencia a quebra transacional e apresenta o mapeamento dos conjuntos de dados particionáveis segundo os tipos de transações existentes. Apenas associamos a tais mapeamentos o fator de relevância referente ao cálculo da prioridade 
da transação.

Após apresentarmos dois conceitos que são utilizados por meio de fatores de relevância pelo pré-escalonador no processo de classificação das transações, detalharemos a seguir o conceito de prioridade das transações.

\section{Prioridade das transacões}

Segundo o modelo transacional conceitual apresentado em 3.2, a prioridade da transação é o principal conceito para o processo de classificação das transações armazenadas na base de transações tentativas central. É a informação da prioridade da transação que é utilizada para classificar as transações que posteriormente serão seriadas segundo a nova ordenação obtida.

A prioridade da transação é influenciada diretamente pelo comportamento transacional da aplicação. Ela é uma métrica obtida das diversas informações armazenadas na base de configuração. Cada informação constitui um parâmetro (fator de relevância) que irá compor o cálculo da prioridade da transação.

A seguir apresentamos a fórmula do cálculo da prioridade da transação, que baseia-se nos fatores de relevância obtidos dos parâmetros armazenados na base de configuração que influenciam no processo de classificação de transações.

$$
\begin{aligned}
& p_{j}=\sum \sigma_{i(i=1, n)}{ }^{*} K_{i(i=1, n)} \\
& \text { em que } \\
& p_{j} \text { é a prioridade da transação de } j(j=1, n) \text {, } \\
& \sigma_{i} \text { é o fator de relevância do parâmetro } i(i=1, n) \text { transação } j \text {, e } \\
& K_{i} \text { é um índice para ponderar os fatores de relevância } i \text { nas transações } j .
\end{aligned}
$$

A fórmula acima apresentada é utilizada para o cálculo da prioridade da transação, e o resultado obtido pode ser armazenado em uma estrutura na base de transações tentativas central similar à apresentada abaixo.

\begin{tabular}{|c|c|}
\hline Identificador da (sub)transação & Prioridade da transação \\
\hline chave primária & [Alta, Média, Baixa] \\
\hline
\end{tabular}

Tabela 5 - Estrutura da base de transações tentativas central com a classificação das transações segundo as prioridades.

As prioridades da transação acima apresentadas são classificadas em apenas três denominações (alta, média e baixa). Recomendamos a adoção de valores numéricos pois permitem o uso de um intervalo maior de valores, o que ocasiona uma melhor distribuição da transação no processo de classificação.

\section{de seriação) \\ Parâmetros da base de configuração utilizados pelo pré-escalonador (fase}

Detalharemos agora os conceitos da base de configuração utilizados pelo préescalonador na etapa de seriação de transações. Ressaltamos que tal processo ocorre 
nas transações armazenadas na versão servidora da base de transações tentativas e utiliza a ordenação obtida na fase de classificação das transações pelo pré-escalonador.

\section{Porcentagem de aceite}

Após serem classificadas pelo pré-escalonador por meio do uso da prioridade da transação como critério de ordenação das transações, o pré-escalonador realiza a seriação das transações utilizando a classificação obtida. Essa classificação organiza as transações clientes conforme os interesses da organização que encontram-se representados na base de configuração. Mais detalhes a respeito do processo de seriação das transações são apresentados no item 3.3.4.

A porcentagem de aceite é utilizada como métrica para saber o quanto uma transação já foi atendida. O interesse em introduzirmos esse conceito é calcular os aceites parciais de uma transação que sofreu o particionamento pelo componente quebrador de transações.

No modelo proposto uma transação pode ser parcialmente atendida por causa da geração de subtransações. Isso resulta em um conceito chamado porcentagem de aceite. No perfil transacional da aplicação de venda com controle de estoque, um pedido de 100 unidades de um produto poderia ser particionado em outras duas subtransações, uma atendendo 60 unidades no momento e outra subtransação futura com as 40 unidades restantes. Nesse caso podemos entender que a transação origem após a quebra tem uma porcentagem de aceite de $60 \%$. Todo e qualquer exemplo depende única e exclusivamente das regras de negócio representadas pelo perfil transacional instanciado através do modelo transacional.

Os parâmetros armazenados na base de configuração influenciam no cálculo da porcentagem de aceite das transações partidas. Para exemplificar essa influência, consideramos a seguir o conceito dos pesos transacionais.

Os pesos transacionais relacionam-se com a aceitação das transações pois juntos compõem o cálculo da porcentagem de aceite da transação original. Em certos casos, mesmo que a maioria das subtransações geradas pelo quebrador de transações seja aceita, a não-aceitação de uma subtransação que é relevante para a organização resulta em uma baixa porcentagem de aceite.

Assim, mesmo tendo o aceite de todas as demais subtransações geradas referentes aos dados de menor importância, a transação origem ainda pode apresentar uma baixa aceitação em virtude da não-aceitação da subtransação referente ao dado de maior peso.

Mais detalhes a respeito dos pesos transacionais encontram-se na seção 4, denominada "Exemplo de aplicação do modelo transacional".

\section{Grau de aceite}

O pré-escalonador classifica as transações clientes utilizando o comportamento transacional representado na base de dados de configuração, que armazena as regras de domínio de aplicação instanciadas pelo modelo transacional adotado. As transações são seriadas seguindo a ordem estabelecida pelo pré-escalonador. 
Conforme apresentado no item 3.2.4, o grau de aceite global da transação T corresponde à decisão para fins de aborto, compensação ou aceite da transação em questão. No modelo tradicional a condição de finalização da transação está relacionada à aceitação ou ao aborto das transações. No modelo transacional proposto a condição de finalização está relacionada ao grau de aceite global das transações.

O conceito de grau de aceite global da transação T auxilia na definição da finalização das transações pois mensura quanto uma certa transação partida já foi aceita. O grau de aceite define a finalização das transações por meio do grau de importância $a_{k}$ de cada transação partida $t_{j}$. Assim, dependendo do perfil transacional adotado, uma aplicação pode considerar como finalizada as transações que atenderem ao grau de aceite global $\Phi$, mesmo que nem todas as transações $t_{i}$ tenham sido finalizadas.

Dessa maneira, poderemos ter transações que são consideradas finalizadas pela aplicação pois atenderam ao limite mínimo do grau de aceite $(\Phi)$ da transação $T$, mas apresentam subtransações que não foram aceitas.

\subsubsection{Quebrador de transações}

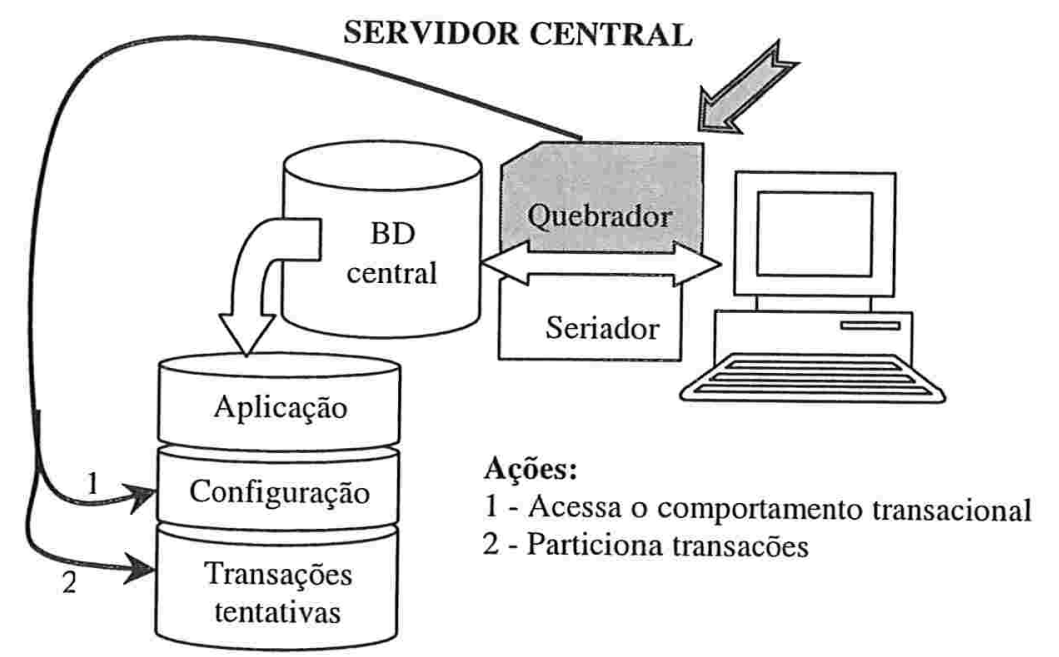

Figura 6-Quebrador de transações localizado no servidor central.

O quebrador de transações é outro importante componente do modelo transacional. Ele realiza a quebra transacional das transações armazenadas na base de transações tentativas central segundo o comportamento parametrizado na base de configuração do perfil transacional instanciado.

Descrevemos anteriormente no item 3.3.2 os parâmetros utilizados da base de configuração pelo quebrador de transações para realizar a quebra transacional. Neste mesmo item, apresentamos exemplos de perfis transacionais, e algumas estruturas de dados necessárias à representação dos parâmetros que compõem o comportamento transacional instanciado. 
O processo de quebra transacional proposto pelo modelo transacional diminui a quantidade de transações partidas negadas por meio da atribuição de parcialidade à aceitação das subtransações geradas. Mais detalhes a respeito da seriação de transações no item 3.3.4.

O quebrador de transações realiza a quebra transacional segundo o perfil transacional instanciado. Para exemplificar mais detalhadamente o processo de quebra transacional, considere o seguinte pseudo-algoritmo de particionamento baseado no perfil transacional de aplicação cadastral.

\section{Pseudo-algoritmo de quebra transacional}

1) Adota o comportamento transacional da base de configuração

a. Acessa as estruturas auxiliares que contêm o mapeamento das quebras

b. Identifica os conjuntos de dados particionáveis

2) Para cada transação não-partida da base de transações tentativas central

a. Analisa os dados envolvidos

b. Mapeia os conjuntos de dados particionáveis

c. Realiza a quebra transacional

- Segundo os conjuntos de dados particionáveis identificados, particiona a transação;

- Cria subtransações na base de transações tentativas central;

- Modifica a transação origem para vincular as quebras.

Tabela 6-Pseudo-algoritmo de quebra transacional do quebrador de transações.

Os detalhes dos parâmetros e estruturas de dados envolvidos com a quebra podem ser obtidos no item 3.3.2, no tópico referente aos parâmetros da base de configuração utilizados pelo quebrador de transações.

Para perfis transacionais diferentes de aplicações cadastrais, o pseudo-algoritmo acima deve ser revisto de forma a contemplar de modo mais eficiente o comportamento transacional adotado.

$\mathrm{Na}$ seção 4 abordaremos mais detalhadamente um exemplo de aplicação do modelo transacional que realiza o processo de quebra transacional de transações baseado no perfil transacional de aplicação cadastral. 


\subsubsection{Pré-escalonador (seriador)}

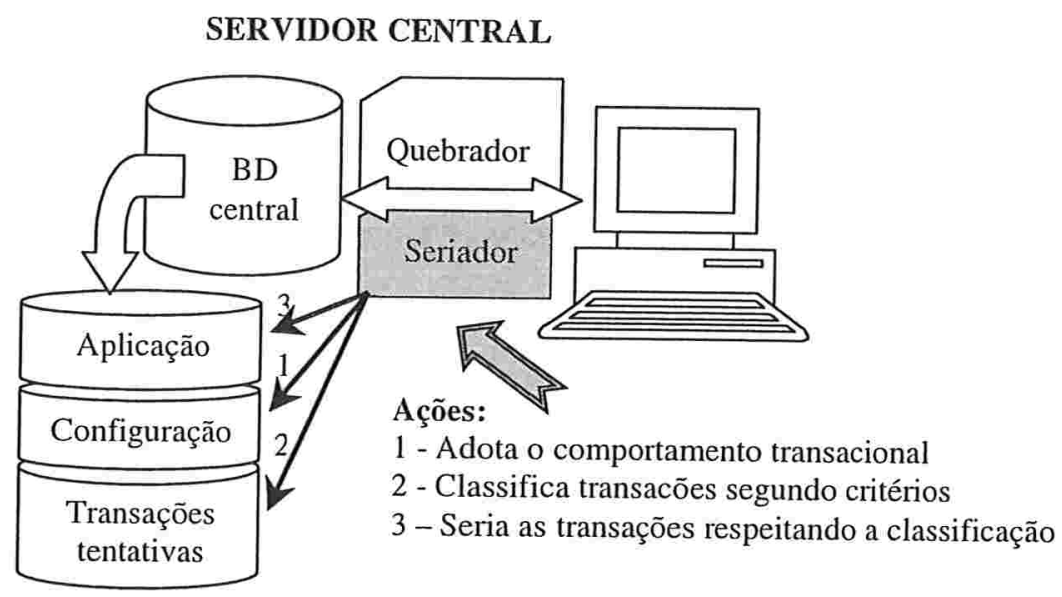

Figura 7 - Pré-escalonador localizado no servidor central.

Descreveremos agora outro importante componente do modelo transacional, o pré-escalonador (seriador) de transações assíncronas. Esse componente tem dois importantes papéis:

- Classificar as transações submetidas pelos clientes utilizando para isso as regras de domínio de aplicação adotadas pela corporação e representadas na base de dados de configuração.

- Seriar as transações da base de transações tentativas central, seguindo a ordenação obtida pelo processo de classificação.

O pré-escalonador utiliza a base de dados de configuração, que representa o perfil transacional instanciado pela corporação para reorganizar as transações clientes. A reclassificação de transações usa as regras vigentes na base de dados de configuração. Mudanças na representação das regras do perfil transacional adotado resultam em reconfigurações da base de dados de configuração. Assim, momentos distintos de processamento do pré-escalonador podem produzir diferentes classificações das transações.

Assumimos então que as transações clientes encontram-se organizadas e representadas na base de dados de transações tentativas do nó cliente. Assim que existir conexão com o servidor central, tais transações serão transmitidas ao servidor central para aceitação, permanecendo também na base cliente com o estado de transação tentativa (pendente e aguardando validação). As transações originadas nos vários nós clientes são registradas na base de transações tentativas central para serem classificadas e posteriormente seriadas (aceitas, parcialmente aceitas ou rejeitadas).

A classificação dessas transações está condicionada à periodicidade com que o pré-escalonador é processado. Um sistema que apresenta alta disponibilidade de conexão pode utilizar o pré-escalonador como um processo ativo que checa repetidamente a base de dados de transações tentativas central, considerando todas as transações existentes inclusive as recém-chegadas e as que nunca foram alvo de classificação anteriormente. 
Uma solução desconectada classifica as solicitações após intervalos de tempo, considerando todo o lote de transações existente no instante de sua execução. Uma diferença entre os dois modos de processamento reflete-se na quantidade de conflitos existente junto às várias transações e na ordem de aceitação.

No processo conectado, os pedidos são classificados e seriados quase imediatamente após o envio da transação ao servidor. Como conseqüência, uma resposta da análise confirmando ou rejeitando a transação estará disponível ao nó cliente quase que imediatamente após sua transmissão.

No processamento desconectado, os nós clientes submetem para aceitação lotes das transações realizadas desde a última conexão ao sistema. A ocorrência de conflitos no processamento desconectado é inevitável por causa da maior disponibilidade de acesso aos dados (uso quando desconectado do sistema).

A ordem de aceitação das transações também é influenciada pelas diferentes formas de processamento. O processamento desconectado analisa uma maior quantidade de transações, desde as recém-realizadas até as posteriormente solicitadas à última execução do pré-escalonador. Assim, em razão da reclassificação realizada pelo pré-escalonador, uma transação que antes seria atendida imediatamente na situação de processamento conectado, poderá ser colocada em segundo plano quando estiver no processamento desconectado.

Como a ocorrência de conflitos entre as transações desconectadas é mais numerosa, o pré-escalonador considera as regras de domínio de aplicação vigentes no modelo transacional instanciado para classificar as transações mais importantes conforme os interesses da organização. Esse tipo de seriação difere dos atuais modelos existentes no mercado [17] pois ressalta o foco de ação da empresa (usuário) segundo suas regras de negócio (necessidades). Esse modelo traz algumas vantagens pois pode ser facilmente reconfigurado e adaptado de forma a considerar as novas regras do modelo transacional instanciado.

O pré-escalonador é um componente da solução proposta, parametrizado pela base de dados de configuração através do perfil transacional adotado pela empresa. Para que esse perfil seja facilmente reconfigurado, o componente proposto deverá apresentar meios para uma rápida reorganização das regras utilizadas. A princípio imaginamos que o modo mais intuitivo de realizar essa configuração é por meio da escolha do uso ou não de determinada regra como critério a ser usado na validação das transações. Assim, determinado critério poderá ser desconsiderado facilmente pelo préescalonador, bastando apenas não ser selecionado para uso. As demais regras existentes continuariam válidas sendo aplicadas pelo pré-escalonador em seu processamento.

Dentre o conjunto de regras selecionadas, o pré-escalonador permite a escolha de uma ordem de precedência no uso das regras como critérios de classificação. Assim, o uso de regras no processamento do pré-escalonador, utilizando ordens invertidas, pode resultar em conjuntos distintos de classificação de transações, tanto pela ordem aplicada como pelo conteúdo selecionado.

Uma forma de implementar precedência entre regras é realizar a ordenação das 
mesmas na validação das transações pelo pré-escalonador. Garantimos com essa ordenação a aplicação das regras segundo os interesses da organização.

Outro nível adicional de funcionalidade e flexibilidade que o pré-escalonador proporciona é a associação de filtros às regras de domínio de aplicação existentes. Dependendo do perfil transacional instanciado, diferentes regras de negócio são utilizadas para configurar o pré-escalonador de transações (via base de configuração). Cada regra permite a associação de filtros de busca específicos que restringem a classificação e a seriação conforme os critérios relacionados aos interesses da corporação.

Os filtros respeitam as validações e restrições relacionadas às regras de negócio pois o comportamento transacional do domínio de aplicação representado na base de dados de configuração é obtido por meio de análise das regras da base de dados da aplicação.

A identificação dos filtros pode ser feita pela análise do tipo do dado ou do conjunto de valores válidos nos campos da base de dados da aplicação de onde as regras se originaram. Assim, essa análise mapeia o tipo de filtro necessário segundo a regra de negócio associada. Por exemplo, se o campo que originou a regra utiliza valores inteiros ou somente aceita um conjunto de valores predefinidos, então o filtro associado deve utilizar um valor de dado compatível e válido com as restrições existentes.

Além das restrições e validações associadas às regras de negócio, o uso de filtros exige a presença de operadores lógicos para realizar as operações de comparação e seleção das transações desejadas. São exemplos de operadores lógicos: igual, diferente, menor, maior, menor ou igual, maior ou igual, presente e não presente, representados, respectivamente, pelos símbolos $=,<>,\langle\rangle,,<=,\rangle=$, in e not in.

Esses operadores assemelham-se muito aos existentes no âmbito de banco de dados. Como exemplo temos as cláusulas in e $<$ do comando select do SQL (Linguagem de Consulta Estruturada). O mapeamento desses operadores lógicos de filtros nos comandos SQL visa minimizar as dificuldades existentes na implementação do componente de seriação presente no uso de sistemas gerenciadores de banco de dados (SGBD).

O poder do pré-escalonador associado ao uso de filtros e regras de negócio permite às aplicações o controle e seleção de solicitações conforme os interesses da corporação. Uma vez classificadas as transações, o sistema as atenderá fazendo a seriação segundo a ordenação obtida. A seriação reflete na base de dados da aplicação as modificações realizadas pelas transações clientes aceitas.

A base de dados de transações tentativas localizada no servidor central também é atualizada de forma a refletir as transações aceitas. Posteriormente, essas modificações deverão ser transmitidas às bases de transações tentativas clientes para que estes tomem conhecimento do andamento de suas transações.

Os detalhes relacionados ao processo de propagação das transações seriadas não serão tratados aqui pois este trabalho está focado na integração assíncrona de bases de dados autônomas. Para todos os efeitos, consideraremos que, após a 
seriação, existe a comunicação do servidor central com os nós clientes para repasse dos resultados do processo de aceite das transações.

O pré-escalonador é um dos componentes-chave do modelo transacional proposto pois utiliza na classificação e seriação de transações:

- Comportamento das regras de negócio representadas no perfil transacional;

- Associação do comportamento com os filtros de seleção;

- Ordenação e/ou uso dos critérios de seleção.

Todos esses conceitos acima apresentados são convertidos em estruturas de dados da base de configuração para representar o comportamento transacional do perfil transacional adotado. As regras representadas nessas estruturas são exemplos de parâmetros relacionados ao cálculo da prioridade de transação, que é o principal conceito utilizado pelo pré-escalonador para realizar a classificação das transações.

A seguir apresentamos um pseudo-algoritmo que ilustra os processos de classificação e seriação de transações realizados pelo pré-escalonador.

\section{Pseudo-algoritmo de classificação de transações}

1) Adota o comportamento transacional

a. Seleciona critérios da base de configuração;

$b$. Ordena critérios segundo regras de negócio;

c. Aplica filtros de seleção nos critérios.

2) Para cada transação da base central de transações tentativas

a. Calcula a prioridade da transação baseando-se nos fatores de relevância e no índice de ponderação dos fatores;

b. Registra na estrutura auxiliar o identificador da transação e sua prioridade.

3) Classifica as transações conforme as prioridades das transações.

Tabela 7 - Pseudo-algoritmo de classificação do pré-escalonador.

\section{Pseudo-algoritmo de seriação de transações}

1) Ordena as transações segundo a classificação obtida pela prioridade das transações.

2) Para cada transação deve-se verificar a existência de conflitos:

a. Se existe conflito, decide entre:

- Aceita uma transação e abortar as demais; ou

- Aceita as transações conflitantes conforme a ordem de classificação aplicando aceites totais e parciais.

b. Senão, aceita a transação.

3) Transações aceitas devem propagar as atualizações para a base da aplicação central.

\section{Tabela 8-Pseudo-algoritmo de seriação do pré-escalonador.}

Os detalhes dos parâmetros e estruturas de dados envolvidos com a classificação 
e seriação de transações podem ser obtidos no item 3.3.2, no tópico referente aos parâmetros da base de configuração utilizados pelo pré-escalonador.

A seriação realizada após a classificação garante à organização que o comportamento transacional adotado foi respeitado por meio dos parâmetros de seriação entre as solicitações conflitantes.

Após a seriação, as transações partidas são executadas e o conceito de grau de aceite permite que, após o processo de execução, tais transações partidas sejam avaliadas quanto ao critério de finalização. É importante observar que o conceito de término de uma transação está condicionado aos parâmetros de aceite. Podemos afirmar que uma transação $T$ foi finalizada sem que suas respectivas subtransações não sejam todas completadas.

Mais detalhes da estrutura do pré-escalonador podem ser obtidas na seção 4, entitulada "Exemplo de aplicação do modelo transacional", no item referente ao préescalonador. 


\section{Exemplo de aplicação do modelo transacional}

Após apresentarmos a implementação do modelo transacional conceitual na seção anterior, detalharemos agora um exemplo de aplicação cadastral com validação de dados que se beneficiou do modelo transacional ora proposto.

Essa seção encontra-se dividida em itens que correspondem aos vários componentes necessários à aplicação do modelo transacional conceitual. São eles: base de transações tentativas, base de configuração, quebrador de transações e préescalonador (seriador).

Antes de iniciarmos a descrição propriamente dita dos componentes do modelo transacional utilizado, faremos a seguir uma breve introdução a respeito da aplicação cadastral a ser abordada nesta seção.

\subsection{Aplicação: DECA (DEclaração CAdastral)}

Este item descreve a aplicação cadastral que serve de exemplo de utilização do modelo transacional.

O sistema cadastral denominado DECA Eletrônica constitui a aplicação cadastral da Secretaria de Estado dos Negócios da Fazenda do Estado de São Paulo (Sefaz-SP) responsável pelo cadastro dos contribuintes paulistas do ICMS (Imposto sobre Circulação de Mercadorias e Serviços). Para a realização cadastral, várias bases de dados estão envolvidas, tais como: cadastro contribuinte Jucesp, Receita Federal, Cetesb eic. Esta situação caracteriza um ambiente de multibases de dados.

Em 1995 iniciou-se na Sefaz-SP o Projeto de Modernização da Coordenadoria de Administração Tributária (Promocat) que visava à modernização dos processos e serviços ligados à administração tributária, tendo iniciado em 1998 sua fase mais executiva com o Posto Fiscal Eletrônico (PFE).

O PFE disponibilizava inicialmente apenas informações legislativas e de caráter geral, além de poucos serviços eletrônicos. Desejava-se abranger os serviços que mais demandavam tempo de atendimento aos contribuintes. A DECA apresentava um dos maiores índices de demanda de pessoas e tempo de serviço da Sefaz-SP, algo em torno de $40 \%$ a $50 \%$ do tempo total.

Mas como modernizar e automatizar um serviço tão complexo e interativo de modo a otimizar índices de demanda de tempo tão representativos como estes? Diversas foram as dificuldades encontradas pelas equipes de negócio e técnica, mas o modelo de negócio que mais se ajustou às necessidades existentes foi o modelo transacional.

A operação de "Abertura Inicial" no sistema DECA é o instrumento pelo qual um contribuinte do ICMS ingressa na Sefaz-SP. As opções de "Alteração" representam as diferentes maneiras existentes de manutenção cadastral.

Visando a facilitar a visualização da solução desenvolvida, apresentaremos a seguir exemplos da aplicação do modelo transacional por meio da implementação de seus diversos componentes. 
Maiores esclarecimentos quanto a dúvidas relacionadas aos termos de negócio apresentados nesse exemplo de aplicação e referentes ao sistema cadastral DECA Eletrônica podem ser encontrados no glossário localizado no apêndice 1, ao final da dissertação.

\subsection{Base de transações tentativas}

No sistema DECA Eletrônica a base de dados de transações tentativas recepciona todas as solicitações de modificação cadastral realizadas sobre os dados cadastrais das empresas inscritas no cadastro do ICMS, denominadas contribuintes.

As transações permanecem nessa base de dados até que sejam consistidos os dados modificados. As informações apenas são repassadas à base de dados da aplicação após as transações serem validadas pelo sistema e depois de obterem um grau de consistência mínima exigido pela Sefaz-SP.

A base de dados de transações tentativas está envolvida com diversas etapas do processo de sincronização de transações assíncronas. Relaciona-se inicialmente a etapa de recepção das transações clientes.

Em um segundo momento sofre os efeitos das quebras transacionais realizadas pelo componente quebrador de transações. As transações particionadas são armazenadas em sua estrutura junto com a referência da transação que as originou.

Posteriormente a base de transações tentativas é analisada pelo pré-escalonador que reclassifica as transações nela armazenadas considerando as regras de negócio adotadas. Baseado nessa reclassificação as transações são sincronizadas conforme o processo de seriação.

A estrutura da base de transações tentativas depende exclusivamente do perfil transacional adotado junto ao modelo transacional. Um subconjunto dos campos existentes em sua estrutura faz parte dos chamados campos de controle, que são necessários para viabilizar os processos de quebra transacional e seriação de transações.

Considerando a DECA Eletrônica e seu perfil transacional de sistema cadastral, identificamos a seguir um conjunto de campos de controle necessários à estrutura da base de transações tentativas. São eles: identificador do tipo da transação, identificador do tipo de operação ou serviço, controlador de consistência cadastral, mapeamento das informações que foram alvo das transações etc.

Para auxiliar o preenchimento desses campos de controle existem tabelas auxiliares que contêm valores predefinidos pelo perfil transacional e pelas regras de negócio adotadas. Esses valores limitam o universo de informações disponíveis e denotam um significado especial a cada valor do campo de controle.

As tabelas auxiliares e os campos de controle serão apresentadas no item referente ao quebrador de transações. No momento, apenas é relevante sabermos da existência desses campos e estruturas, e sua função no processo de consistências cadastrais. 
Quanto às informações cadastrais propriamente ditas, a base de dados de transações tentativas apresenta uma estrutura com pouca normalização [17]. O interesse em organizar as tabelas dessa forma é tornar os dados mais facilmente acessíveis nas várias etapas de consistência e validação cadastral.

O fator que mais influenciou na decisão da estrutura das tabelas com pouca normalização foi a eficiência no acesso aos dados. Dependendo da transação, um grande grupo de informações deve ser acessado conjuntamente. Dessa maneira, joins [17] são evitados no acesso aos dados armazenados.

Duas tabelas destacam-se como as principais estruturas de armazenamento das solicitações cadastrais: a tabela contrib_pri e socio_pri (vide apêndice 3).

A tabela contrib_pri armazena os dados referentes às informações cadastrais das empresas. Identificamos os seguintes conjuntos de dados que são armazenados em sua estrutura: razão social, nome fantasia, regime de apuração, tipo jurídico, CNAE-fiscal, endereço do estabelecimento, comunicação e contabilista.

Já a tabela socio_pri armazena os dados referentes às informações cadastrais dos sócios das empresas. Os conjuntos de dados envolvidos em sua estrutura são: quadro societário e endereço do quadro societário.

Mais detalhes sobre os conjuntos de dados cadastrais serão apresentados no item 4.3 referente ao mapeamento da quebra transacional.

Os campos das tabelas apresentam, em sua maioria, a opção de campos nulos. Os poucos campos que obrigatoriamente não devem ser nulos são os campos de
controle.

A justificativa pela quantidade de campos nulos é que as tabelas desnormalizadas recebem informações de vários tipos de transações. As transações de abertura de empresa contêm praticamente todos os campos da estrutura das tabelas.

Já as transações de alteração de dados podem ser compostas de subconjuntos de dados. Dessa forma, apenas um subconjunto de informações é alvo da transação, e a base de dados deve recepcionar tais dados. Os demais dados que não sofreram modificações permanecem nulos nas tabelas.

Detalhes a respeito dos tipos de transações existentes serão apresentados também no item 4.3 referente ao mapeamento da quebra transacional.

No modelo proposto temos a existência de instâncias da base de transações tentativas no lado servidor e cliente. Já o sistema DECA Eletrônica utiliza apenas a versão servidora dessa base de dados. Uma justificativa é o fato que o sistema DECA Eletrônica utiliza a arquitetura web.

Dessa maneira, todas as solicitações de modificação cadastral são encaminhadas à base de dados de transações tentativas no lado servidor, e no momento da recepção é gerado um protocolo para acompanhamento da transação, denominado protocolo DECA. 
Pelo protocolo DECA é possível que os usuários do sistema acompanhem todas as validações e consistências realizadas sobre os dados cadastrais das solicitações.

Para isso foi criada uma estrutura na base de dados de transações tentativas denominada tabela logcontrib_pri (vide apêndice 3), que registra as diversas etapas envolvendo as consistências dos protocolos DECA. Essa tabela também é controlada por outras tabelas auxiliares que predefinem os valores utilizados. Mais detalhes de seu uso no item 4.5 referente ao pré-escalonador (seriador).

Acreditamos que o uso da base de dados de transações tentativas clientes junto ao servidor central não inviabiliza o modelo proposto. Essa variante é a correta adaptação à arquitetura web do modelo transacional proposto. Em arquiteturas de computação móvel com protocolos de comunicação sem fio, é necessário o uso de instâncias nos lados servidor e cliente pois a indisponibilidade de comunicação entre as partes ocorre com muita freqüência.

Já no sistema DECA Eletrônica a Sefaz-SP optou pela arquitetura web como forma de comunicação entre os clientes e o fisco. Entendemos que na arquitetura web há uma simplificação do modelo transacional que proposto não inviabiliza sua apresentação como exemplo de implementação do modelo transacional.

Com tal simplificação do modelo transacional proposto não abordaremos nesse exemplo de aplicação o processo de sincronização entre as bases de dados tentativa servidora e clientes.

\subsection{Base de configuração}

Vimos anteriormente na seção de implementação do modelo transacional que dentre as várias funções da base de configuração, a principal é armazenar os parâmetros que representam o comportamento do modelo transacional instanciado. Esse comportamento do modelo transacional está relacionado às regras de negócio adotadas pela corporação.

Esse comportamento do modelo transacional no sistema DECA Eletrônica referese principalmente ao mapeamento dos perfis de usuário com os variados tipos de transações possíveis. Outra importante regra a ser representada é a quebra das transações e seu grau de importância para com as consistências cadastrais.

A base de dados de configuração é utilizada pelos componentes do modelo transacional proposto pois representa o comportamento transacional do perfil transacional adotado.

Seguindo os tópicos apresentados na seção 3.3.2, detalharemos a seguir a aplicação DECA Eletrônica.

\section{Parâmetros da base de configuração utilizados pelo quebrador de transações}

As estruturas a seguir apresentadas fazem parte da base de dados de configuração e são utilizadas como parâmetros pelo quebrador de transações no processo de quebra transacional. 


\section{Mapeamento da quebra transacional}

As interfaces web da DECA Eletrônica controlam o acesso do usuário às funcionalidades do sistema conforme o perfil do usuário. Cada funcionalidade implementada representa um tipo de operação / transação que deverá posteriormente ser validada e aceita.

O mapeamento de tais operações / transações no sistema obedece a uma hierarquia de classificação na qual podemos identificar como macrooperações com seus subtipos. A identificação dessas macrooperações considera as regras de negócio adotadas pela Sefaz-SP. São exemplos de macrooperações: Abertura, Alteração e Recadastramento.

Essas macrooperações apresentam subtipos que são classificados conforme as informações cadastrais envolvidas mais as regras de negócio adotadas. Por exemplo, na macrooperação Abertura temos dois subtipos de operações: Abertura inicial e Abertura por mudança de munícipio.

A seguir apresentamos o mapeamento das macrooperações e seus subtipos.

\begin{tabular}{|c|l|}
\hline Macrooperações & \multicolumn{1}{|c|}{ Subtipos } \\
\hline \multirow{5}{*}{ Abertura } & Inicial \\
& Inicial CNPJ isento \\
& Inicial NIRE isento \\
& Inicial NIRE/CNPJ isentos \\
& Mudança de município \\
& CNPJ cancelado \\
& Outro estado \\
\hline & Dados cadastrais \\
& Transferência estabelecimento \\
& DECA de ofício (uso até 2001) \\
& DECA corretiva (uso até 2001) \\
& Situação cadastral \\
& Cancelamento \\
& Suspensão \\
& Reativação de suspensão \\
& Restabelecimento eficácia \\
& DECA ofício contribuinte \\
& DECA ofício fiscal \\
& DECA corretiva contribuinte \\
& DECA corretiva fiscal \\
& Reativação de RES \\
\hline Recadastramento & Ação complementar \\
\hline
\end{tabular}

Tabela 9 - Macrooperações e seus subtipos na DECA Eletrônica.

O sistema DECA Eletrônica contempla as informações cadastrais que correspondem ao conjunto mínimo de dados exigidos pela Sefaz-SP para controle e identificação dos contribuintes. Em regra, toda e qualquer informação modificada que faça parte desse conjunto deve ser comunicada ao fisco pela DECA Eletrônica. 
No conjunto de dados exigido pela Sefaz-SP destacam-se: Nome/Razão social, Nome fantasia, CNPJ, Inscrição estadual, Comunicação, Contabilista responsável, Endereço do estabelecimento, Quadro societário etc. A equipe técnica baseou-se nas regras de negócio vigentes e nas várias consistências cadastrais realizadas com entidades externas e internas para definir diversos agrupamentos de informações. Esses agrupamentos reúnem dados comuns que tratam a respeito de uma mesma informação cadastral. Nosso interesse em juntar as informações em agrupamentos é definir os conjuntos de dados particionáveis, conforme definido em 3.3.2 no tópico referente ao mapeamento da quebra transacional.

Para ilustrar o conceito de agrupamento de dados considere o seguinte exemplo. O agrupamento Endereço do estabelecimento reúne todas as informações cadastrais relacionadas ao endereço do contribuinte. Fazem parte desse agrupamento os dados: Tipo de logradouro, Logradouro, Número, Complemento, Bairro, CEP, Município e UF.

Se considerarmos os dados acima destacados podemos identificar mais um motivo para agrupá-los em informações. Baseado nas regras de negócio vigentes, identificamos na DECA agrupamentos de informações por meio de dados que compartilham do mesmo tipo de acesso por parte das operações e usuários. Como exemplo temos as operações e os usuários que utilizam / acessam o dado Logradouro e também utilizam / acessam todos os demais dados que compõem a informação agrupada Endereço do estabelecimento.

Assim, podemos mais facilmente realizar o controle às informações cadastrais através de agrupamentos que reúnam características comuns dos dados do que por meio de tratamentos individuais nos campos cadastrais.

A seguir apresentamos uma lista de agrupamentos e seus respectivos dados.

\begin{tabular}{|c|c|}
\hline Agrupamentos & Dados \\
\hline Razão social & Nome / Razão social \\
\hline Nome fantasia & Nome fantasia \\
\hline CNPJ & CNPJ \\
\hline Capital social & Capital social \\
\hline Tipo de estabelecimento & $\begin{array}{l}\text { Tipo de estabelecimento } \\
\text { CNPJ do franquiador }\end{array}$ \\
\hline Regime de apuração & \begin{tabular}{|l|} 
Regime de apuração \\
Substituição tributária \\
Data de início \\
\end{tabular} \\
\hline CNAE-fiscal & $\begin{array}{l}\text { CNAE-fiscal } \\
\text { Data de início }\end{array}$ \\
\hline Endereço do estabelecimento & $\begin{array}{l}\text { Tipo de logradouro } \\
\text { Logradouro } \\
\text { Número } \\
\text { Complemento } \\
\text { Bairro } \\
\text { CEP } \\
\text { Município } \\
\text { UF }\end{array}$ \\
\hline
\end{tabular}




\begin{tabular}{|c|l|}
\hline Comunicação & Fone \\
& FAX \\
& E-mail \\
\hline \multirow{3}{*}{ Contabilista } & Tipo de contabilista \\
& CRC \\
& CPF / CNPJ \\
\hline \multirow{3}{*}{ Quadro societário } & Tipo de participação \\
& Assina pelo estabelecimento \\
& CPF/CNPJ \\
& RG \\
\hline \multirow{5}{*}{ Endereço do quadro societário } & Tipo de logradouro \\
& Logradouro \\
& Número \\
& Complemento \\
& Bairro \\
& CEP \\
& Município \\
& UF \\
\hline Tipo jurídico & Tipo jurídico \\
\hline
\end{tabular}

Tabela 10 - Agrupamentos de dados da DECA Eletrônica.

A tabela acima é uma referência à tabela 1 apresentada em 3.3.2, que mapeia os conjuntos de dados particionáveis.

O sistema DECA utiliza os agrupamentos de dados como ponto de referência para a quebra das transações cadastrais. Dependendo do tipo de operação realizada a transação origem é particionada em várias outras subtransações sendo que cada subtransação é constituída apenas de um agrupamento específico de dados.

Assim podemos delimitar a granularidade da quebra transacional realizando o mapeamento dos agrupamentos de dados modificados. A tabela acima apresenta uma visão das possíveis formas de particionamento de uma transação. Utilizamos os agrupamentos de dados para identificar os grupos de informações que foram alvo de uma operação.

A granularidade da quebra transacional pode ser reconfigurada por meio da união de agrupamentos de dados. Uma possível reconfiguração seria criar um novo agrupamento, por exemplo Nome, que reúne as informações dos agrupamentos Nome/Razão social e Nome fantasia. A decisão de quais agrupamentos / dados devem ser reunidos depende exclusivamente das regras de negócio adotadas pela corporação.

Por decisão da equipe de negócios as operações de abertura podem sofrer quebra transacional mas apenas serão aceitas se todas as subtransações geradas também forem aceitas. Essa premissa é pré-requisito para que o contribuinte tenha seu cadastro inicial aceito pela Sefaz-SP.

Deseja-se com tal regra que as operações de abertura mantenham sua atomicidade transacional, sendo sua validade condicionada à aceitação de todas as informações prestadas. 
A operação de abertura utiliza essa regra pois são realizadas diversas consistências e validações cadastrais que podem envolver desde complexos cruzamentos de informações com entidades externas, como também visitas fiscais ao estabelecimento para comprovação das informações.

Somente após as informações cadastrais serem aceitas é que ocorre a geração da Inscrição Estadual (IE), número de identificação cadastral dos contribuintes paulistas do ICMS.

Já as operações de alteração e recadastramento beneficiam-se completamente da quebra transacional pois podem ser aceitas mesmo que parcialmente. Dessa maneira, a granularidade dessas transações pode ser diminuída com o intuito de facilitar a aceitação das informações prestadas.

Com a quebra transacional cada subtransação pode ser validada separadamente por meio de análise nos dados do agrupamento que esta representa. Para compreender como a quebra transacional auxilia na aceitação de informações cadastrais na Sefaz-SP, observe o exemplo a seguir:

Operação: Alteração de dados cadastrais (transação T)

Dados envolvidos: Nome/Razão social, CNAE-fiscal e Comunicação

Inconsistências existentes: Código do CNAE-Fiscal Inválido

$1^{\circ}$ caso: Sem quebra transacional

A transação $T$ não pode ser aceita pois existe inconsistência cadastral relacionada ao código do CNAE-fiscal. As informações inconsistentes devem ser corrigidas para que a transação seja aceita. Caso contrário, a transação será negada.

Nesse caso as informações cadastrais de Nome/Razão social e comunicação não podem ser aceitas pois fazem parte da mesma transação.

$2^{\circ}$ caso: Com quebra transacional

A transação $T$ de alteração cadastral pode ser dividida em 3 subtransações conforme os agrupamentos dos dados envolvidos.

$T_{1}=$ Transação do agrupamento Nome/Razão social

$\mathrm{T}_{2}=$ Transação do agrupamento CNAE-fiscal

$\mathrm{T}_{3}=$ Transação do agrupamento Comunicação

A inconsistência cadastral relacionada à transação $T_{2}$ não impede que as demais transações $T_{1}$ e $T_{3}$ sejam aceitas.

Como conseqüência da parcialidade na aceitação de transações obtemos uma significativa redução na quantidade de conflitos existentes entre transações conflitantes. 
Vale ressaltar que o uso da quebra transacional depende da correta identificação das informações cadastrais que são mutuamente exclusivas. $O$ intuito de criar os agrupamentos de dados é reunir as informações que são interdependentes visando à posterior quebra transacional.

Tabela 11 - Exemplo de quebra transacional.

Mais detalhes a respeito do processo de quebra transacional podem ser obtidos na descrição do componente quebrador de transações, no item 4.4.

\section{Tipos de transações particionadas}

O sistema DECA Eletrônica utiliza o conceito de quebra transacional e parcialidade de aceitação com o intuito de reduzir a quantidade de conflitos entre as transações que utilizam o modelo de sincronização assíncrono. Baseado nessas características, apresentamos dois tipos de transação identificados pelo modelo transacional proposto: transação substituta e transação condicionada.

As operações de abertura necessitam da atomicidade transacional na operação para serem aceitas no sistema. Utilizaremos as transações de alteração e recadastramento para exemplificar os tipos de transações particionadas.

Transação substituta: As transações substitutas correspondem às diversas subtransações geradas a partir da quebra transacional e tratam individualmente cada agrupamento de dados. As operações de alteração são particionadas nas subtransações correspondentes aos agrupamentos de dados envolvidos, e se uma subtransação for validada, esta pode ser seriada individualmente na base de dados da aplicação independente das demais.

Essa prática só é possível por causa do isolamento existente entre os agrupamentos de dados. Se um dado for dependente de outros, este deve estar representado junto com os demais em algum agrupamento.

Como mencionado anteriormente no modelo transacional, a transação substituta não necessita ser confirmada pelo cliente para ter seu particionamento aceito. Tal opção fica a encargo da transação condicionada.

Transação condicionada: São transações que necessitam do aceite do cliente para terem seu particionamento validado. Ủma vez confirmadas, o particionamento ocorre, e as subtransações podem ser seriadas independentemente das demais subtransações existentes.

Nas transações condicionais existe o conceito de porcentagem condicional que controla o limite mínimo que uma transação deve atender para que não necessite da confirmação do cliente. Assim, se uma subtransação obtiver aceitação superior à porcentagem condicional, a quebra transacional ocorre e sua seriação já pode ser realizada diretamente. 


\section{Parâmetros da base de configuração utilizados pelo pré-escalonador (fase de classificação)}

Detalharemos agora as estruturas da base de configuração utilizadas pelo préescalonador na etapa de classificação de transações. Ressaltamos que esse processo de classificação ocorre nas transações armazenadas na versão servidora da base de transações tentativas. Neste momento, o processo de quebra transacional já foi realizado e as transações que podem ser alvo do processo de classificação são as subtransações geradas pela quebra transacional mais as transações clientes que, por algum motivo, não sofreram partições pelo quebrador de transações.

\section{Origem e destino de transações}

Entendemos como informações relevantes neste tópico a identificação dos perfis de usuários que originam as transações. Identificamos no sistema DECA três principais perfis de usuários: fiscal, contribuinte e contabilista.

O perfil fiscal representa os usuários internos da Sefaz-SP que são responsáveis por homologar as modificações cadastrais. Seu número é da ordem de cinco mil pessoas. Já o perfil contabilista representa a classe de contadores que são responsáveis pela contabilidade dos contribuintes e seu número estimado é de duzentos mil usuários. $E$, por fim, o perfil contribuinte, que representa as empresas que estão inscritas no cadastro DECA e que acessam este sistema eletrônico com o intuito de notificar modificações cadastrais. A quantidade de contribuintes que utiliza o PFE é de aproximadamente novecentas mil empresas.

\begin{tabular}{|l|l|}
\hline Perfis de usuários & Quantidade \\
\hline Fiscais & 5000 \\
\hline Contabilistas & 200000 \\
\hline Contribuintes & 900000 \\
\hline
\end{tabular}

Tabela 12 - Perfis de usuários da DECA Eletrônica.

Todas as operações de manutenção cadastral realizadas no sistema DECA são encaminhadas à base de dados de transações tentativas para que sejam posteriormente validadas. Uma vez validadas as transações, os dados que foram alvo de modificação são atualizados na base de dados da aplicação.

Baseado nos perfis de usuários do sistema DECA Eletrônica, identificamos a seguir o fator de relevância conforme as origens e destinos das transações. O conceito de fator de relevância é utilizado para o cálculo da prioridade das transações.

\begin{tabular}{|l|l|}
\hline Perfis de usuários & Fator de relevância \\
\hline Fiscal & Alto \\
\hline Contabilista & Médio \\
\hline Contribuinte & Médio \\
\hline
\end{tabular}

Tabela 13 - Representação do fator de relevância baseado nos perfis de usuários.

A tabela acima é uma referência à tabela 3 apresentada em 3.3.2, que mapeia o fator de relevância baseado no conceito de origem e destino das transações. 


\section{Pesos transacionais}

Os pesos transacionais estão relacionados com o conceito da quebra transacional. Dependendo das regras de negócio vigentes, uma organização pode valorizar mais certas subtransações geradas por causa do conteúdo das informações manipuladas.

Diversos fatores podem influenciar na composição dos pesos transacionais, tais como: usuário que gerou a solicitação, tipo da transação e conjunto de dados envolvidos nas operações.

O uso dos pesos transacionais no cálculo da porcentagem de aceite é uma maneira vislumbrada para permitir que as mudanças nas regras de negócio adotadas reflitam mais rapidamente no processo de seriação de transações.

No sistema DECA Eletrônica os pesos transacionais são configurados conforme o tipo da operação realizada e o conjunto de dados envolvidos em uma transação. O intuito é refletir a relevância que um determinado dado tem em uma específica transação.

Um fator que também influencia nos pesos transacionais é o perfil do usuário que originou a transação. Podemos classificar o perfil dos usuários em fiscal e não-fiscal (perfil contribuinte e contabilista). Por decisão da equipe de negócios definiu-se que as operações dos fiscais não sofrem validações de dados. Tal decisão foi tomada pela compreensão de que uma operação realizada por um fiscal apresenta veracidade incontestável mesmo que sejam observadas certas inconsistências cadastrais nas etapas de cruzamentos de dados com entidades externas e internas.

Abaixo apresentamos uma tabela com o mapeamento dos pesos transacionais envolvidos com as operações e agrupamentos de dados no sistema DECA Eletrônica. Os pesos transacionais são denominados fatores de relevância para o cálculo da prioridade das transações.

\begin{tabular}{|c|c|c|}
\hline Operação & Agrupamentos de dados & Pesos transacionais \\
\hline Abertura & $\begin{array}{l}\text { Razão social } \\
\text { Nome fantasia } \\
\text { CNPJ } \\
\text { Capital social } \\
\text { Tipo de estabelecimento } \\
\text { Regime de apuração } \\
\text { CNAE-fiscal } \\
\text { Endereço do estabelecimento } \\
\text { Comunicação } \\
\text { Contabilista } \\
\text { Quadro societário } \\
\text { Endereço do quadro societário } \\
\text { Tipo jurídico }\end{array}$ & $\begin{array}{c}\text { Não são aplicados } \\
\text { pois deseja-se } \\
\text { atomicidade } \\
\text { transacional nas } \\
\text { operações de } \\
\text { abertura }\end{array}$ \\
\hline
\end{tabular}




\begin{tabular}{|c|l|l|} 
& Razão social & Médio \\
& Nome fantasia & Baixo \\
& CNPJ & Alto \\
& Capital Social & Baixo \\
& Tipo de estabelecimento & Baixo \\
Regime de apuração & Alto \\
& CNAE-fiscal & Alto \\
& Endereço do estabelecimento & Alto \\
& Comunicação & Baixo \\
& Contabilista & Médio \\
& Quadro societário & Médio \\
& Endereço do quadro societário & Baixo \\
& Tipo jurídico & Alto \\
\hline Razão social & Baixo \\
& Nome fantasia & Baixo \\
& CNPJ & Médio \\
& Capital social & Baixo \\
& Tipo de estabelecimento & Baixo \\
& Regime de apuração & Alto \\
CNAE-fiscal & Alto \\
Endereço do estabelecimento & Alto \\
& Comunicação & Baixo \\
& Contabilista & Médio \\
& Quadro societário & Baixo \\
Endereço do quadro societário & Baixo \\
Tipo jurídico & Alto \\
\hline
\end{tabular}

Tabela 14 - Mapeamento dos pesos transacionais no sistema DECA Eletrônica.

Para facilitar o cálculo da porcentagem de aceite, classificamos os pesos transacionais Baixo, Médio e Alto em valores numéricos 1, 2 e 3, respectivamente. Tais valores podem ser reconfigurados para ajustar a novas necessidades das regras de negócios. Essa característica é desejada pois traz dinamismo nas correções dos pesos conforme mudanças nas regras de negócio.

\begin{tabular}{|l|l|}
\hline Pesos transacionais & Valor \\
\hline Baixo & 1 \\
\hline Médio & 2 \\
\hline Alto & 3 \\
\hline
\end{tabular}

Tabela 15 - Classificação dos pesos transacionais.

Para facilitar o entendimento da relação entre os conceitos de peso transacional e porcentagem de aceite, acompanhe a seguir um exemplo no sistema DECA Eletrônica.

Uma dada transação $T$ de alteração cadastral pode ser dividida em 3 subtransações conforme os agrupamentos dos dados envolvidos. 
Quebras transacionais:

$t_{1}=$ Transação do agrupamento Nome/Razão social

$t_{2}=$ Transação do agrupamento CNAE-fiscal

$t_{3}=$ Transação do agrupamento Comunicação

Pesos transacionais relacionados aos agrupamentos de dados:

$p_{1}=$ Agrupamento Nome/Razão social $=$ Peso Médio

$p_{2}=$ Agrupamento CNAE-fiscal $=$ Peso Alto

$p_{3}=$ Agrupamento Comunicação $=$ Peso Baixo

Valores dos pesos transacionais conforme classificação:

$$
\begin{aligned}
& \text { Peso Baixo = } 1 \\
& \text { Peso Médio = } 2 \\
& \text { Peso Alto }=3
\end{aligned}
$$

Cálculo da soma dos pesos das subtransações de T:

Transação T é composta de $t_{1}, t_{2}$ e $t_{3}$

Conforme as transações particionadas $x$ agrupamentos de dados $x$ pesos transacionais, temos:

$$
\begin{aligned}
& t_{1}=p_{1}=\text { Peso Médio }=2 \\
& t_{2}=p_{2}=\text { Peso Alto }=3 \\
& t_{3}=p_{3}=\text { Peso Baixo }=1
\end{aligned}
$$

Assim, a soma dos pesos das subtransações de $T$ é:

$$
\text { soma_dos_pesos }\left[p_{1} . . p_{3}\right]=p_{1}+p_{2}+p_{3}=2+3+1=6
$$

Considere a seguinte situação envolvendo as subtransações de T:

Subtransações t1 e t3 aceitas e t2 negada.

Para efeito de cálculo, $t_{x}$ aceita $=1$ e $t_{x}$ negada $=0$, onde $x=1 . . n$.

Fórmula do cálculo da porcentagem de aceite:

$$
\left(t_{1} \times p_{1}+\ldots+t_{n} \times p_{n}\right) / \text { soma_dos_pesos }\left[p_{1} . . p_{n}\right]
$$

Cálculo da porcentagem de aceite de $T$ :

$$
\begin{aligned}
& \left(t_{1} \times p_{1}+t_{2} \times p_{2}+t_{3} \times p_{3}\right) / \text { soma_dos_pesos }\left[p_{1} . . p_{n}\right] \\
= & ((1 \times 1)+(0 \times 3)+(1 \times 2)) / 6= \\
= & (1+0+2) / 6= \\
= & 3 / 6=0,50 \\
& \text { sendo a porcentagem de aceite de } T \text { igual a } 50 \%
\end{aligned}
$$

Tabela 16 - Exemplo do cálculo da porcentagem de aceite no sistema DECA Eletrônica.

O exemplo acima ilustra a forma de cálculo da porcentagem de aceite junto com os pesos transacionais. Cada transação particionada, segundo as regras de negócio adotadas, apresenta uma importância ou peso relacionado a sua aceitação. Uma informação cadastral é mais ou menos importante dependendo do nível de consistência exigido dela para que esta seja aceita no sistema.

Uma transação com peso transacional baixo não pode ser interpretada como sendo de pouca relevância para a organização, e sim que as consistências cadastrais 
exigidas por esta são pequenas e a pouca consistência cadastral não é empecilho para a negação da transação.

Transações que contemplam dados com alto peso transacional contêm informações cadastrais que necessitam ser fortemente consistidas, verificadas e analisadas pois causam grandes influências na declaração cadastral. Por exemplo, a informação regime de apuração é um dado com peso transacional alto no sistema DECA. O motivo que nos leva a classificá-la como tal é que uma alteração nesse dado pode significar a suspensão do recolhimento de impostos e diminuição da carga tributária incidente sobre o contribuinte do ICMS.

Conforme o exemplo anterior, mesmo que a maioria das subtransações seja aceita, a não-aceitação de uma subtransação que manipula dados relevantes para a organização resulta em uma baixa porcentagem de aceite da transação partida. A utilização de pesos transacionais é importante para ajustar a quebra de transações às necessidades representadas pelas regras de negócio adotadas pela organização segundo o perfil transacional instanciado.

\section{Prioridade das transações}

Segundo o modelo transacional conceitual apresentado em 3.2, a prioridade da transação é o principal conceito para o processo de classificação das transações armazenadas na base de transações tentativas central.

No sistema DECA Eletrônica o cálculo da prioridade da transação utiliza as informações da base de configuração para considerar o comportamento transacional adotado pela Sefaz-SP. Dentre as informações utilizadas no cálculo, destacam-se a origem das transações e os pesos transacionais.

O resultado do cálculo da prioridade da transação é armazenado em uma estrutura na base de transações tentativas central e será usado para ordenar as transações no processo de seriação. A adoção da classificação no processo de seriação garante à Sefaz-SP que o comportamento transacional foi respeitado.

\begin{tabular}{|c|c|}
\hline Protocolo DECA & Prioridade da transação \\
\hline chave primária & [Alta, Média, Baixa] \\
\hline
\end{tabular}

Tabela 17 - Tabela contendo o resultado do cálculo da prioridade da transação.

A tabela acima é uma referência à tabela 5 apresentada em 3.3.2, que representa a classificação das transações segundo a prioridade das transações.

\section{Parâmetros da base de configuração utilizados pelo pré-escalonador (fase de
seriação)}

Detalharemos agora as estruturas da base de configuração utilizadas pelo préescalonador na etapa de seriação de transações. Ressaltamos que tal processo ocorre nas transações armazenadas na versão servidora da base de transações tentativas e utiliza a ordenação obtida na fase de classificação das transações pelo pré-escalonador. 


\section{Porcentagem de aceite}

A porcentagem de aceite está relacionada ao conceito de quebra transacional e à parcialidade na aceitação de transações. Seu propósito é servir como métrica para mensurar a aceitação global de uma transação.

Baseado nas regras de negócio adotadas, certas transações podem ter uma porcentagem de aceite maior ou menor. São exemplos de regras que podem interferir na porcentagem: perfil do usuário que originou a transação, tipo de operação realizada e conjunto de dados envolvidos.

A porcentagem de aceite corresponde ao cálculo das execuções das transações $t_{i} s$ somados aos pesos $a_{k}$ s, divididas pelo somatório das $a_{k} s$ de todas as $t_{i} s$ geradas no processo de quebra transacional.

A atomicidade das subtransações no sistema DECA está associada aos agrupamentos de dados. Não é aceitável, para o sistema cadastral DECA, que num mesmo agrupamento de dados exista uma subtransação mais ou menos correta. A parcialidade existe entre os agrupamentos que compõem uma transação e não dentro dos mesmos.

Identificamos abaixo alguns pontos que influenciam nas porcentagens de aceite no sistema DECA Eletrônica.

\begin{tabular}{|c|l|l|}
\hline Operação & \multicolumn{1}{|c|}{ Dados } & \multicolumn{1}{|c|}{ Porcentagem de aceite } \\
\hline Abertura & Todos os agrupamentos & $\begin{array}{l}\text { Não aplicado, pois existe } \\
\text { atomicidade da operação }\end{array}$ \\
\hline Alteração & Agrupamentos diversos & $\begin{array}{l}\text { Corresponde ao número de } \\
\text { subtransações aceitas pelo } \\
\text { número total de } \\
\text { subtransações geradas }\end{array}$ \\
\hline Recadastramento & Agrupamentos diversos & $\begin{array}{l}\text { Corresponde ao número de } \\
\text { subtransações aceitas pelo } \\
\text { número total de } \\
\text { subtransações geradas d }\end{array}$ \\
\hline
\end{tabular}

Tabela 18 - Regras envolvendo a porcentagem de aceite na DECA Eletrônica.

\section{Grau de aceite}

Como dito anteriormente, o pré-escalonador classifica as transações clientes utilizando o comportamento transacional representado na base de dados de configuração, que armazena as regras de domínio de aplicação instanciadas pelo modelo transacional adotado. As transações são seriadas seguindo a ordem estabelecida pelo pré-escalonador.

O grau de aceite define a finalização das transações por meio da porcentagem de aceite. No sistema DECA Eletrônica o grau de aceite global está configurado para $60 \%$.

Dessa maneira, as transações que apresentarem porcentagem de aceite igual a 
$60 \%$ são consideradas como finalizadas pela aplicação pois atenderam ao limite mínimo de porcentagem de aceite definido pelo grau de aceite.

\subsection{Quebrador de transações}

O quebrador de transações realiza a quebra transacional das transações armazenadas na base de transações tentativas central segundo o comportamento parametrizado na base de configuração do modelo transacional instanciado.

Sua implementação no sistema DECA Eletrônica envolve o particionamento das transações de modificação cadastral conforme os agrupamentos de dados.

Antes de iniciarmos efetivamente a descrição do processo de quebra transacional é necessário identificar algumas estruturas auxiliares e campos de controle para viabilizar tal solução. Todas as estruturas e campos identificados abaixo fazem parte da estrutura da base de configuração conforme apresentados na seção 3.3.2.

Dentre as estruturas auxiliares e os campos de controle existentes no sistema DECA Eletrônica destacam-se:

\section{Identificador do tipo da transação}

Conforme apresentado anteriormente na descrição da base de configuração no subitem "Quebra transacional", o sistema DECA Eletrônica apresenta três principais tipos de transações: abertura, alteração e recadastramento.

A base de transações tentativas apresenta em sua estrutura um campo de controle denominado pa_acao que é responsável por identificar o tipo da transação de cada solicitação cadastral armazenada em sua estrutura. A seguir apresentamos a tabela auxiliar que armazena os valores predefinidos com os códigos do pa_acao.

\begin{tabular}{|l|c|}
\hline Tipos de transações & pa_acao \\
\hline Abertura & 1 \\
\hline Alteração & 2 \\
\hline Recadastramento & 3 \\
\hline
\end{tabular}

Tabela 19 - Campo de controle pa_acao.

\section{Identificador dos subtipos de transações}

Para cada tipo de transação apresentada acima existem subtipos de operações que foram criadas para representar os diferentes serviços eletrônicos oferecidos no sistema DECA.

A seguir apresentamos uma relação com os subtipos de transação em seu formato de tabela auxiliar com os valores de tp_servico predefinidos. 


\begin{tabular}{|c|l|l|}
\hline Transações & \multicolumn{1}{|c|}{ Subtipos } & tp_servico \\
\hline \multirow{5}{*}{ Abertura } & Inicial & 1000 \\
& Inicial CNPJ isento & 1001 \\
& Inicial NIRE isento & 1002 \\
& Inicial NIRE/CNPJ isentos & 1003 \\
& Mudança de município & 1004 \\
& CNPJ cancelado & 1005 \\
& Outro estado & 1100 \\
\hline \multirow{5}{*}{ Alteração } & Dados cadastrais & 2000 \\
& Transferência estabelecimento & 2001 \\
& DECA de ofício (uso até 2001) & 2002 \\
& DECA corretiva (uso até 2001) & 2003 \\
& Situação cadastral & 2004 \\
& Cancelamento & 2005 \\
& Suspensão & 2006 \\
& Reativação de suspensão & 2007 \\
& Restabelecimento eficácia & 2008 \\
& DECA ofício contribuinte & 2009 \\
& DECA ofício fiscal & 2010 \\
& DECA corretiva contribuinte & 2011 \\
& DECA corretiva fiscal & 2012 \\
& Reativação de RES & 2013 \\
\hline Recadastramento & Ação complementar & 4000 \\
\hline
\end{tabular}

Tabela 20 - Transações, subtipos e seu mapeamento em tp_servico da tabela contrib_pri.

\section{Mapeamento das informações alvo das transações}

Apresentamos anteriormente o mapeamento das informações cadastrais e seus respectivos agrupamentos de dados. Na oportunidade nos preocupamos apenas em relacionar as informações com os respectivos agrupamentos de dados.

O mapeamento das informações-alvo das transações ocorre por meio de uma estrutura de bits que encontra-se representada na base de dados de transações tentativas. Esse campo de controle tem um tamanho predefinido de trinta posições, porém o mapeamento atual não ocupa $50 \%$ de sua capacidade.

Dependendo da transação realizada, diferentes conjuntos de dados podem ser alvo de atualizações. Para cada agrupamento de dados que foi alvo de modificação cadastral o seu respectivo bit deve ser setado no campo de controle da base de transações tentativas. Denominamos esse campo de controle na tabela contrib_pri de bt_contrib.

A seguir apresentamos o mapeamento dos agrupamentos de dados com suas respectivas posições no bit de controle bt_contrib.

\begin{tabular}{|l|l|}
\hline \multicolumn{1}{|c|}{ Agrupamentos de dados } & Posição do bt_contrib \\
\hline Razão social & 1 \\
\hline Nome fantasia & 2 \\
\hline CNPJ & 3
\end{tabular}




\begin{tabular}{|l|l|}
\hline Capital social & 4 \\
\hline Tipo de estabelecimento & 5 \\
\hline Regime de apuração & 6 \\
\hline CNAE-fiscal & 7 \\
\hline Endereço do estabelecimento & 8 \\
\hline Comunicação & 9 \\
\hline Contabilista & 10 \\
\hline Quadro Societário & 11 \\
\hline Endereço do quadro societário & 12 \\
\hline Tipo jurídico & 13 \\
\hline
\end{tabular}

Tabela 21 - Mapeamentos dos agrupamentos de dados por meio de bits.

O exemplo abaixo auxilia na compreensão do mapeamento dos agrupamentos de dados com bits de controle.

Uma dada transação $T$ de alteração cadastral apresenta os seguintes agrupamentos de dados envolvidos em sua operação:

Agrupamentos de dados:

Agrupamento Nome/Razão social

Agrupamento CNAE-fiscal

Agrupamento Comunicação

Mapeamento de bits segundo agrupamentos de dados:

Agrupamento Nome/Razão social = bit 1

Agrupamento CNAE-fiscal $=$ bit 7

Agrupamento Comunicação = bit 9

Assim, o mapeamento de bits a ser gravado na base de transações tentativas no campo de controle bt_contrib é:

1000001010.0000000000.0000000000. A máscara de visualização: 1234567890.1234567890.1234567890 auxilia na observação da posição dos bits, onde os números representam as posições e o ponto separa os bits em grupos de 10.

Tabela 22 - Mapeamento de agrupamentos de dados com bits de controle bt_contrib.

As operações de abertura são um caso especial do mapeamento de bits. Nelas o bt_contrib é igual a 1111111111.1111111111 .1111111111 pois todos os dados devem ser informados para que o cadastro inicial seja realizado.

Uma extensão do mapeamento de bits de controle é o quadro societário. Comentamos anteriormente que além da tabela contrib_pri, a tabela socio_pri é uma das principais estruturas cadastrais das bases de transações tentativas do sistema DECA Eletrônica.

A tabela socio_pri armazena as informações referentes aos participantes do 
quadro societário das empresas. Os agrupamentos de dados Quadro societário e Endereço do quadro societário são representados através dos bits 11 e 12 do bt_contrib, porém as informações cadastrais dos mesmos encontram-se armazenadas na tabela socio_pri. Assim, somente existirão dados na tabela socio_pri se os bits 11 ou 12 do bt_contrib estiverem setados.

As estruturas da base de dados de transações tentativas não encontram-se totalmente desnormalizadas. Existe um relacionamento 1-N entre as tabelas contrib_pri e socio_pri pois vários sócios podem fazer parte do quadro societário de uma empresa.

A tabela socio_pri também apresenta em sua estrutura campos de controle semelhantes à tabela contrib_pri que são necessários para o mapeamento da operação realizada e dos dados modificados.

A seguir apresentamos o identificador do tipo de operação, também denominado tp_servico, da tabela socio_pri.

\begin{tabular}{|l|l|}
\hline \multicolumn{1}{|c|}{ Operação } & \multicolumn{1}{c|}{ tp_servico } \\
\hline Inclusão de sócio & 3000 \\
\hline Alteração de dados & 3001 \\
\hline Exclusão de sócio & 3002 \\
\hline Sem operação & 3003 \\
\hline
\end{tabular}

Tabela 23 - Operações e seu mapeamento em tp_servico da tabela socio_pri.

Semelhante aos bits do bt_contrib, temos na tabela socio_pri o bt_socio que representa em bits os dados cadastrais do quadro societário. Abaixo representamos o mapeamento dos dados cadastrais e suas posições na estrutura de bits de controle.

\begin{tabular}{|l|l|}
\hline \multicolumn{1}{|c|}{ Dados de Sócio } & Posição do bt_socio \\
\hline CPF & 1 \\
\hline Nome & 2 \\
\hline Endereço & 3 \\
\hline Tipo de participação & 4 \\
\hline Comunicação & 5 \\
\hline RG & 6 \\
\hline Assina pela empresa & 7 \\
\hline Data início da participação & 8 \\
\hline
\end{tabular}

Tabela 24 - Mapeamentos dos agrupamentos de dados de sócio por meio de bits do bt_socio.

Por meio da estrutura de bits o modelo transacional pode facilmente identificar os conjuntos de dados que foram alvo das solicitações de modificação cadastral.

Quando um determinado bit não encontra-se setado, então a base de transações tentativas não armazena as informações cadastrais referentes ao agrupamento de dados que o bit representa. Esse é o motivo pelo qual a base de transações tentativas tem em sua estrutura um grande número de campos que podem ser nulos.

O quebrador de transações utiliza todos os campos de controle existentes na base 
de transações tentativas para identificar o tipo e subtipo de operação realizada e os agrupamentos de dados envolvidos com as modificações solicitadas. Baseado nessas informações ocorre o processo de quebra transacional.

A seguir apresentamos um exemplo de como os componentes do modelo transacional identificam as operações e os dados-alvo de modificações. Esse exemplo ilustra parte do pseudo-algoritmo da quebra transacional apresentado em 3.3.3.

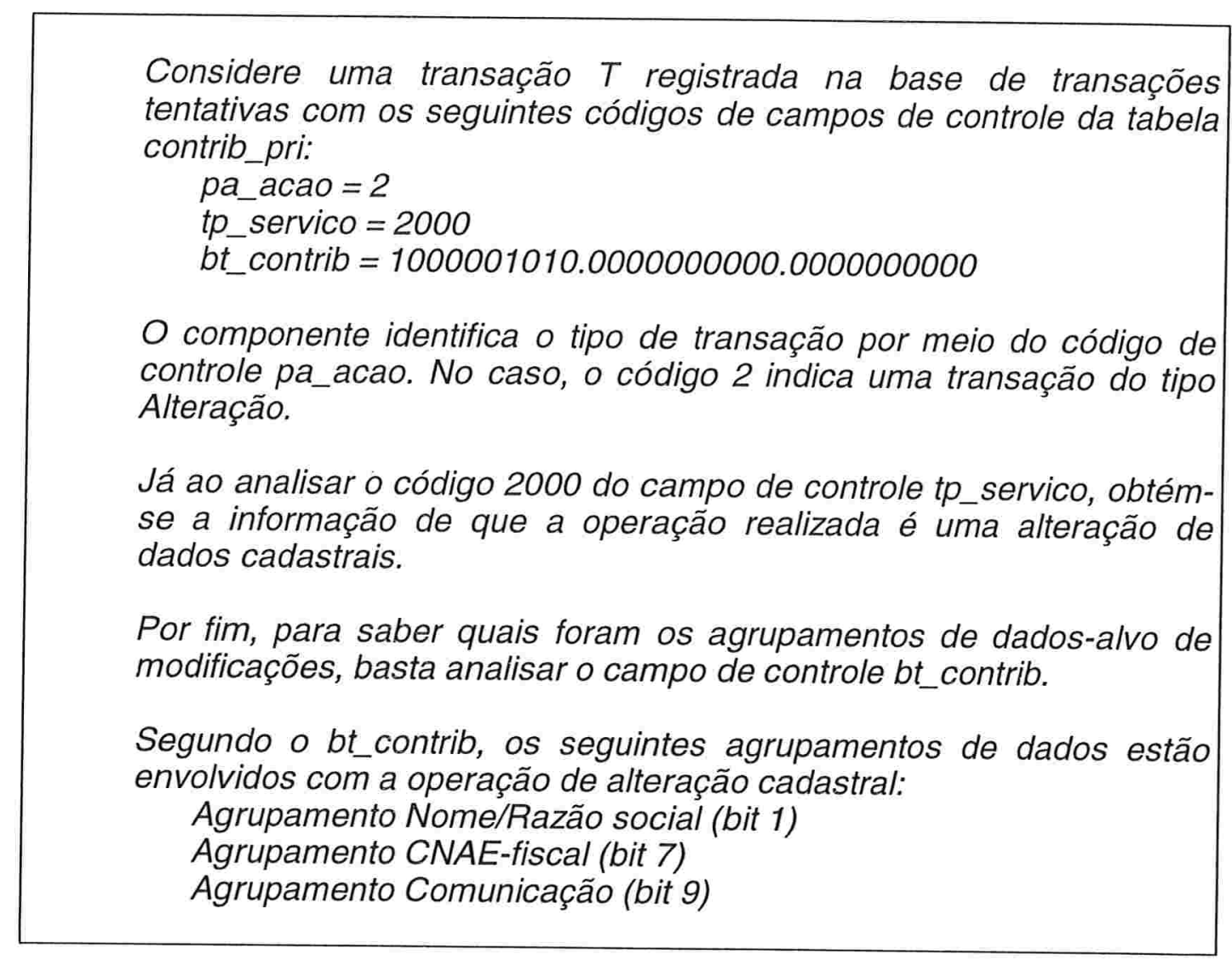

Tabela 25 - Identificação de transação, operação e dados cadastrais envolvidos.

A concepção do sistema DECA Eletrônica foi muito influenciada pelas regras de negócio adotadas. Podemos observar claramente por intermédio das interfaces cadastrais implementadas os agrupamentos de dados e as operações cadastrais existentes.

Para ilustrar como a interface cadastral do sistema DECA Eletrônica representa os agrupamentos de dados, observe abaixo a tela cadastral responsável pela alteração de dados cadastrais. 


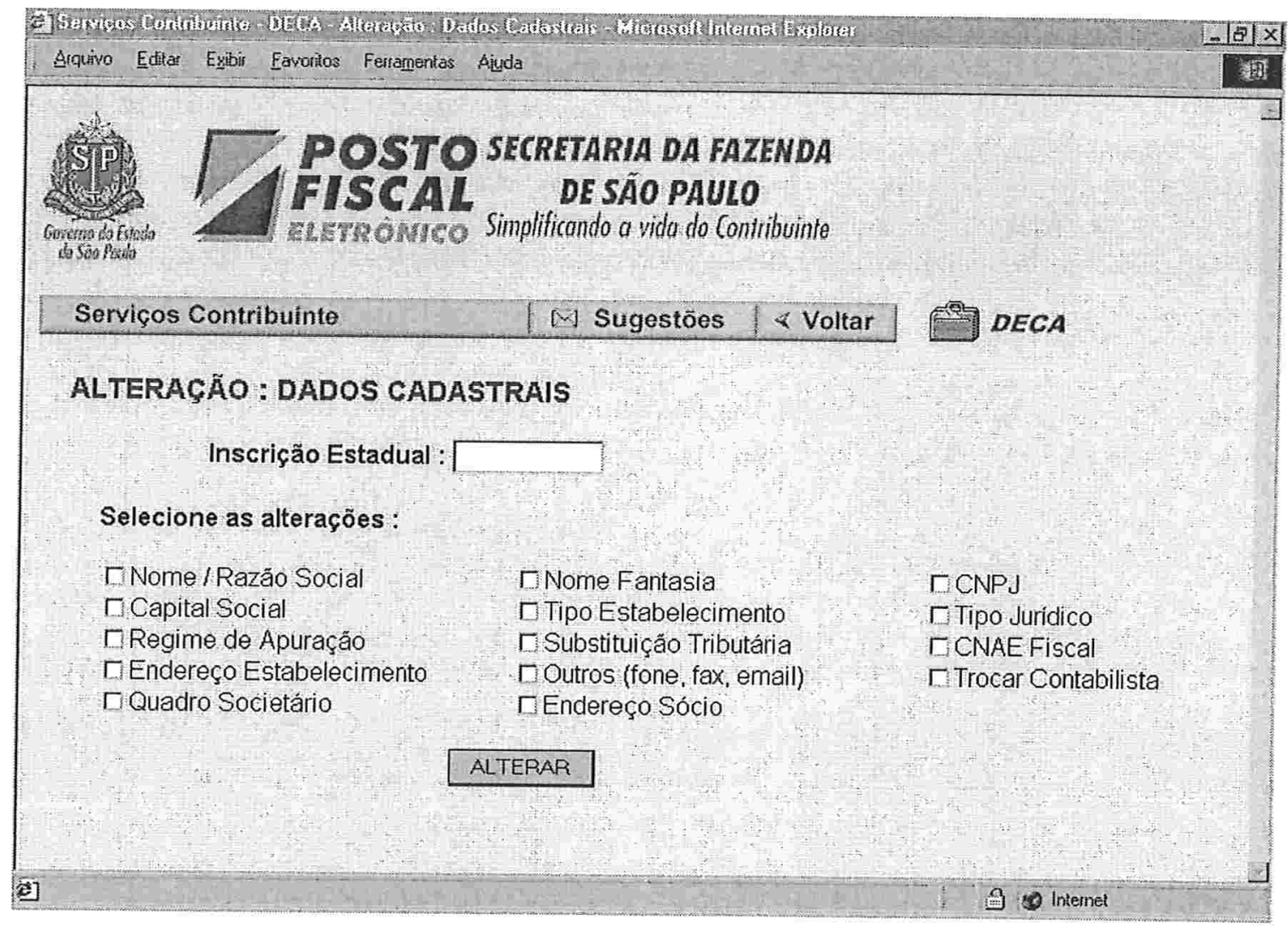

Figura 8 - Tela cadastral da DECA Eletrônica.

Para quase toda operação representada pelo código de controle tp_servico existe uma interface cadastral correspondente no sistema eletrônico DECA. Dependendo da operação realizada existem opções para escolha dos agrupamentos de dados que serão alvo de modificações.

No apêndice 2 são apresentados detalhes das interfaces cadastrais desenvolvidas com o mapeamento das operações cadastrais e dos agrupamentos de dados envolvidos.

Continuando com o processo de quebra transacional, pela análise nos campos de controle o quebrador de transações identifica os agrupamentos de dados envolvidos com as operações cadastrais. As quebras transacionais são baseadas no conjunto de dadosalvo das transações.

Conforme dito anteriormente, foi adotado no sistema DECA Eletrônica o processo de quebra transacional baseado em transações substitutas. Cada subtransação gerada contempla um único agrupamento de dados. Essa regra pode ser modificada caso exista interesse da Sefaz-SP em reagrupar os dados cadastrais em novos agrupamentos de dados.

A quebra transacional é registrada na própria base de transações tentativas central. A transação origem permanece armazenada e fornece informações a respeito dos dados cadastrais e dos campos de controle.

Uma tabela auxiliar foi criada para controle das quebras transacionais. Essa 
tabela utiliza como chave primária a composição do protocolo DECA que identifica a transação origem mais o código do agrupamento de dados envolvido. Existem nessa estrutura campos de controle que registram os status das validações cadastrais realizadas sobre as subtransações geradas.

O exemplo abaixo ilustra a tabela auxiliar denominada quebra_pri que registra a quebra das transações cadastrais e o pseudo-algoritmo da quebra transacional apresentado em 3.3.3.

Considerando a transação $T$ apresentada na tabela anterior, temos os seguintes campos de controle na tabela contrib_pri:

Protocolo pa_acao tp_servico bt_contrib

$123456 \quad 2000 \quad 1000001010.0000000000 .0000000000$

O quebrador de transações identifica pelos códigos de controle que a transação é de alteração de dados cadastrais e que os agrupamentos de dados envolvidos com a operação de alteração são:

Agrupamento Nome/Razão social (bit 1)

Agrupamento CNAE-fiscal (bit 7)

Agrupamento Comunicação (bit 9)

A transação origem $T$ permanece registrada na tabela contrib_pri da base de transações tentativas central. O quebrador de transações realiza a quebra transacional baseando-se nos agrupamentos de dados identificados nos campos de controle.

Assim, a transação $T$ é particionada em 3 subtransações conforme os agrupamentos dos dados envolvidos.

$$
\begin{aligned}
& T_{1}=\text { Transação do agrupamento Nome/Razão social } \\
& T_{2}=\text { Transação do agrupamento CNAE-fiscal } \\
& T_{3}=\text { Transação do agrupamento Comunicação }
\end{aligned}
$$

A tabela quebra_pri pode ser representada da seguinte maneira:

$\begin{array}{lcl}\frac{\text { protocolo }}{123456} & \frac{\text { cod bit }}{1} & \text { situação } \\ 123456 & 7 & \\ 123456 & 9 & \end{array}$

O campo de controle denominado situação representa a validação das subtransações geradas. Os códigos de situação OK, NOK e PDT determinam, respectivamente, as subtransações validadas, não validadas e aguardando validação.

Tabela 26-Quebra transacional.

Após o processo de quebra transacional temos a fase de seriação de transações. Nessa etapa o componente pré-escalonador é o responsável pela aceitação das transações assíncronas. Acompanhe detalhes desse processo no próximo item. 


\subsection{Pré-escalonador (seriador)}

O pré-escalonador é o componente do modelo transacional responsável pela classificação e seriação das transações assíncronas. Utiliza como critério de classificação a Prioridade das Transações, que representa o comportamento transacional representado pelo perfil transacional.

Antes de iniciarmos a descrição do processo de classificação e seriação é necessário apresentar o campo de controle de consistência cadastral da tabela contrib_pri. Esse campo controla se as informações contidas nas transações tentativas são válidas ou não.

Descreveremos brevemente esse processo pois entendemos que o foco deste item é a classificação e seriação de transações. Porém não podemos desconsiderar o fato de que existem mecanismos de validação de dados cadastrais e estruturas na base de transações tentativas central encarregadas de tais consistências.

\section{Controlador de consistência cadastral}

O sistema DECA Eletrônica substituiu por meio de um formulário eletrônico via web a necessidade do comparecimento do contribuinte ao balcão do Posto Fiscal junto com uma infinidade de certidões e documentos para comprovação das informações prestadas.

Como dar garantias às informações prestadas eletronicamente já que as certidões e os documentos comprobatórios não são mais solicitados? Para viabilizar tal procedimento foram firmados convênios para troca de informações com entidades envolvidas no processo de abertura e registro de empresas.

Entre as principais entidades envolvidas nesse processo cadastral destacam-se:

- Jucesp: É o primeiro local onde uma empresa deve se registrar. Contém informações cadastrais de âmbito geral, como: razão social, nome fantasia, capital social, endereço, CNAE-fiscal, tipo jurídico e composição do quadro societário.

- Receita Federal: Esse é o próximo local no qual uma empresa deve se inscrever antes de se registrar na Sefaz-SP. Outras informações cadastrais surgem desse cadastro, como: CNPJ, tipo de estabelecimento e outras informações cadastrais existentes na Jucesp.

- Conselho Regional de Contabilidade de São Paulo (CRC-SP): Órgão que regulamenta as normas de trabalho dos profissionais contadores. Referente às informações cadastrais dos contabilistas das empresas.

Todas as solicitações de modificação cadastral são registradas na base de transações tentativas. Lá permanecem até que obtenham um grau de credibilidade necessário para serem aceitas no sistema.

As entidades acima apresentadas são órgãos que trocam informações cadastrais com a Sefaz-SP. A troca de informações permite ao sistema DECA Eletrônica realizar 
uma série de batimentos e consistências com as informações prestadas pelo contribuinte.

Toda transação é registrada na base de transações tentativas por meio do protocolo DECA. Os batimentos e validações de dados realizados sobre os dados cadastrais são registrados em uma estrutura auxiliar denominada tabela logcontrib_pri que registra todas as consistências e inconsistências existentes envolvendo os dados cadastrais de um protocolo DECA.

O contribuinte, de posse do número do protocolo DECA, pode acompanhar o andamento de sua solicitação por meio de mensagens claras indicando o dado cadastral envolvido, o órgão externo referenciado e a mensagem de validação ou inconsistência existente.

O controlador de consistência cadastral é modificado conforme os diferentes estágios de consistência dos protocolos DECA. O trabalho de comparação dos dados das solicitações com os dados das entidades externas é realizado por um processo denominado monitor.

Os monitores dos sistema DECA Eletrônica são aplicações servidoras desenvolvidas em linguagem $\mathrm{C}++$ que acessam a base de transações tentativas central para selecionar os protocolos DECA. Para cada entidade externa existe um monitor específico.

O controlador de consistência cadastral exerce uma grande influência sobre os monitores pois estes apenas acessam os protocolos DECA que foram compatíveis com a situação de consistência desejada. Não infocaremos aqui a descrição dos diversos monitores bem como das respectivas situações de consistência existentes. Apenas nos são relevantes a existência desses processos de validação e a consistência de dados cadastrais.

Prosseguindo com o processo de seriação de transações assíncronas, consideramos como transações que podem ser alvo de seriação apenas aquelas que obtiveram um grau mínimo de consistência segundo os processos de validação de dados apresentados acima.

O sistema DECA utiliza a base de configuração como princípio do processo de seriação. A base de configuração representa o comportamento transacional do perfil transacional adotado. Baseado nas regras do domínio de aplicação registradas nessa base, o pré-escalonador reclassifica as transações conforme os critérios existentes.

Dentre os critérios existentes no sistema DECA destacam-se:

- Perfil do usuário (contribuinte, contabilista e fiscal);

- Macrooperações (abertura, alteração e recadastramento);

- Operações (aberturas iniciais, alterações cadastrais, ...);

- Agrupamentos de dados (razão social, endereço, ...);

- Pesos transacionais (alto, médio e baixo);

- Grau de consistência da informação (validado ou inconsistente).

Os critérios supramencionados são utilizados pelo pré-escalonador e integrados 
ao processo de seriação de transações através da ordenação de critérios e uso de filtros de seleção.

A ordenação de critérios é utilizada para permitir a escolha da ordem de uso dos critérios no processo de seriação. Dentre os vários critérios apresentados, podemos classificá-los e agrupá-los conforme os interesses definidos pelas regras de negócio.

Abaixo apresentamos um exemplo da escolha de critérios utilizados no sistema DECA Eletrônica.

\begin{tabular}{|c|l|l|l|l|}
\hline Ordem & \multicolumn{1}{|c|}{ Usuário } & Macrooperação & \multicolumn{1}{c|}{ Operação } & \multicolumn{1}{c|}{ Agrupamento } \\
\hline 1 & Fiscal & Alteração & DECA ofício & CNAE-fiscal \\
\hline 2 & Fiscal & Alteração & DECA corretiva & Data CNAE-fiscal \\
\hline 3 & Contribuinte & Alteração & Dados cadastrais & CNAE-fiscal \\
\hline
\end{tabular}

Tabela 27 - Ordenação dos critérios a serem usados na classificação de transações.

Essa estrutura pertence à base de configuração pois representa o comportamento transacional adotado no que se refere à seriação de transações assíncronas. Podemos utilizar também os filtros de seleção ao processo de reclassificação de transações.

No exemplo anterior, poderíamos restringir as informações do agrupamento CNAE-fiscal para atender apenas às solicitações das CNAEs-fiscais que fossem relacionadas a um respectivo conjunto de atividades econômicas ou mesmo a um conjunto específico de fiscais que fazem parte da categoria de usuários fiscais.

Todas as estruturas acima mencionadas contêm informações que fazem parte do cálculo da prioridade das transações. Após o cálculo da prioridade e registro dos protocolos DECA, segundo a estrutura apresentada na tabela 17 do item 4.3 referente ao conceito de prioridade das transações, as transações são classificadas seguindo a ordenação obtida. É baseado nessa classificação que o processo de seriação acontece.

No sistema DECA, as transações classificadas pelo pré-escalonador que conflitam com solicitações de outros usuários sobre o mesmo agrupamento de dados são abortadas conforme decisão da equipe de negócios. O intuito em desconsiderar tais solicitações é evitar possíveis conflitos que ocorram entre as transações.

Nessa situação, o processo de seriação elege, conforme as regras do domínio de aplicação, as transações conflitantes que apresentam maior prioridade para a Sefaz-SP.

O processo de seriação acima descrito referencia o pseudo-algoritmo de seriação de transações apresentado em 3.3.4.

Outros perfis transacionais utilizam critérios de classificação diferentes e podem adotar soluções para a seriação de transações conflitantes distintas da decisão de negação. São exemplos de outras soluções de seriação o uso de transações substitutas e condicionais.

Seja qual for a decisão a respeito do processo de reclassificação de transações, estas são seriadas conforme a ordem estabelecida e respeitam as regras de negócio. No final, o resultado de todo o processo é registrado na base de transações tentativas 
central.

No sistema DECA Eletrônica a atualização da base da aplicação é realizada por um monitor que analisa a base de transações tentativas central em busca de transações aceitas pelo seriador de transações.

\subsection{Resultados obtidos}

Neste item apresentamos alguns resultados obtidos com a implantação do sistema DECA Eletrônica no âmbito da Sefaz-SP.

Além das metas alcançadas com a realização dos objetivos, funcionalidades e características operacionais, apresentamos, a seguir, alguns dados [37] que servem como indicadores primários dos resultados positivos da implantação do portal cadastral paulista:

- no período de 1997 a 1999 o percentual do tempo de atendimento somente para o documento DECA ocupava cerca de $40 \%$ a $50 \%$ do tempo total dos serviços prestados nas unidades fiscais. Nos anos seguintes à implantação do portal cadastral paulista, os percentuais baixaram para a faixa dos $10 \%$ a $20 \%$;

- o número de unidades fiscais físicas que no biênio 97-98 era de 253 PFs, baixou no biênio seguinte para 170 PFs (Postos Fiscais) em decorrência da implantação do PFE, do "Simples Paulista"6, da transmissão de outros documentos via Internet, e criação das Unidades de Atendimento ao Público (UAP) nas Prefeituras. Com a implantação total da DECA Eletrônica, hoje estão em atividade 140 PFs no estado, com perspectiva de diminuição com a implantação de novos sistemas. Ou seja, diminuição significativa de custos fixos e administrativos e melhoria dos serviços cadastrais;

- suspensão da cobrança de taxa de emissão da Ficha de Inscrição Cadastral (FIC), tornando todas as operações cadastrais desoneradas de pagamento de taxas e emolumentos;

- o número de aberturas de empresas no estado manteve-se num mesmo patamar, girando sua quantidade na faixa de 5000 a 10000 aberturas/mês. Já o volume de alterações cadastrais saiu da faixa de 5000, atingindo a faixa de 20000 a 30000 alterações/mês. Estes números podem indicar que a morosidade e o custo processual de uma alteração ou atualização cadastral das empresas em São Paulo inibiam estas operações. E como o fisco paulista não dispunha de informações cadastrais de seus contribuintes devidamente atualizadas, os resultados das ações fiscais eram sempre prejudicados;

- a central de atendimentos telefônicos da Sefaz-SP recebeu, quando implantou-se a DECA em junho de 2000, cerca de 18000 telefonemas solicitando o esclarecimento de dúvidas gerais dos usuários. Uma vez assimilado o sistema pelos usuários, o número de telefonemas pedindo algum tipo de explicação sobre a DECA Eletrônica baixou para a faixa de 1000 a 2000 ligações/mês;

- a quantidade de funcionários administrativos prestando serviços ligados ao

${ }^{6}$ O Simples Paulista antecedeu à implantação do sistema DECA Eletrônica e corresponde à parte do núcleo das consistências da DECA relacionadas ao regime de apuração. O Simples Paulista divide-se em Microempresas (ME) e Empresas de Pequeno Porte classes A e B (EPP-A e EPP-B). 
atendimento ao público nos PFs de todo o Estado girava em torno de 1000 a 1200. Cerca de $30 \%$ a $40 \%$ deste contingente já está trabalhando diretamente no apoio às ações da fiscalização, tendo deixado funções burocráticas improdutivas. 


\section{Conclusão}

\subsection{Resumo}

Existem muitos estudos relacionados ao tratamento da integração de transações conflitantes [15, 17, 30, 31, 32, 33, 34, 35]. Nestes, diversos algoritmos de resolução de conflitos foram desenvolvidos, baseados nas mais diversas técnicas de sincronização de transações. Recentemente, alguns estudos têm se direcionado ao cálculo da métrica da inconsistência existente entre os bancos de dados, como critério para a integração de transações conflitantes [21, 26, 27, 28, 29]. Nessa linha de pesquisa, direcionamos nossos estudos com o intuito de encontrar meios ou critérios que possam ser estabelecidos, para auxiliar na resolução ou diminuição dos problemas de integração de transações conflitantes. Acreditamos que com um forte conhecimento do modelo de partição de transações submetidas ao banco de dados, juntamente com a definição de critérios que especifiquem as regras de partição, é possível estabelecer semânticas de separação que restringirão o grau de inconsistência existente entre as instâncias de bancos de dados, facilitando assim a integração de transações conflitantes.

O uso da porcentagem de aceite e prioridade para cada nova subtransação gerada a partir de uma transação global é muito bem aceito junto a sistemas que têm como requisitos o controle do fluxo de transações.

Nesse contexto, a porcentagem de aceite atribui às transações uma característica relacionada a inconsistência. Uma transação com alta porcentagem de aceite apresenta uma pequena inconsistência nas informações. Com a redifinição da prioridade das subtransações podemos cancelar ou então confirmar tal subtransação, ciente da violação do princípio da seriação em questão.

Dessa maneira, um sistema pode considerar que uma determinada transação já encontra-se validada enquanto outro pode descartar as modificações realizadas pela transação, por causa de um resultado que reflete em uma baixa porcentagem de aceite.

Diversos sistemas podem compartilhar um mesmo controle de fluxo de informação. Nesse caso, cada sistema adota regras de negócio diferentes que refletem no cálculo da porcentagem de aceite e prioridades das subtransações. Assim, dependendo das configurações existentes em cada sistema, uma mesma transação pode apresentar configurações distintas.

Nossa proposta objetivou flexibilizar as formas de partição das transações de modo a criar um conjunto de parâmetros para representar uma "meta"-controle do fluxo de informações.

O uso de modelos transacionais parametrizados é indicado para sistemas baseados em controle de fluxo de informação como integradores de sistemas. Exemplos de aplicações que podem se beneficiar desse modelo são sistemas de venda e sistemas de unificação cadastral. Na seção 4, "Exemplo de aplicação do modelo transacional", referente à implementação da solução proposta, descrevemos um sistema cadastral dá Secretaria de Estado dos Negócios da Fazenda do Estado de São Paulo (Sefaz-SP), exemplificando diversas situações na qual o sistema existente se beneficia das vantagens do uso do modelo transacional proposto. 
Entendemos que esta flexibilização e parametrização transacional pode ser aplicada a um novo conceito em desenvolvimento denominado originalmente de "information flow".

\subsection{Contribuições relevantes}

\section{Contribuição para flexibilização das aplicações}

Com a flexibilização do modelo transacional, as aplicações foram implementadas de modo a melhor se adaptar ao modelo de negócio. Assim o PFE que sintetiza o conjunto de aplicações que se beneficiou da nossa proposta obteve vários reconhecimentos.

O PFE, sítio onde encontra-se o sistema DECA Eletrônica, foi reconhecido internacionalmente junto aos diversos orgãos que patrocinaram o seu desenvolvimento. Entre eles destacam-se o BID (Banco Interamericano de Desenvolvimento) e o PNUD (Programa das Nações Unidas para o Desenvolvimento).

Diversos foram os prêmios recebidos durantes esses anos. Como destaque em 2001 o PFE foi reconhecido como a melhor aplicação cadastral da área pública na internet recebendo o prêmio CONIP2001 (Concurso Nacional de Informática Pública).

O projeto DECA Eletrônica da Sefaz-SP tornou-se referência de modernização às demais Secretarias da Fazenda dos outros estados da Federação. Várias propostas surgiram e diversos serviços governamentais estão sendo informatizados baseados na flexibilidade do modelo transacional proposto.

Atualmente a Sefaz-SP busca ampliar seu projeto cadastral para o âmbito federal. Uma parceria foi estabelecida com a Receita Federal com o intuito de unificar a entrada de informações cadastrais nas duas instituições.

\section{Contribuição para o modelo transacional}

A nossa proposta introduz dois parâmetros nas transações partidas:

$$
\mathbf{T}=\bigcup t_{i} p_{j} a_{k}
$$

Com essa definição, o conceito de ordem parcial e de escalonamento foi revisto em 3.2. Os componentes foram implementados em 3.3 e utilizados na aplicação descrita em 4.

\subsection{Futuras pesquisas}

Este trabalho pode ser generalizado do ponto de vista conceitual, analisando os conceitos transacionais apresentados sob uma nova forma de controle de fluxo de dados e processos denominado "information flow." Portanto, como próximo passo, pretendemos analisar a viabilidade da inclusão do conceito de transação parametrizada, apresentado nesse trabalho, para o controle de fluxo de informação. Do ponto de vista de 
implementação, pode-se generalizar o componente, apresentado neste trabalho, de modo a incluí-lo na arquitetura J2EE. 


\section{Bibliografia}

[1] B. R. Badrinath and K. Ramamritham, Performance evaluation of semantics-based multilevel concurrency control protocols, ACM SIGMOD International Conference on Management of Data (37/206), pages 163-172, May 1990.

[2] A. J. Demers, K. Petersen, M. J. Spreitzer, D. B. Terry, M. M. Theimer and B. Welch, The Bayou architecture: support for data sharing among mobile users, Proc. of the IEEE Workshop on Mobile Computing and Applications, pages 2-7, Dec. 1994.

[3] K. Petersen, M. J. Spreitzer, D. B. Terry, M. M. Theimer, A. J. Demers. Flexible update propagation for weakly consistent replication. Proceedings of the $16^{\text {th }}$ ACM Symposium on Operation Systems Principles, Saint Malo, France, pages 288-301, October 1997.

[4] J. Gray, P. Helland, P. E. O'Neil and D. Shasha. The dangers of replication and a solution. Proceedings of ACM SIGMOD, pages 173-182, June 1996.

[5] S. H. Phatak and B. R. Badrinath, Database server organization for handling mobile clients, Department of Computer Science Technical report DCS-TR-324, Department of Computer Science, Rutgers University, New Jersey, 1997.

[6] S. H. Phatak and B. R. Badrinath, An architecture for mobile databases, Department of Computer Science Technical Report DCS-TR-351, Department of Computer Science, Rutgers University, New Jersey, 1998.

[7] S. H. Phatak and B. R. Badrinath, Multiversion reconciliation for mobile databases, Proc. of the International Conference on Data Engineering (ICDE), Sydney, Australia, pages 582-589, Mar.1999.

[8] S. H. Phatak and B. R. Badrinath, Data partitioning for disconnected client server databases, Proc. of the International Workshop on Data Engineering for Wireless and Mobile Access (MobiDE'99), Seattle, Washington, Aug.1999.

[9] S. H. Phatak and B. R. Badrinath, Conflict resolution and reconciliation in disconnected databases, Proc. of the Mobility in Databases and Distributed Systems (MDDS), Florence, Italy, Sep. 1999.

[10] IBM Cloudscape, Inc., IBM ${ }^{\circledR}$, versão 5.0. Sítio: http://www.cloudscape.com

[11] Borland $^{\circledR}$, JdataStore ${ }^{\mathrm{TM}}$, versão 6.0, Inprise Corporation. Sítio: http:// www.borland.com/jdatastore

[12] Richard Lenz, The "Virtual-Primary-Copy-Approach" compared to other approaches with weak consistent data replication, University of Erlangen Nuremberg, 1996. 
[13] Kistler, J. and Satyanarayanan, M. Disconnected operation in the Coda file system. In ACM Transactions on Computer Systems, vol. 10, n.1, pages 3-25, Feb. 1992.

[14] R. Guy, J. Heidemann, W. Mak, T. Page Jr., G. Popek, D. RotyMeier. Implementation of the Ficus Replicated File System. The Proceedings of the Summer USENIX Conference, páginas 63-71, Anaheim, CA, June 1990.

[15] João Eduardo Ferreira e Marcelo Finger, Controle de concorrência e distribuição de dados: a teoria clássica, suas limitações e extensões modernas, $12^{a}$ Escola de Computação, IME - USP, 2000.

[16] Abdelsalam A. Helal, Abdelsalam A. Heddaya and Bharat B. Bhargava, Replication Techniques in Distributed Systems, Kluwer Academic Publishers, 1996.

[17] P. A. Bernstein, V. Hadzilacos, N. Goodman. Concurrency Control and Recovery in Database Systems. Addison-Wesley, Reading, Massachusetts, 1987.

[18] Veijalainen, J. Transaction Concepts in Autonomous Database Environments. R. Oldenbourg Verlag, Munich, 1989.

[19] T. Imielinski and B. R. Badrinath, "Mobile wireless computing: challenges in data management", Communications of the ACM, vol. 37, n. 10, pp. 19-28, October 1994.

[20] Infosphere Project: System Support for Information Flow Applications, by C. Pu, K. Schwan, J. Walpole. ACM SIGMOD Record, vol. 30, n. 1, March 2001.

[21] K. L. Wu, P. S. Yu and C. Pu, "Divergence Control for Epsilon Serializability", In Proceedings of Eighth International Conference on Data Engineering, pp. 506-515, Phoenix, February 1992.

[22] Barbara, Daniel, Mobile Computing and Databases - A Survey, IEEE Transactions on Knowledge and Data Engineering, vol.11, n.1, January/February 1999.

[23] Sun Microsystems. Java 2 Plataform Enterprise Edition Specification, v 1.3. Final Release. August, 2001. Sítio: http://java.sun.com/j2ee/download.html\#platformspec

[24] Enterprise Java Beans Technology. Sítio: http://java.sun.com/products/ejb/

[25] Transactions. Sítio: http://java.sun.com/j2ee/transactions.html

[26] A. Leff and C. Pu, "Autonomous Transaction Execution with Epsilon Serializability", Proceedings of 1992 RIDE Workshop on Transaction and Query Processing, IEEE/Computer Society, Phoenix, February 1992.

[27] Calton $\mathrm{Pu}$, "Relaxing the Limitations of Serializable Transactions in Distributed Systems", Operating Systems Review, ACM SIGOPS, 27(2):66-71, April 1993. Also appeared in the Proceedings of 5th ACM SIGOPS European Workshop, Le Mont Saint-Michel, France, 1992. 
[28] Pamela Drew and Calton Pu, "Asychronous Consistency Restoration under Epsilon Serializability", Proceedings of the $28^{\text {th }}$ Hawaiian International Conference on Systems Sciences, Jan. 1995.

[29] Krithi Ramamritham and Calton Pu, "A Formal Characterization of Epsilon Serializability", IEEE Transactions on Knowledge and Data Engineering, IEEE Computer Society, December 1995.

[30] Rob Goldring, Things every update replication customer should know, ACM SIGMOD, 1995, San Jose, CA, USA.

[31] Yuri Breitbart, Henry F. Korth, Replication and consistency: being lazy helps sometimes, ACM PODS'97, Tucson, Arizona, USA.

[32] Todd Anderson, Yuri Breitbart, Henry F. Korth, Avishai Wool, Replication, consistency and practicality: are these mutually exclusive? ACM SIGMOD, 1998, Seattle, Washington, USA.

[33] Rivka Ladin, Barbara Liskov, Sanjay Gttemwat, Providing high availability using lazy replication, ACM Transaction on Computer Systems, 1992.

[34] Sharad Mehrotra, Rajeev Rastogi, Yuri Breitbart, Henry F. Korth, Avi Silberschatz, Ensuring transaction atomicity in multidatabase systems, $11^{\text {th }}$ Principles of Database Systems, San Diego, CA, ACM, 1992.

[35] Cristian Ionitoiu, Birger Andersen, Replicated objects with lazy consistency, ECCOP'96, II Workshop on Mobility and Replication.

[36] C. Pu, G. Kaiser and N. Hutchinson. Split-transactions for open-ended activities. In Proceedings of the $14^{\text {th }}$ VLDB Conference, 1988.

[37] Netto, Francisco S., Zuliani, Devanir, Braz, Edson. "DECA Eletrônica: inovações e impactos decorrentes da implantação do portal cadastral de serviços públicos no Estado de São Paulo". Em: ENANPAD, n. 26, Salvador, 2002. Audis, Rio de Janeiro: ANPAD, Outubro 2002. CD-ROM. 


\section{Apêndice 1: glossário de termos do sistema DECA Eletrônica}

A seguir relacionamos os termos técnicos envolvidos no sistema DECA Eletrônica e apresentados nessa dissertação.

\begin{tabular}{|c|c|}
\hline Termo & Descrição \\
\hline BID & $\begin{array}{l}\text { Banco Interamericano de Desenvolvimento. Financiou junto ao PNUD } \\
\text { o projeto de modernização dos serviços de atendimento aos } \\
\text { contribuintes da Sefaz-SP. }\end{array}$ \\
\hline Cancelamento & $\begin{array}{l}\text { Processo que consiste no cancelamento das atividades do } \\
\text { contribuinte. }\end{array}$ \\
\hline CNAE-fiscal & $\begin{array}{l}\text { O CNAE-fiscal é composto pelo código CNAE (Código Nacional de } \\
\text { Atividade Econômica) mais três dígitos referentes ao mapeamento da } \\
\text { atividade no âmbito da Sefaz-SP. }\end{array}$ \\
\hline CNPJ & Código Nacional de Pessoa Jurídica. Fonte: Receita Federal. \\
\hline CONIP & $\begin{array}{l}\text { Concurso Nacional de Informática Pública. Concedeu em } 2001 \text { um } \\
\text { prêmio de reconhecimento à qualidade do sistema DECA Eletrônica. }\end{array}$ \\
\hline Contribuinte & Empresa inscrita no cadastro do ICMS paulista (DECA). \\
\hline CRC & $\begin{array}{l}\text { Conselho Regional de Contabilidade. Também referenciado no texto } \\
\text { como o código do profissional de contabilidade que encontra-se } \\
\text { registrado em tal órgão. }\end{array}$ \\
\hline DECA & DEclaração CAdastral dos contribuintes paulistas do ICMS. \\
\hline DECA corretiva & $\begin{array}{l}\text { Alteração cadastral de caráter corretivo realizado pelo fisco, por } \\
\text { solicitação do contribuinte ou por verificação fiscal. }\end{array}$ \\
\hline DECA ofício & $\begin{array}{l}\text { Alteração cadastral realizada pelo fisco, por solicitação do } \\
\text { contribuinte ou por imposição fiscal. }\end{array}$ \\
\hline ICMS & $\begin{array}{l}\text { Imposto sobre Circulação de Mercadorias e Serviços. Fonte: } \\
\text { Secretaria de Estado dos Negócios da Fazenda de São Paulo (Sefaz- } \\
\text { SP). }\end{array}$ \\
\hline Jucesp & Junta Comercial do Estado de São Paulo. \\
\hline NIRE & $\begin{array}{l}\text { Número de Identificação de Registro. Fonte: Junta Comercial do } \\
\text { Estado de São Paulo (Jucesp). }\end{array}$ \\
\hline PFE & $\begin{array}{l}\text { Posto Fiscal Eletrônico. Sítio que hospeda diversos serviços } \\
\text { eletrônicos, dentre eles a DECA Eletrônica. }\end{array}$ \\
\hline PNUD & $\begin{array}{l}\text { Programa das Nações Unidas para o Desenvolvimento. Financiou } \\
\text { junto ao BID o projeto de modernização da Sefaz-SP. }\end{array}$ \\
\hline Posto fiscal & $\begin{array}{l}\text { Repartições da Sefaz-SP responsáveis pelo atendimento ao } \\
\text { contribuinte. Atualmente seu número aproximado é de } 170 \text { postos } \\
\text { fiscais (PF) espalhados pelo Estado de São Paulo. }\end{array}$ \\
\hline Promocat & $\begin{array}{l}\text { Projeto de Modernização da Coordenadoria de Administração } \\
\text { Tributária. Projeto que viabilizou a criação do PFE e dos diversos } \\
\text { serviços eletrônicos que nele se encontram. }\end{array}$ \\
\hline $\begin{array}{l}\text { Reativação } \\
\text { suspensão }\end{array}$ & $\begin{array}{l}\text { Processo que consiste reativação da atividade de um contribuinte } \\
\text { suspenso. }\end{array}$ \\
\hline $\begin{array}{l}\text { Regime } \\
\text { apuração }\end{array}$ & $\begin{array}{l}\text { Código referente ao recolhimento de impostos e incidência de } \\
\text { tributação. Classificam-se em: Microempresa (ME), Empresa de } \\
\text { Pequeno Porte Classes A e B (EPP-A e EPP-B) e Regime Períodico } \\
\text { de Apuração (RPA). }\end{array}$ \\
\hline
\end{tabular}




\begin{tabular}{|l|l|}
\hline $\begin{array}{l}\text { Restabelecimento } \\
\text { da eficácia }\end{array}$ & $\begin{array}{l}\text { Processo que consiste reativação da atividade de um contribuinte } \\
\text { cassado. }\end{array}$ \\
\hline Sefaz-SP & Secretaria de Estado dos Negócios da Fazenda de São Paulo. \\
\hline Suspensão & Processo que consiste na suspensão das atividades do contribuinte. \\
\hline Tipo jurídico & $\begin{array}{l}\text { Classificação jurídica do tipo da empresa. Dependendo da } \\
\text { classificação, os papéis da composição do quadro societário são } \\
\text { diferenciados. São exemplos dos tipos jurídicos: Firma individual, } \\
\text { Limitada, Sociedade anônima e Cooperativa. }\end{array}$ \\
\hline $\begin{array}{l}\text { Transferência de } \\
\text { estabelecimento }\end{array}$ & $\begin{array}{l}\text { Processo que consiste na troca de todo o quadro societário de uma } \\
\text { empresa inscrita no cadastro DECA. }\end{array}$ \\
\hline
\end{tabular}




\section{Apêndice 2: interfaces cadastrais do sistema DECA Eletrônica}

Apresentamos nesse apêndice algumas interfaces cadastrais desenvolvidas no sistema DECA Eletrônica. O intuito desta seção é mostrar as telas cadastrais ressaltando os tipos de operações existentes, bem como os conjuntos de dados cadastrais envolvidos.

\section{Abertura: inicial}

Constitui a etapa cadastral utilizada pelas empresas que desejam se inscrever no cadastro de contribuintes do ICMS paulista. As telas cadastrais abaixo apresentadas detalham a seqüência de telas existentes nesse processo.

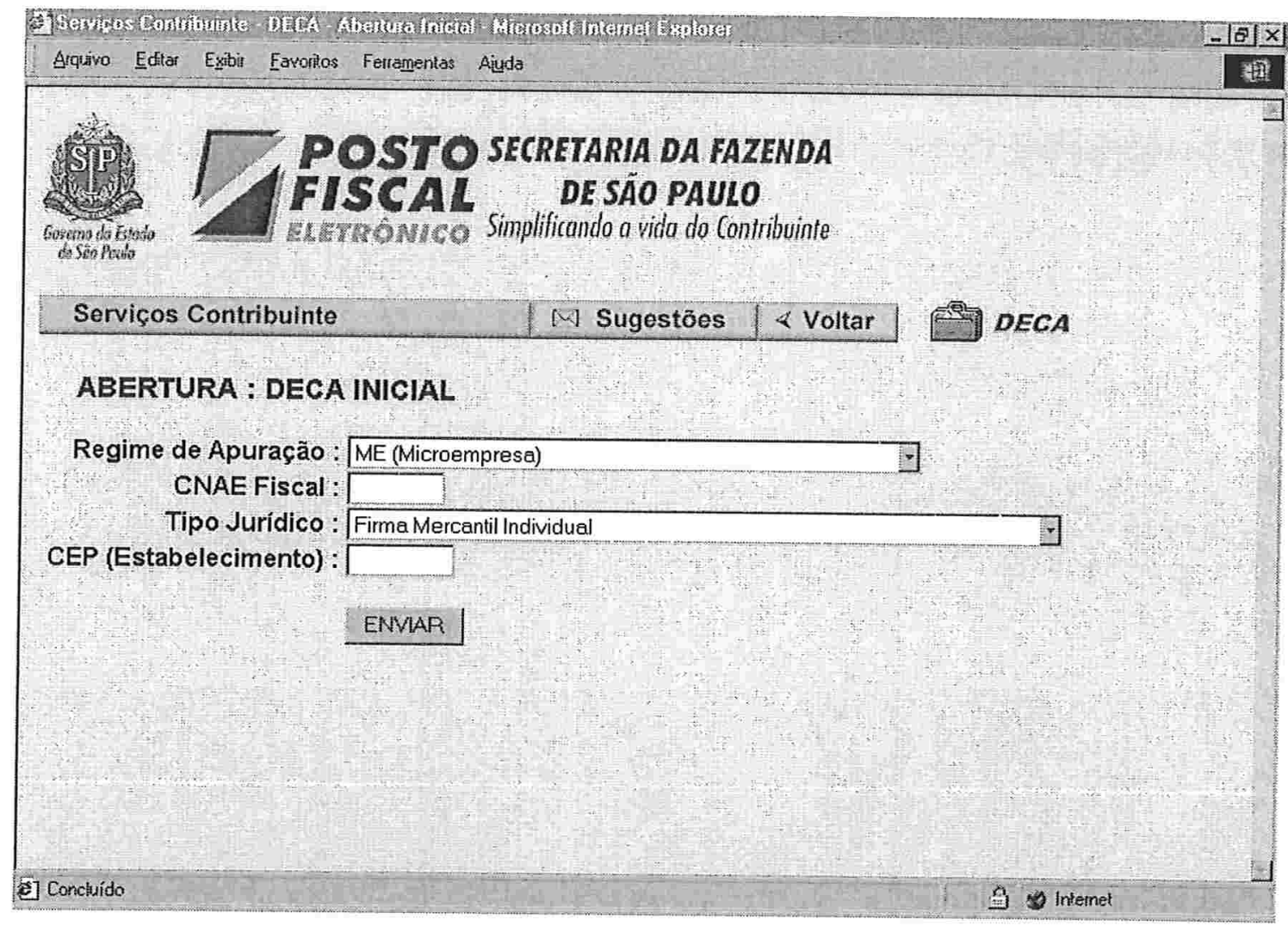

Figura 9 - Tela inicial da abertura de empresas no cadastro da SEFAZ-SP.

Após o envio de requisição da tela inicial de abertura acima apresentada, o contribuinte recebe o formulário eletrônico contendo todas as informações cadastrais necessárias ao registro da empresa no cadastro da Sefaz-SP.

Vale ressaltar, nas telas de formulário apresentadas a seguir, os agrupamentos de dados existentes que são mapeados pelo perfil transacional de aplicação cadastral. Tais mapeamentos de dados são usados no processo de quebra transacional. 


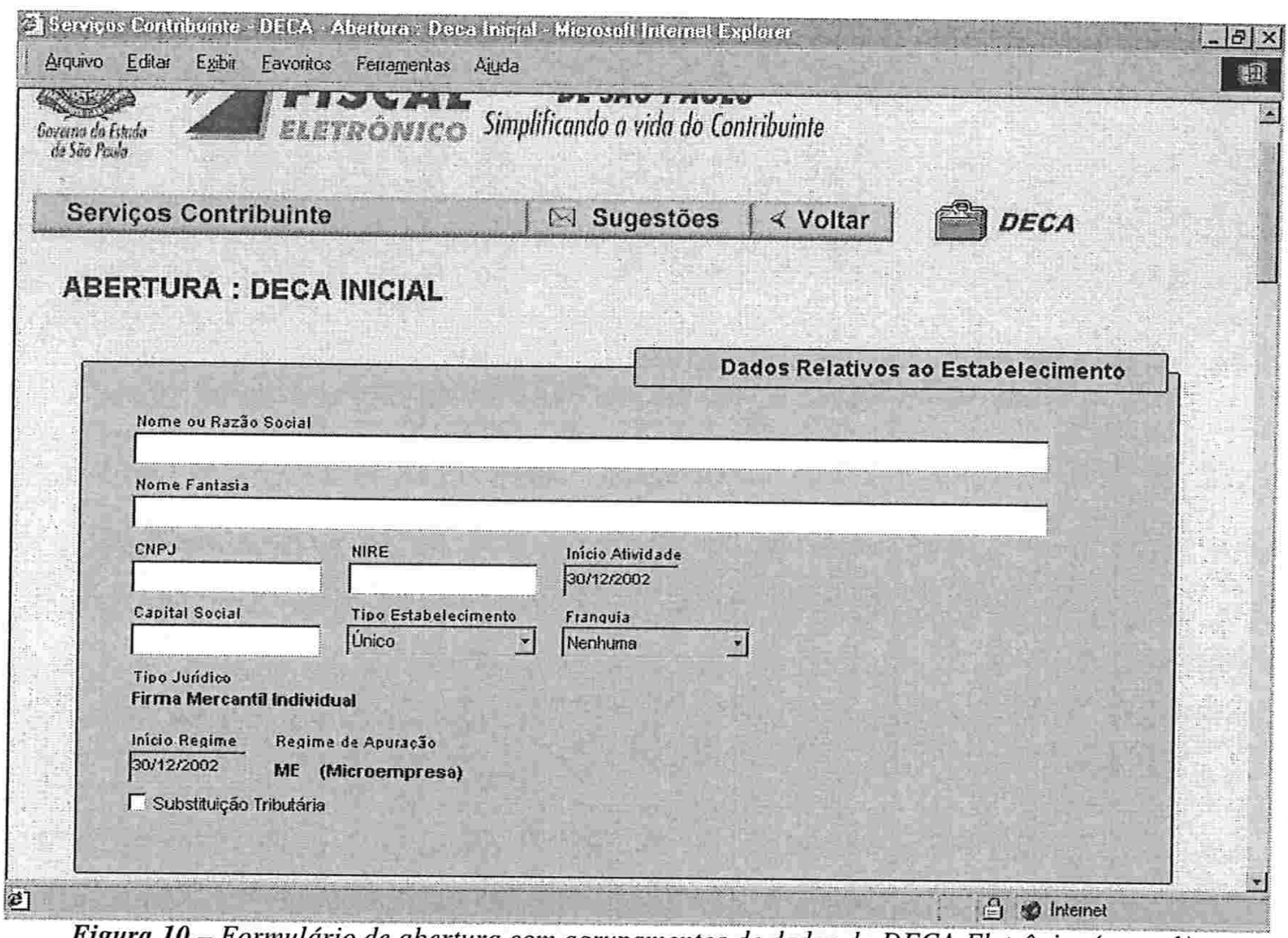

Figura 10 - Formulário de abertura com agrupamentos de dados da DECA Eletrônica (parte 1).

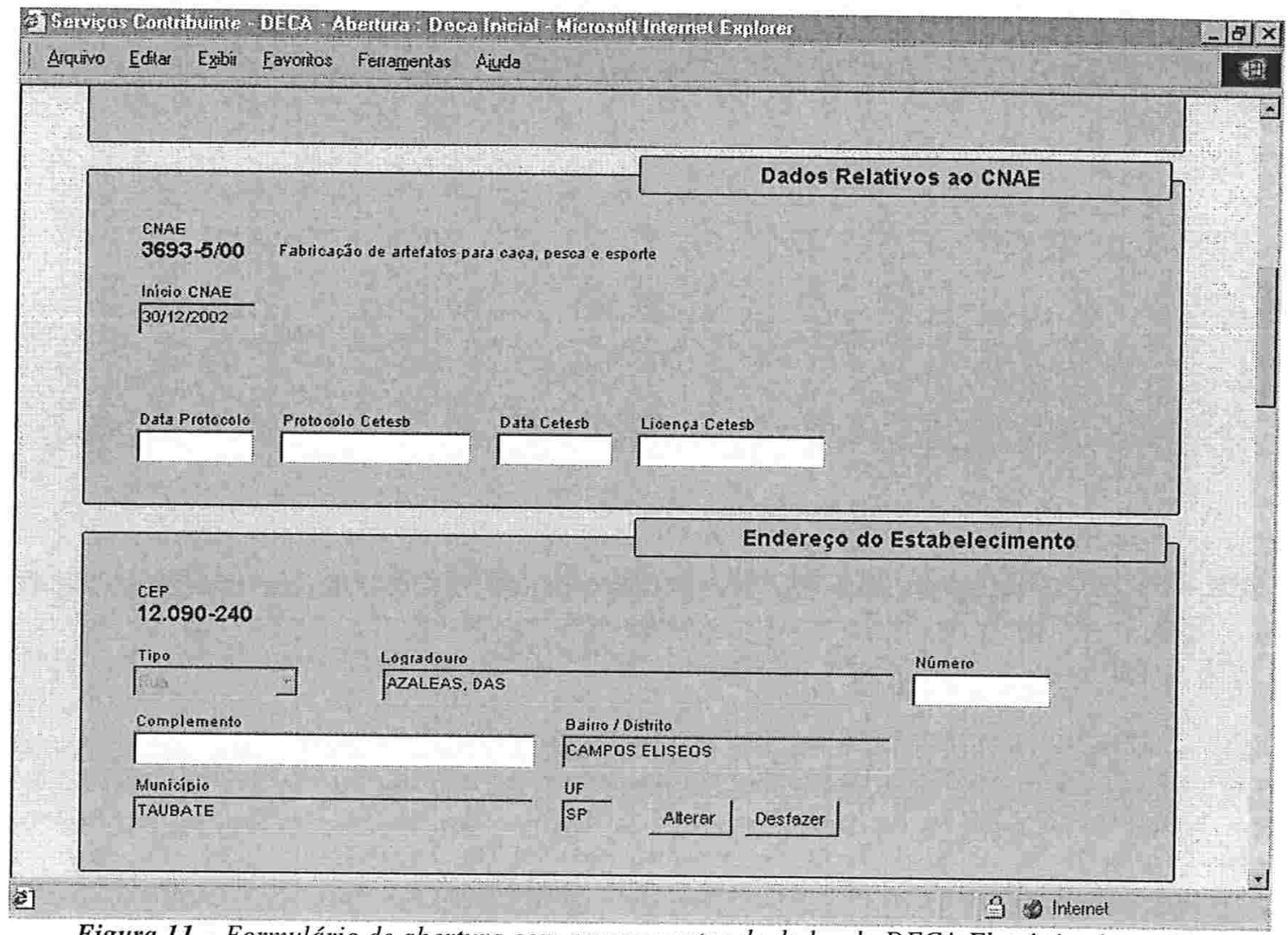

Figura 11 - Formulário de abertura com agrupamentos de dados da DECA Eletrônica (parte 2). 


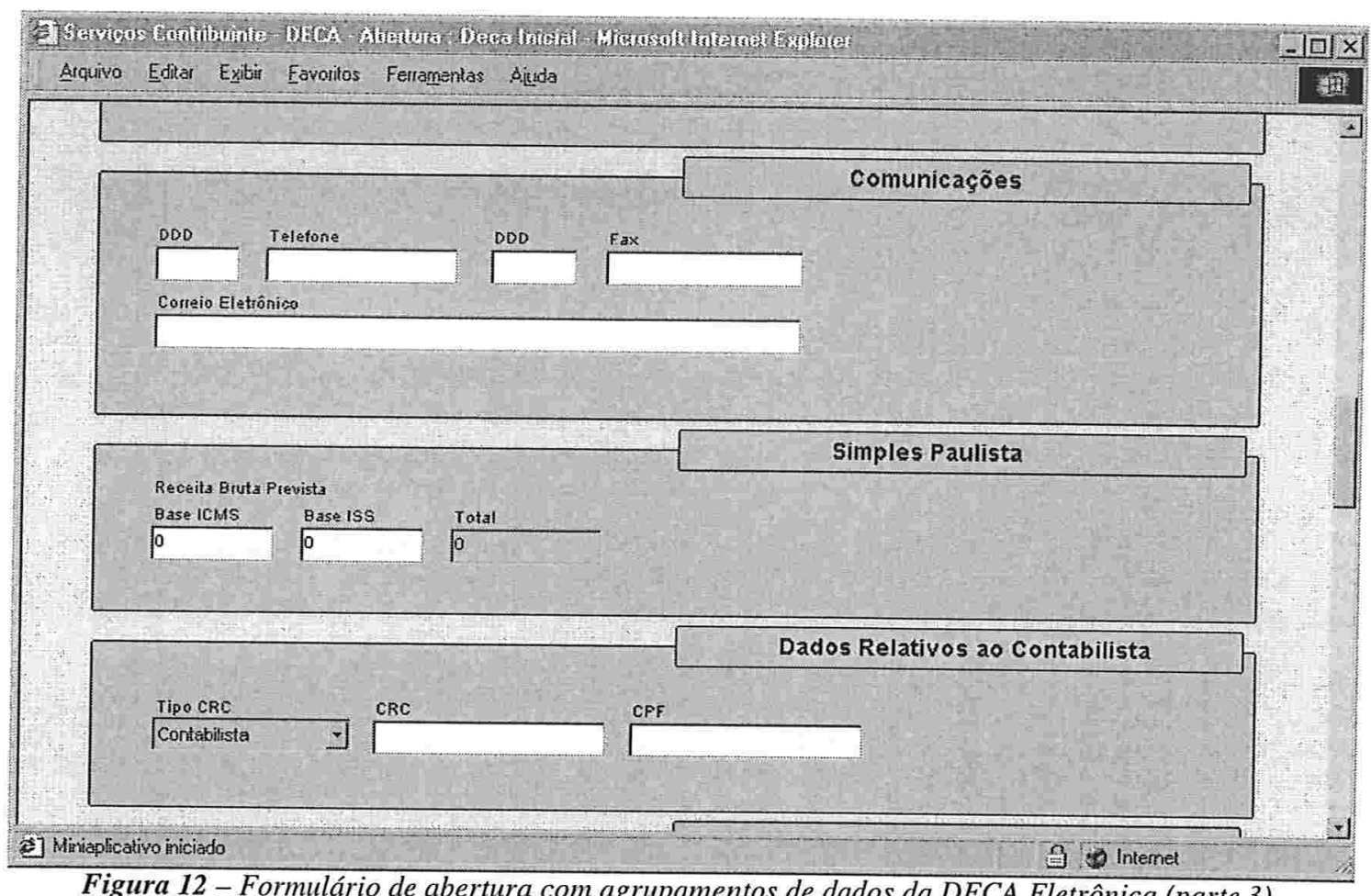

Figura 12 - Formulário de abertura com agrupamentos de dados da DECA Eletrônica (parte 3).

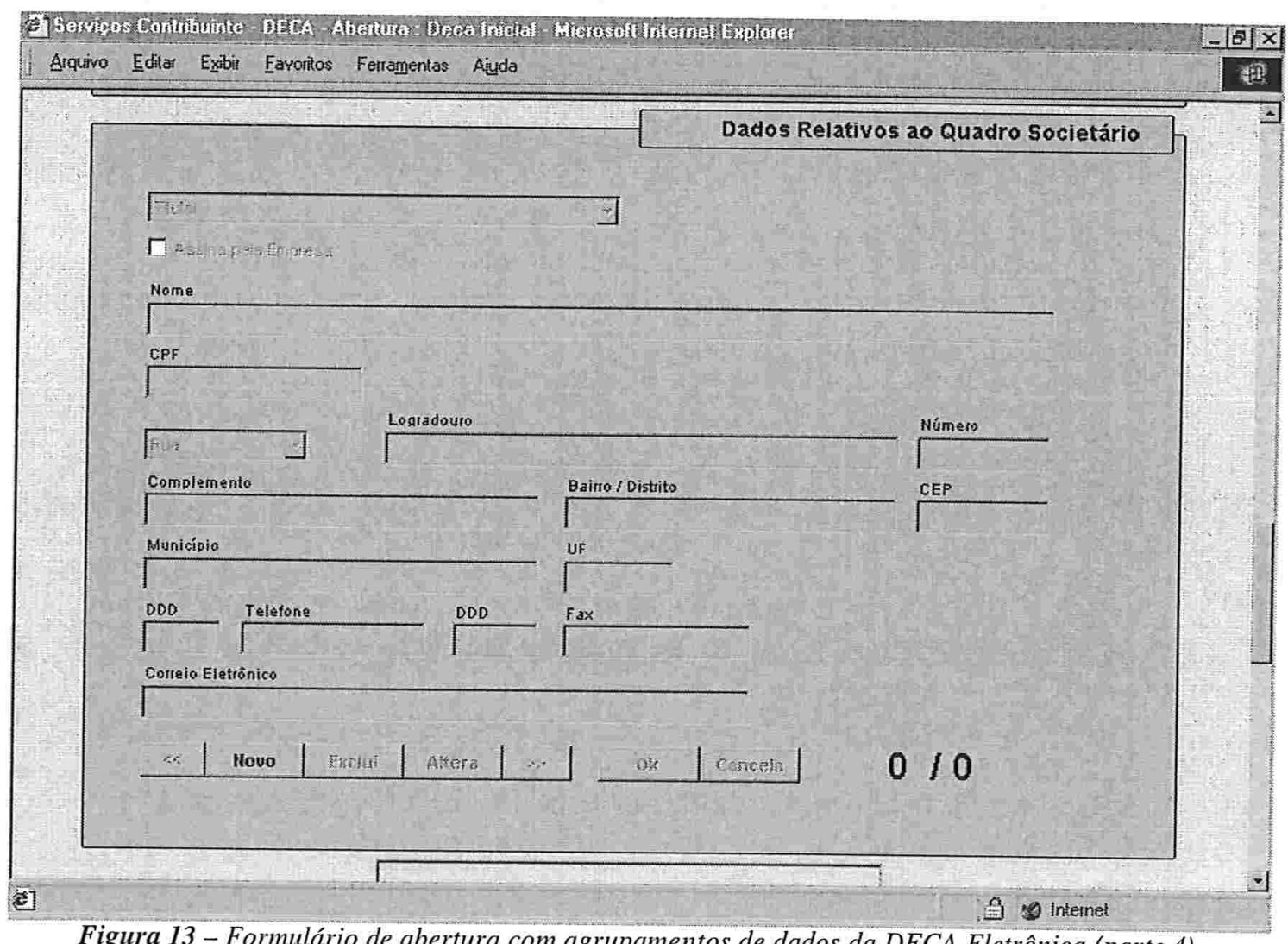

Figura 13 - Formulário de abertura com agrupamentos de dados da DECA Eletrônica (parte 4). 


\section{Alteração: dados cadastrais}

Na tela de alteração abaixo, destacamos o mapeamento dos agrupamentos de dados que são escolhidos e refletem na composição do formulário cadastral de alteração. Os agrupamentos de dados do formulário de alteração são os mesmos apresentados nas figuras $9,10,11$ e 12 .

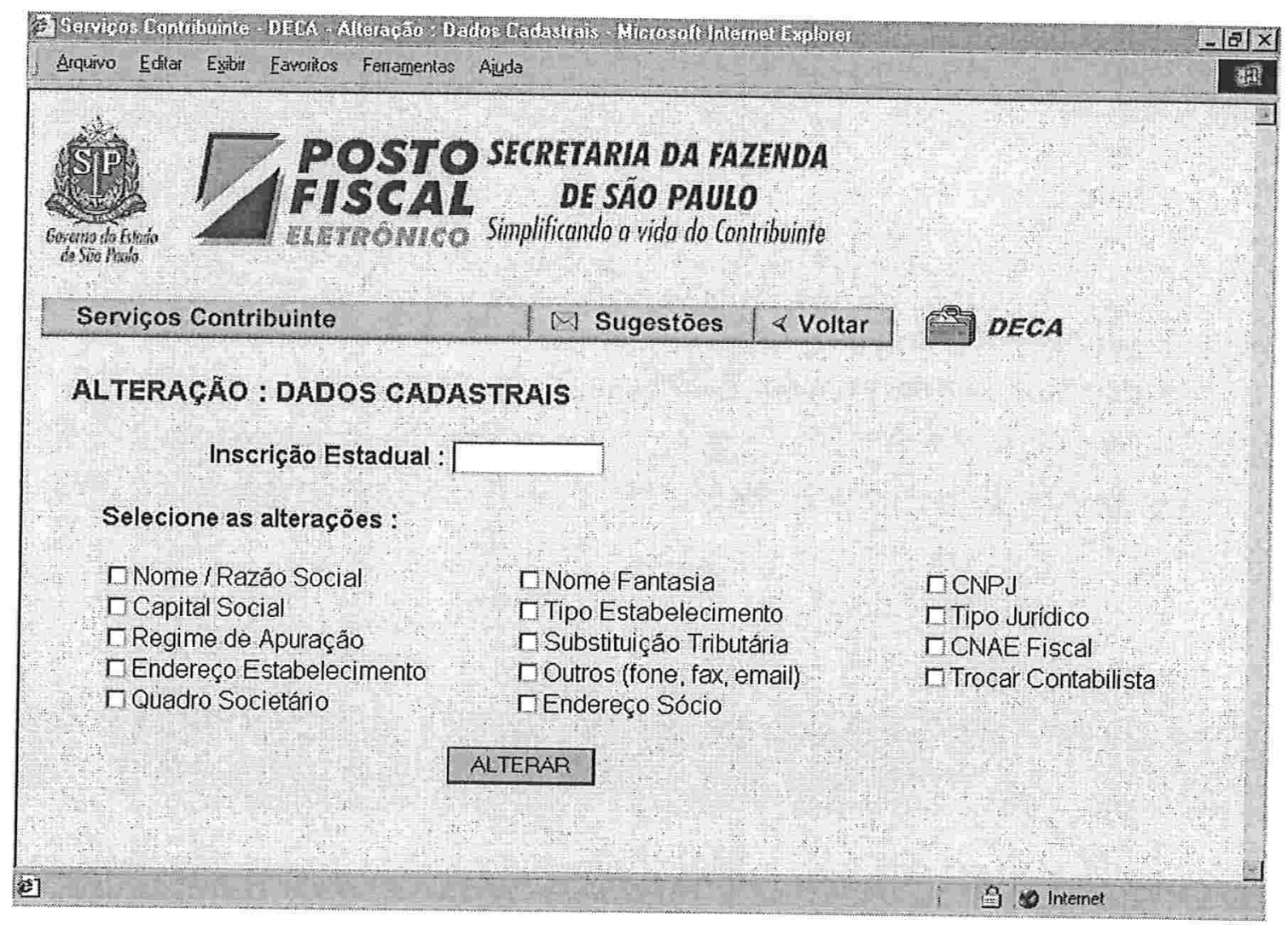

Figura 14 - Tela inicial de alteração de dados cadastrais do sistema DECA Eletrônica. 


\section{Recadastramento: ação complementar}

A operação de recadastramento é uma etapa imposta pela Sefaz-SP aos contribuintes com o intuito de regularizar os dados cadastrais que encontram-se desatualizados. Esse processo foi necessário para permitir a inclusão de dados cadastrais do sistema legado no sistema DECA Eletrônica.

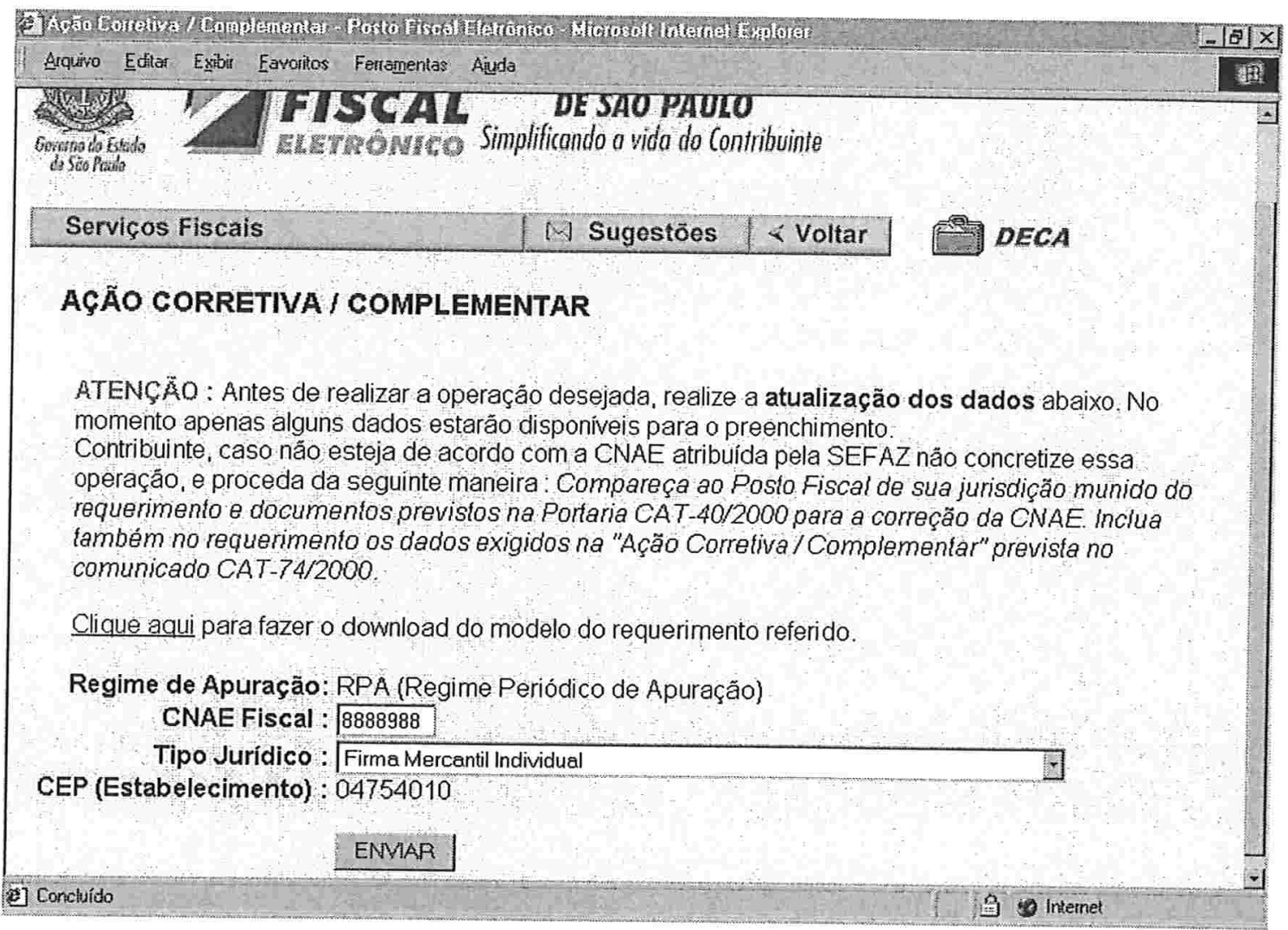

Figura 15 - Tela inicial de recadastramento de dados do sistema DECA Eletrônica. 

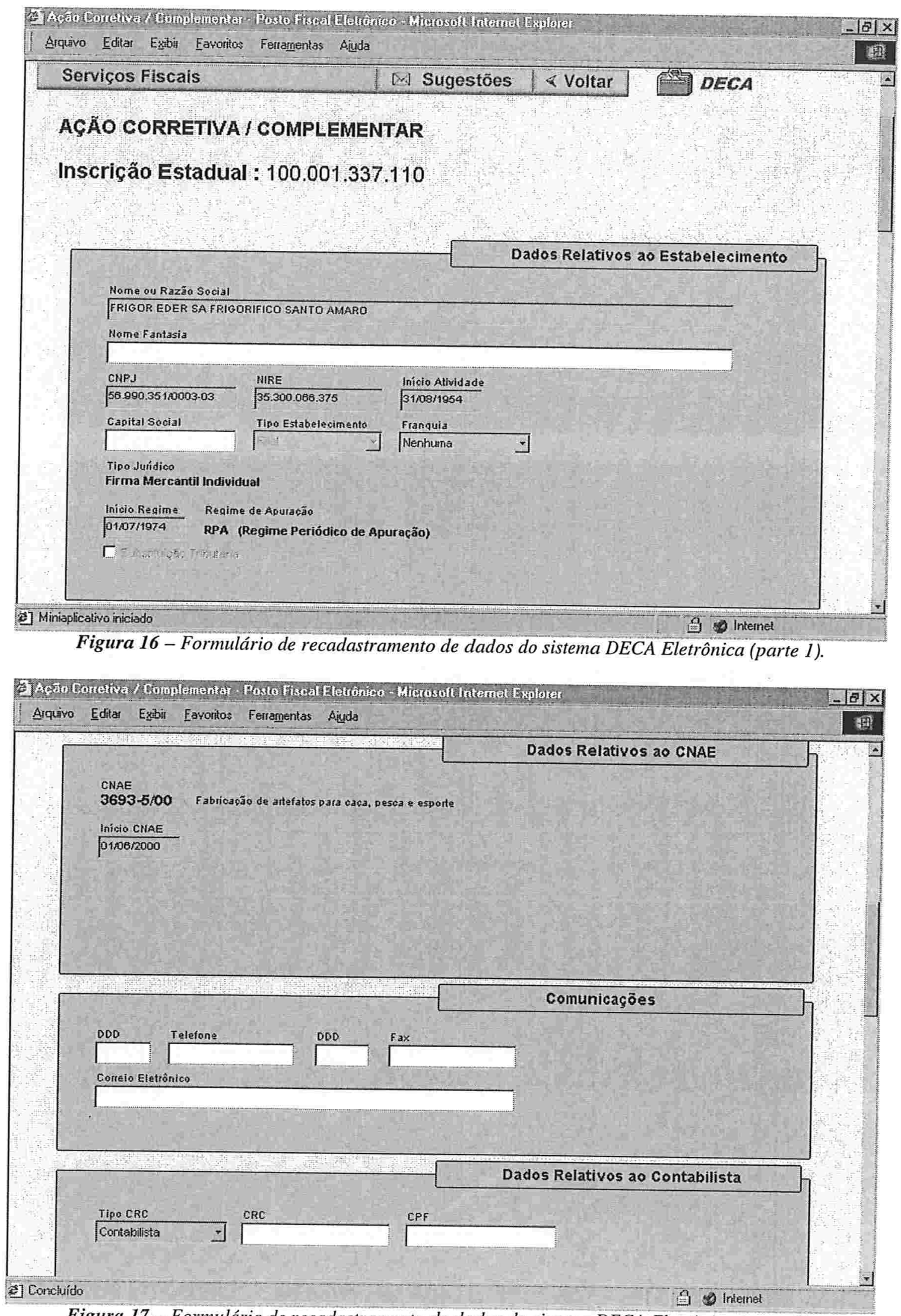

Figura 17 - Formulário de recadastramento de dados do sistema DECA Eletrônica (parte 2). 


\section{Consulta: protocolo DECA}

As interfaces a seguir destacam o acompanhamento das solicitações cadastrais por meio do número do protocolo DECA. Por essas interfaces é possível visualizar as etapas de consistência cadastral envolvidas com as transações realizadas pelos contribuintes, contabilistas e fiscais.

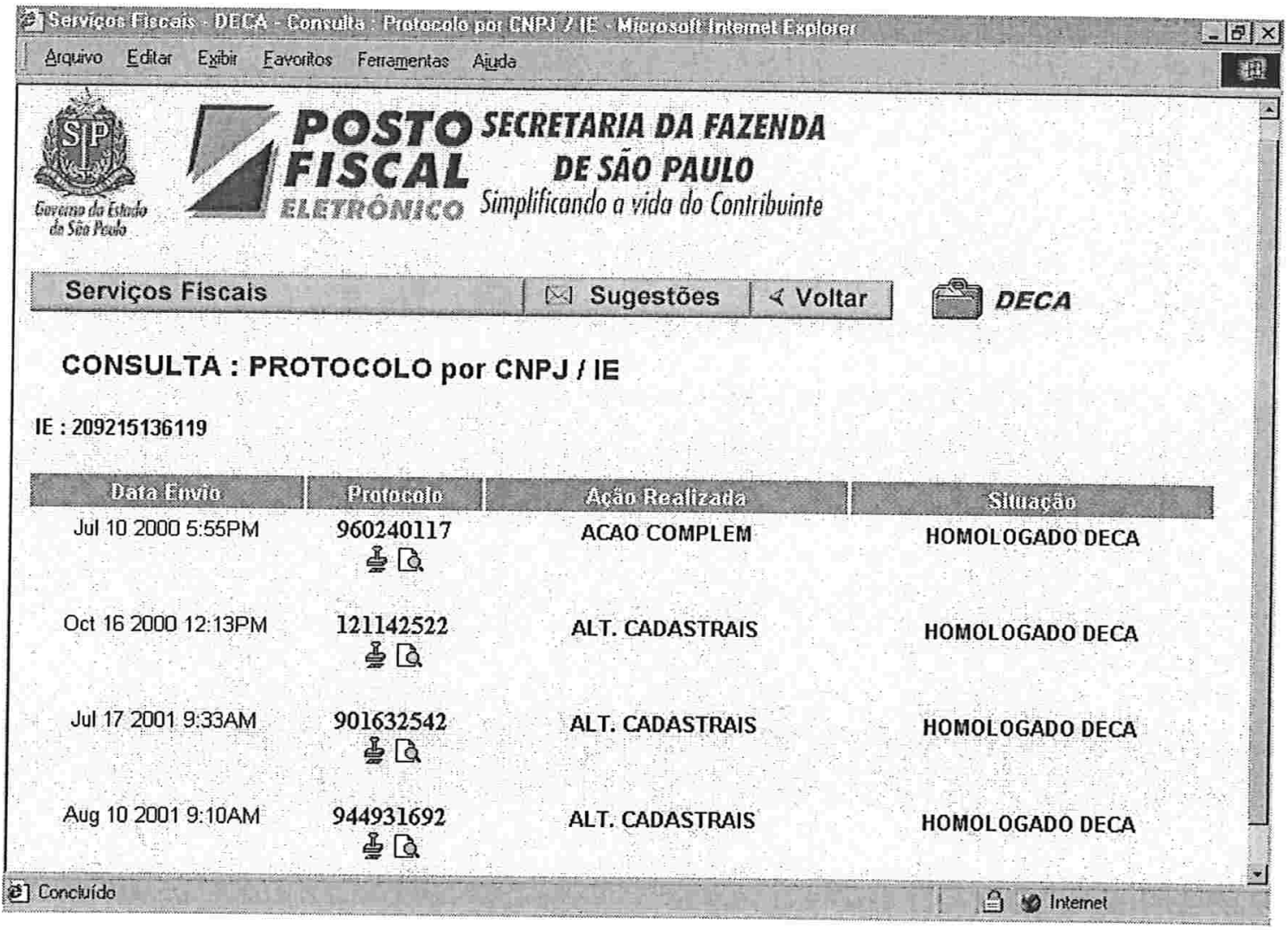

Figura 18 - Consulta de solicitações cadastrais no sistema DECA Eletrônica. 


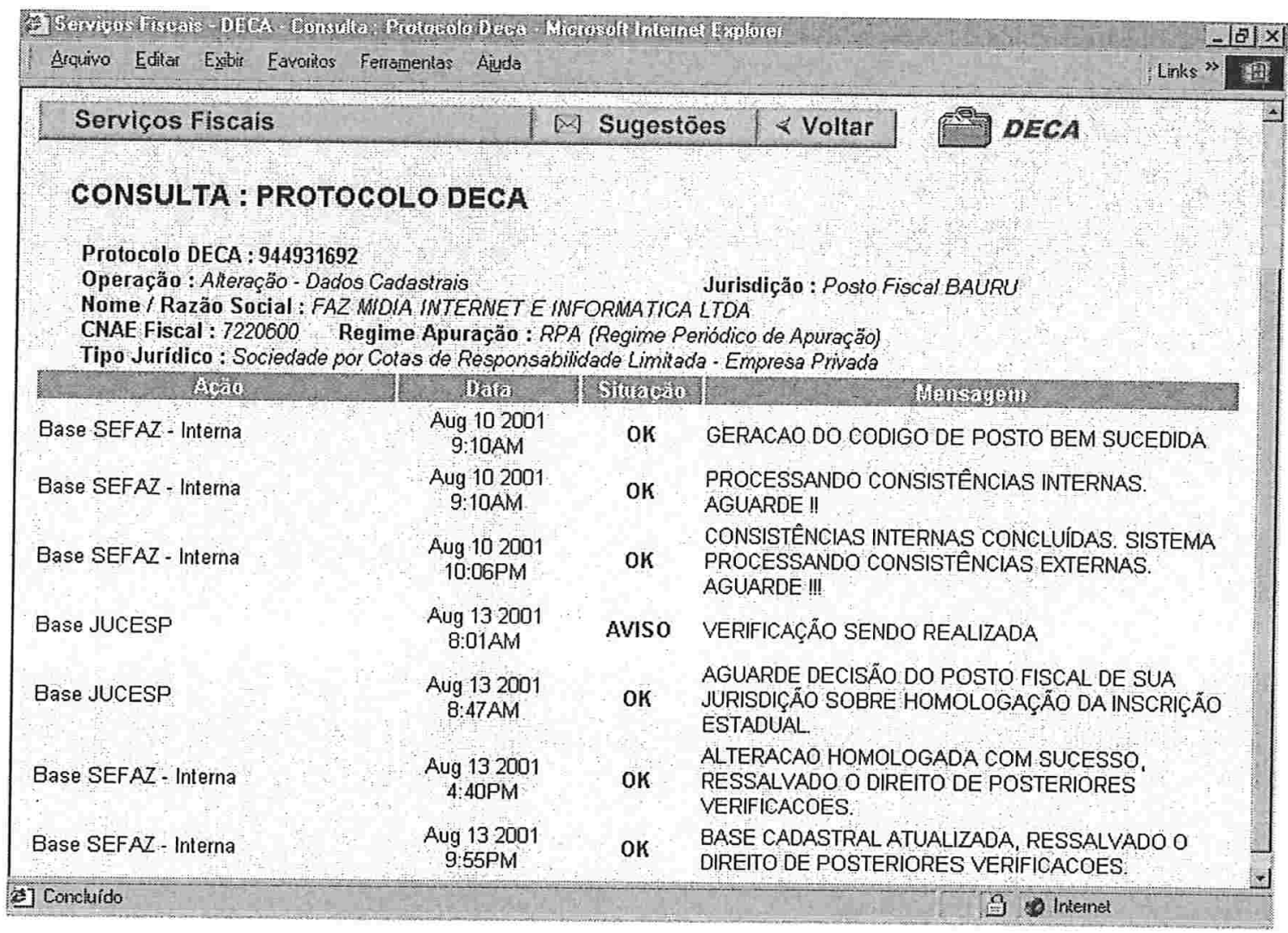

Figura 19 - Detalhamento das consistências cadastrais das solicitações no sistema DECA Eletrônica. 


\section{Apêndice 3 : estruturas cadastrais do sistema DECA Eletrônica}

Apresentamos nesse apêndice algumas tabelas criadas na base de transações tentativas do sistema DECA Eletrônica. O intuito dessa seção é mostrar mais detalhadamente as estruturas cadastrais que recepcionam as transações tentativas. Não trataremos neste tópico as demais tabelas da base de dados.

\begin{tabular}{|ll|}
\hline \multicolumn{2}{|c|}{ logcontrib_pri } \\
\hline pr_protocolo & numeric(10) \\
ie_ie & char(12) \\
dt_data & datetime \\
id_usuario & numeric(10) \\
tp_base & smallint \\
tp_status_ant & char(2) \\
tp_mesg_ant & char(5) \\
tp_status_post & char(2) \\
tp_mesg_post & char(5) \\
da_mensadicional & varchar(255) \\
\hline
\end{tabular}

\begin{tabular}{|c|c|}
\hline \multicolumn{2}{|c|}{ contrib_pri } \\
\hline id_prcontrib_pri & numeric(10) \\
\hline ie_ie & $\operatorname{char}(12)$ \\
\hline np_nomeraz & char(115) \\
\hline nc_fantasia & $\operatorname{char}(60)$ \\
\hline dc_docgen & $\operatorname{char}(20)$ \\
\hline ni_nire & $\operatorname{char}(11)$ \\
\hline dt_inicioativ & datetime \\
\hline cs_capsoc & numeric $(20,2)$ \\
\hline tp_estabelec & smallint \\
\hline tp_franquia & smallint \\
\hline dc_cgcfranq & char(20) \\
\hline tp_juridico & smallint \\
\hline dt_regapur & datetime \\
\hline dt_fimparc & datetime \\
\hline tp_regapu & smallint \\
\hline bl_sat & smallint \\
\hline ca_cnae & $\operatorname{char}(7)$ \\
\hline dt_inicnae & datetime \\
\hline tp_vigilancia & smallint \\
\hline dt_vigilancia & datetime \\
\hline nd_vigilancia & char(20) \\
\hline tp_cetesb & smallint \\
\hline dt_licenca & datetime \\
\hline nd_licenca & char(20) \\
\hline dt_cetesb & datetime \\
\hline pr_cetesb & $\operatorname{char}(8)$ \\
\hline tp_endgen & smallint \\
\hline ce_cep & char(11) \\
\hline tp_logradouro & smallint \\
\hline lo__logradouro & char(40) \\
\hline nu_numero & $\operatorname{char}(6)$ \\
\hline cp_complement & $\operatorname{char}(21)$ \\
\hline ba_baimo & char(20) \\
\hline mu_municipio & char(24) \\
\hline uf_uf & char(2) \\
\hline tp_comprova & smallint \\
\hline $\begin{array}{l}\text { dc_identificacao } \\
\text { di_dddfone }\end{array}$ & $\begin{array}{l}\operatorname{char}(20) \\
\operatorname{char}(3)\end{array}$ \\
\hline nt_numfone & $\begin{array}{l}\operatorname{char}(3) \\
\operatorname{char}(8)\end{array}$ \\
\hline df_dddfax & $\operatorname{char}(3)$ \\
\hline ni_numfax & char $(8)$ \\
\hline em_email & $\operatorname{char}(40)$ \\
\hline va_icms & numeric $(18,2)$ \\
\hline va_prestados & numeric $(18,2)$ \\
\hline cr_contab & char(11) \\
\hline tp_docconta & smallint \\
\hline dc_docconta & char(20) \\
\hline tp_acao & smallint \\
\hline tp_servico & smallint \\
\hline pa_acao & $\operatorname{char}(30)$ \\
\hline tp_consiste & smallint \\
\hline tp_ibm & smallint \\
\hline tp_status & smallint \\
\hline dt_status & datetime \\
\hline tp_classifica & snallint \\
\hline tp_regapu_ant & smallint \\
\hline ju_jucesp & $\operatorname{char}(11)$ \\
\hline ca_cnae_ant & $\operatorname{char}(7)$ \\
\hline ie_anterior & char(12) \\
\hline sid & varchar(30) \\
\hline dt_sistema & datetime \\
\hline dt_acao & datetime \\
\hline nu_processo & $\operatorname{char}(20)$ \\
\hline $\mathrm{cpr1}$ & $\operatorname{char}(4)$ \\
\hline cpr2 & $\operatorname{char}(4)$ \\
\hline cd_posto & $\operatorname{char}(6)$ \\
\hline tp_opreg & smallint \\
\hline tp_motivo & smallint \\
\hline vi_padrao & numeric $(18,2)$ \\
\hline tp_reg_ibm & smallint \\
\hline tp_atividade_aux & smallint \\
\hline dt_atividade_aux & datetime \\
\hline
\end{tabular}

\begin{tabular}{|ll|}
\hline \multicolumn{2}{|c|}{ socio_pri } \\
\hline id_sociobas & numeric(10) \\
id_prcontrib_pri & numeric(10) \\
tp_part & smallint \\
tp_pesso__emp & smallint \\
nc_nome & char(115) \\
tp_docgen & smallint \\
dc_docgen & char(20) \\
dc_rg & char(20) \\
dc_rg_ant & char(20) \\
tp_stu & smallint \\
tp_logradouro & smallint \\
lo_logradouro & char(40) \\
nu_numero & char(6) \\
cp_complement & char(21) \\
ba_bairro & char(20) \\
ce_cep & char(11) \\
mu_municipio & char(24) \\
uf_uf & char(2) \\
df_dddfone & char(3) \\
nf_numfone & char(8) \\
df_dddfax & char(3) \\
nf_numfax & char(8) \\
em_email & char(40) \\
dt_sisema & datetime \\
dt_acao & datetime \\
tp_servico & smallint \\
pa_acao & char(30) \\
b__assina & smallint \\
tp_docgen_ant & smallint \\
dc_docgen_ant & char(20) \\
tp_pais & smallint \\
nd_cpfrep & char(20) \\
\hline & \\
&
\end{tabular}

Figura 20 - Tabelas contrib_pri, socio_pri e logcontrib_pri da base de transações tentativas da DECA Eletrônica. 